Illinois State University

ISU ReD: Research and eData

Theses and Dissertations

$6-24-2020$

\title{
Minor Subjects: Power and Inequity in Children's and Adolescent Literature
}

Wesley Jacques

Illinois State University, wjacques.ilstu@gmail.com

Follow this and additional works at: https://ir.library.illinoisstate.edu/etd

Part of the English Language and Literature Commons

\section{Recommended Citation}

Jacques, Wesley, "Minor Subjects: Power and Inequity in Children's and Adolescent Literature" (2020).

Theses and Dissertations. 1263.

https://ir.library.illinoisstate.edu/etd/1263

This Dissertation is brought to you for free and open access by ISU ReD: Research and eData. It has been accepted for inclusion in Theses and Dissertations by an authorized administrator of ISU ReD: Research and eData. For more information, please contact ISUReD@ilstu.edu. 


\section{MINOR SUBJECTS: POWER AND INEQUITY \\ IN CHILDREN'S AND ADOLESCENT \\ LITERATURE}

\section{WESLEY JACQUES}

\section{Pages}

In this project, I examine theoretical parameters of what has historically been considered American children's and adolescent literature to further complicate its subject matter. The importance of reconsidering subjects is upheld here as key to challenging longstanding cultural and political inequities in the reading and teaching of literature broadly. Nonetheless, as this project contends, children's and adolescent literature as a discipline is uniquely positioned to examine political power and challenge major power structures, not in spite of its presumed minor position in academic and literary discourse, but largely because of it. Thus, what follows is an inquiry into contemporary theories of subjecthood unique to children's literature and culture; a proposed alternative framework, "minor lit"; and an examination of its application in literary analysis and teaching.

KEYWORDS: children; adolescence; political power; intersectionality; inequity; minor lit 


\section{MINOR SUBJECTS: POWER AND INEQUITY}

IN CHILDREN'S AND ADOLESCENT

LITERATURE

WESLEY JACQUES

A Dissertation Submitted in Partial

Fulfillment of the Requirements

for the Degree of

DOCTOR OF PHILOSOPHY

Department of English

ILLINOIS STATE UNIVERSITY 
(C) 2020 Wesley Jacques 
MINOR SUBJECTS: POWER AND INEQUITY

IN CHILDREN'S AND ADOLESCENT

LITERATURE

WESLEY JACQUES

COMMITTEE MEMBERS:

Roberta Trites, Chair

Karen Coats

Ricardo Cruz 


\section{ACKNOWLEDGMENTS}

I've had brilliant scholars, educators, and advisors throughout my academic career, and I thank them tremendously for their support in this process. Roberta Trites, Karen Coats, and Ricardo Cruz deserve my tremendous gratitude for their contributions to this ultimately collaborative endeavor, and their thoughtful fingerprints can hopefully be read throughout the subsequent pages. Still, I also have a young nephew and two young nieces. Each has continually taught me everything in the world I've needed to know about children's literature and culture. They are undoubtedly present in these pages as well.

W. J. 


\section{CONTENTS}

Page

ACKNOWLEDGMENTS

$\begin{array}{ll}\text { INTRODUCTION } & 1\end{array}$

CHAPTER I: ON SUBJECTS 11

$\begin{array}{ll}\text { Syndicated Subjects } & 13\end{array}$

$\begin{array}{ll}\text { Desiring Subjects } & 23\end{array}$

$\begin{array}{ll}\text { Mystery Subjects } & 35\end{array}$

CHAPTER II: ON POWER, MINORS, AND MINOR LIT 41

$\begin{array}{ll}\text { On Territory and Power } & 45\end{array}$

On Becoming Minors and Minorities $\quad 48$

On a Minor Lit's (Im)Possibilities $\quad 54$

$\begin{array}{ll}\text { The Body of Minor Lit } & 62\end{array}$

CHAPTER III: ON SEX, FAMILY, AND DREAMING 65

$\begin{array}{ll}\text { Pecola’s Pleasure } & 68\end{array}$

$\begin{array}{ll}\text { Daughters and Mothers } & 76\end{array}$

$\begin{array}{ll}\text { Jackie's Dreams } & 87\end{array}$

$\begin{array}{ll}\text { Minor Conclusions } & 98\end{array}$

$\begin{array}{ll}\text { CHAPTER IV: ON TEACHING MINOR FOLK } & 100\end{array}$

$\begin{array}{ll}\text { Why We Tell This Story } & 102\end{array}$

Why We Tell This Story to Some Kids and Not Others 108

How to Tell This Story to Everyone $\quad 121$

How to Tell the Ending 132 


\section{INTRODUCTION}

Western children's literature as it is traditionally disseminated — in classrooms and local libraries, within communities and at bedtimes, and via global media - is hegemonic in its presentation of the subject of childhood. That is to say, inherent to the workings of children's and adolescent literature are varied structures of cultural domination, which, as affirmed by Marxist philosopher Antonio Gramsci (1971), illustrate the "intellectual and moral authority" of the powerful and oppressive (Selections 212). In essence, children's and adolescent literature has a power problem. And a number of children's literary scholars have brought attention to this problem over the years. When Perry Nodelman (2008) writes that children's literature "might characteristically and even inherently and unavoidably imply" a dual audience of children as well as adults, he is drawing attention to a proverbial territorial dispute between the young intended audiences and the dominant adult epistemologies that inform these texts (Hidden 206). Nodelman recognizes “the field of children's literature — its production and consumption_-[as] so overwhelmingly occupied by adults," it yields "a complex repertoire of unspoken but implied adult knowledge," or, as he coins it, a "hidden adult," which lurks in these ostensibly childfriendly texts like "a shadow, an unconscious" (206-07).

Likewise, after scrutinizing the role of parental, narrative, and ideological authority in adolescent novels, Roberta Seelinger Trites (1998) determines that "adolescent literature seems to delegitimize adolescents, insisting that "adolescentness," especially immaturity, is unacceptable, even though the surface intention of most YA novels is ostensibly to legitimize adolescence" (Disturbing 83). Trites identifies this textual tension as paradoxical, simultaneously delineating the cultural parameters of adolescence while designating it as not only untenable, but inappropriate. "Since so many adolescent novels," Trites continues, "contain parents who must 
be rebelled against and adult narrators who are the source of the text's often repressive ideological wisdom, the genre does seem to communicate to teenagers that authority is not and should not be theirs" (83). The adolescent subjects of these texts are then plainly subjugated by presumably adult, but undeniably powerful forces—yet this subjugation is seemingly inextricable from the construction of those subjects.

In the context of the young adult novel, in particular, Mike Cadden (2000) questions the ethics of this power discrepancy, calling out the irony in narratives that attempt to reconcile the uneven voices of adults and children. "Novels constructed by adults," he writes, "to simulate an authentic adolescent's voice are inherently ironic because the so-called adolescent voice is never—and can never be — truly authentic" ("The Irony" 146). This irony is potentially ameliorated, according to Cadden, by a "double-voiced" narrative, or text that "represents voices as equal and provides alternative interpretations that offer, in their aggregate, no single and final answer for the reader" (147). Still, while Cadden eventually lauds adult-penned but young adultaimed texts that successfully make their ironies visible to young readers, the notion of irony itself, an obfuscation or misdirection of meaning, speaks again to the complexities of children's and adolescent literature and the meaningful imbalance of power embedded in these texts.

Similarly, when Maria Nikolajeva (2009) calls upon a "heterological approach to juvenile literature," she considers narrative alterity—or the ways texts tend to ascribe other status- to examine power discrepancies between adult creators and implied young readers, establishing eventually a theory of aetonormativity, which reifies adult normativity at the expense of child subjects ("Theory" 13). In this, Nikolajeva recognizes that "nowhere else are power structures as visible as in children's literature, that refined instrument used for centuries to educate, socialize and oppress a particular social group," so in theorizing this instrument, we gain insight to the 
workings of power broadly (Power 8). "Aetonormativity," she adds, "does not operate in a vacuum, but is intertwined with other heterological structures, including gender, ethnicity and class" (203).

Collectively, these critical explorations of power in children's and adolescent literature, as well as the various societal structures Nikolajeva acknowledges as entwined with considerations of youth identity, allow for clearer recognition of the machinations of cultural hegemony in children's literature, i.e., the ways in which domination-hidden, paradoxical, ironic, or aetonormative - is inherent to the literary subjectivization of childhood and adolescence. This project contends that scrutiny of this hegemony is especially valuable to the field of children's and adolescent literature because the hegemonic subjects therein are negotiated through the dominance of neoliberalism and white supremacy. That is to say, for children's and adolescent literature to progress meaningfully toward inclusion and equity, freeing itself of the oppressive weight of global capitalism and systemic discrimination, hegemony must be challenged directly. To effectively execute this challenge, this dissertation proposes a) a reconfiguration of how scholars and academic practitioners think about and deploy texts that engage the subjects of childhood and adolescence; and b) a new theoretical framework that reveals the potentially radical politic of a children's literature.

Many critical perspectives contribute significantly to this reconfiguration and the corresponding theoretical framework being proffered by this project. In addition to the aforementioned—Nodelman, Trites, Cadden, and Nikolajeva—Nancy Tolson (2008) notably recasts Black children's literature within the Black folk art tradition, particularly the blues aesthetic, to reveal how texts intended for child audiences can engage thoughtfully and productively with discourses of political power and domination. In the unique instance of Black 
children's literature historically, Tolson writes, "Some Black authors, educators and historians began to realize that for a culture to progress so must the literature that will influence the culture's future" (Black 17). That is, to combat the centuries-old proliferation of "negative of images of Blacks and Black culture within children's books"-which Tolson establishes as "detrimental [...] for both Black and white children"—artists, academic practitioners, and communities have been able to model a reconfiguration of children's literature and its corresponding praxis that is immensely valuable to this dissertation.

This project calls upon the concepts afforded by Marxism to interpret children's and adolescent literature with regard to its productions, history, and socioeconomic structures. Exploring the ways these elements relate to one another-how, for example, early-twentieth century publisher Edward Stratemeyer's production of a number of series fiction properties, including Nancy Drew in 1930, relied on emerging perspectives of the American child at the time while also establishing standards and forms for continued cultural reproduction of American childhood nearly a century later - unearths the material (in the Marxian sense) of children's literature and its subjects. And in that this project aims to challenge this material, Marxism—its radical politics, its unique materialism—offers a compelling vocabulary of critique and analysis.

Likewise, in addition to Marxist scholars, such as Louis Althusser, the structural and post-structural theories of Jacques Lacan, Gilles Deleuze and Félix Guattari, among others, allow for constructive understanding of subjecthood in the context of language, desire, and ideology. What it means to speak of the subjects of a text or the subjects of childhood and adolescence or, even, real-life child subjects is of great import to this project, so exploring subjectivity itself, although understandably difficult at times, is surely worthwhile. In evoking a Lacanian interpretation, for example, Karen S. Coats (2004) describes how subjectivity manifests within 
systems of representation, like a baby recognizing himself in a mirror image, but, nonetheless, "it is still the Other's system, something external to him that he has taken on" (Looking Glasses 3). In this, Coats recognizes some of the inherent complexities of subjecthood, that even the word "has resonances of both agency and subservience," as well as conflicting grammatical, academic, and legal connotations, to say the least (3). In her work, Coats advises "to hold these contradictions in unresolved ambiguity," and goes on to use children's literature, especially Lewis Carroll's Through the Looking Glass, and What Alice Found There (1872) and Alice herself, "to open our way into a notoriously difficult theory of the subject" $(3,79)$. This theory, especially attuned to children's literature as a particularly significant and desirous space, is effectively able to present subjectivity as inextricable from the Lacanian mirrors, literary looking glasses, or other dominant psychic structures that construct it. Still, this construction or interpellation cannot be assessed apolitically because these structures are always already political, just as Althusser (1971) famously notes that "you and I are always already subjects," always already enmeshed in the ideological (and repressive) forces that constitute our subjectivity ("Ideology" 176).

Gilles Deleuze and Félix Guattari's 1974 conception of minor literature offers the necessary reconciliation of Lacanian structures (e.g., desirous subjects and the orders of the Imaginary, the Symbolic, and the Other) and the material politics inherent to Western literature, history, and culture. For Deleuze and Guattari, a minor literature is "that which a minority constructs within a major language" (Kafka 16). In that Deleuze and Guattari detail thoroughly what constitutes the minority position, in adapting this use of minor literature for this project, it must be acknowledged that their work also speaks directly to what constitutes the dominant majority-i.e., power, especially in regards to language, politics, and valuation. And in that the 
goal of this project is to examine this power in the context of children's and adolescent literature, building a theoretical framework for these texts atop minor literature, as well as the number of aforementioned critical theories, commits this project to employing a necessarily robust and challenging network of ideas, because this particular corner of the literary landscape is necessarily robust and challenging and houses an immense potential for scholarship and social justice.

Nonetheless, engaging with both children's literary works and these varied critical theories definitely requires acknowledgement of what Barbara Christian (1987) deftly identifies as "the race for theory," or the contemporary trend towards "reinvent[ing] the meaning of theory" as a commodity to be reproduced and disseminated ad nauseam by a dominant few, while simultaneously intimidating and devaluing particular voices and intellectual work, especially those of Black women ("The Race" 51)—in other words, Christian's own, "academic hegemony" (53). So for this project to be effective in establishing a theoretical framework capable of challenging hegemony in children's literature, the approach itself must be inclusive of and deferential to sources of theory and theoretical work often excluded from serious scholarly consideration.

"For people of color have always theorized," Christian writes, "but in forms quite different from the Western form of abstract logic" (52). She continues:

And I am inclined to say that our theorizing (and I intentionally use the verb rather than the noun) is often in narrative forms, in the stories we create, in riddles and proverbs, in the play with language, since dynamic rather than fixed ideas seem more to our liking. How else have we managed to survive with such spiritedness the assault on our bodies, social institutions, countries, our very humanity? (52) 
With these factors brought to light, it becomes increasingly difficult to rely squarely on traditional academic epistemologies, which distinguish sharply between knowledges derived from storytelling and riddles, for example, and those from a systemic reverence to dominant voices, which yields fragmentation on the level of meaning making and inequity on the level of discourse. This fragmentation is discernible in how, according to Christian, "[literary] works (a word which evokes labor) have become texts," and how the work of teaching and writing in response to literature has "become subordinated to [the] primary thrust" of creating theory (52). Similarly, Patricia Hill Collins (1996) explores the prejudice inherent to this form of knowledge pursuit when she argues that, even after unmistakable advances, "black women's texts are still much more welcomed than black women ourselves" in scholarly spaces, drawing additional attention to how new, more inclusive frameworks of knowing and thinking have become increasingly necessary to address inequity ("What's in a Name?" 9). In the context of children's literature, this inequity is especially relevant because the narrative forms and language play of the genre, although more representative today of diverse voices than in the past, remain so frequently considered less meaningful than and wholly distinct from the work of so-called intellectuals. But, as this dissertation will contend, to grapple with the works of Toni Morrison, Jacqueline Woodson, and Sherri L. Smith, to name just a few significant Black female authors, as if their stories and verse and fictions aren't also theoretically productive would be a disservice to the field. The theoretical framework being established by this project cannot exist without challenging the limitations of Theory itself while also reclaiming the theorizing potential of works of children's and adolescent literature. Black feminist thought, as Collins coins it—but as Angela Yvonne Davis, bell hooks, Barbara Christian, and so many others contribute to its efficacy — is indispensible to the radical makeup of this proposed framework. 
The arguments of this project are three-fold and simple: First, representation and inclusion matter in children's literature but are impossible to address effectively without disrupting hegemony and its commitments to neoliberal and white supremacist structures. Second, the unique power dynamics of children's literature, although illustrative of its hegemonic utility, are also potentially subversive and radical. Last, the theoretical framework of a minor literature offers a productive path toward challenging this hegemony, maintaining the potential for subversion, and promoting radical inclusion.

On some basic level the subjects of children's and adolescent literature are children and adolescents, but the phenomena and discourse surrounding subjectivization are often more complex. In Chapter 1, I explore the aforementioned "unresolved ambiguity," as Coats puts it, which allows children's literature to concurrently construct its audience as subjects while presenting readers with varying, often conflicting, subjects for their consumption. Through a structural interpretation of the subject, this chapter aims to reveal the ways language, desire, ideology are indispensable to the workings of children's literature, and, likewise, these particular structures represent well the great power of children's literature that is all too often used to subjugate by way of cultural hegemony. I will use texts from The Outdoor Girl mystery series (1913) to the Pretty Little Liars series (2006) — purposefully bookending nearly a century of cultural progression.

The second chapter invokes the work of Deleuze and Guattari to suggest that, perhaps, some literature can be interpreted through alternative frameworks that draw attention to and even challenge cultural hegemony. In this chapter, I will reframe their term "minor literature" as "minor lit" to accommodate the unique characteristics of literature that center childhood and adolescence in ways that complicate conventional readings. The Bluest Eye (1970) to The 
Catcher in the Rye (1951) to Narrative of the Life of Frederick Douglass, an American Slave (1845) are called upon as examples to support the definition of minor lit presented. Additionally, terms like "minor" and "minority" are carefully redefined within this new framework without necessarily shedding the more prevalent, largely racial connotations. Finally, this chapter emphasizes the project's overall emphasis on inclusion by defining inclusion in terms of race, but also texts and interpretative modes.

My third chapter is squarely concerned with the ways Black women have used literary subversion as means of political and scholarly action. Calling on some of the aforementioned arguments presented by Barbara Christian in "The Race to Theory" (1987), where she writes extensively about the devaluing of Black women's ideas in academia as well as the intimidation and exclusion of the women who expound them, this chapter hopes to deploy the newly defined minor lit framework to recover and reclaim some of the theoretical contributions of authors such as Toni Morrison (The Bluest Eye (1970) and Sula (1973)) and Jacqueline Woodson (Brown Girl Dreaming (2014)). The ways such authors theorize and critique in plain sight but nestled within the supposedly "safe" confines of African-American and/or children's literature is, this chapter will ultimately argue, truly subversive of the ways academic institutions and literary channels function. This subversive potential is unique to literatures that invoke childhood and adolescence but is optimized by a reconfiguration toward minor lit.

The final chapter furthers the work of what preceded it by considering texts that are often excluded from conventional discourses of children's literature despite being largely focused on the subject of children and adolescence, namely lynching narratives in the United States. The narrative function of extra-judicial murder and its spectacle will be explored in detail with special attention to how narratives, such as Emmett Till's 1955 murder in Mississippi, 
disseminate as de facto folktales for Black-American children but are often censored, neglected, and unrecognized in academic settings. This exclusion suggests that these narratives-and others that negotiate race, sex, and poverty in stark, earnest terms - critically challenge hegemony in significant ways. More recently, there has certainly been an influx of examples of children's and adolescent texts that engage with these narratives of violence, and this chapter will certainly offer readings of their efficacy. Overall, the robust theoretical framework established by this project up to this point — with minor lit as its named centerpiece — will be put to the test of reclaiming these narratives in terms of radical scholarship and pedagogical praxis. Thus, what follows is an inquiry into contemporary theories of subjecthood unique to children's literature and culture; a proposed alternative framework, "minor lit"; and an examination of its application in literary analysis and teaching. 


\section{CHAPTER I: ON SUBJECTS}

Four girls were walking down an elm-shaded street. Four girls, walking two by two, their arms waist-encircling, their voices mingling in rapid talk, punctuated with rippling laughter — and, now and then, as their happy spirits fairly bubbled and overflowed, breaking into a few waltz steps to the melody of a dreamy song hummed by one of their number.

-- Laura Lee Hope, The Outdoor Girls of Deepdale

They all loved Ali to death, but they sometimes hated her too- - for bossing them around and for the spell she'd cast on them. Sometimes in Ali's presence, they didn't feel real, exactly. They felt kind of like dolls, with Ali arranging their every move. Each of them wished that, just once, she had the strength to tell Ali no.

-- Sara Shepard, Pretty Little Liars

The subject of children's and adolescent literature may seem, on its surface, self-evident in depictions of young people on idyllic, tree-lined strolls or coping with the melodrama of a mean girl. Yet reconsidering the complex subject(s) of childhood and adolescence is of utmost importance for scholars' ability to understand the issues of power inherent in the literatures that bear their names. But to even employ the word "subject" demands engagement with its meaning in domains as divergent as — among others — the linguistic (grammatical subjects), the academic (subjects of inquiry), the metaphysical (subjects as opposed to objects), and the political (subjects of a dominion). Scholars from Descartes to Freud have had multiple debates, as well as offering both conflicting and discrete perspectives. Yet this multiplicity is undeniably a strength. 
It follows then that the subject of children's and adolescent literature-and how literature informs our understanding of children and adolescent subjects - cannot be only one distinct thing. As philosopher Peter Lamarque explores in his varied Fictional Points of View, effectively critiquing literature involves grappling with interwoven logics, tensions, relations within an authored world, as well as those complexities in the real world shared by authors and readers. That is, according to Lamarque, "there is the 'internal' view of participants in those worlds, where the surroundings are not fictional but real," as exemplified in this chapter's epigraphs, in which the idyllic outings of the Outdoor Girls and the tumultuous relationships of the Pretty Little Liars are genuine and palpable, "and the 'external' view of those (like us) outside looking in, where the worlds are not real but fictional," where cultural context, authorship, ideology are indivisible from these invented stories, these made-up characters, their subjects (2). Nevertheless,, while Lamarque rightfully suggests, "we must see fiction as an important, even indispensable, vehicle for exploring human concerns," the relationships between literary subjects and real-life subjects, human subjects and subjects of study, discursive subjects and material ones are productively complicated. Thus, to determine the complicated subjects of the first volume of a notable Stratemeyer series, The Outdoor Girls of Deepdale (1913) or a popular contemporary multimedia counterpart, Pretty Little Liars (2006), is to produce an invaluable picture of subjecthood (with special attention to girlhood) in the context of children's and adolescent literature. While placing these two series in dialogue with one another offers interesting literary contrasts over the span of a century, their similarities offer a genealogy of American children's and adolescent literature and will establish the historical scope of this project as a whole. 


\section{Syndicated Subjects}

At the beginning of the twentieth century, the category of juvenile fiction-now considered a precursor to contemporary children's and adolescent categories-featured characters written and marketed broadly to school-age children and owed much of its emerging prominence to Edward Stratemeyer and his publishing "Syndicate." Starting with the publication of the Rover Boys novels in 1899, Stratemeyer went on to popularize the series fiction conventions that remain widespread in books for young readers and produced seminal adolescent icons such as the Hardy Boys and Nancy Drew, which established publishing methods and narrative trends that persist in contemporary children's and adolescent literature. "Between 1900 and 1930," according to journalist Bruce Watson, "he turned his uncanny sense of young readers' tastes into an action and adventure factory that churned out more than 1,300 juvenile novels in 125 different series written under scores of distinct and slightly stilted pseudonyms" (“Tom Swift” 52). Today, much of what we recognize as children’s and adolescent literature, especially young adult (YA) fiction, shares a lineage with these juvenile titles, which creates an opportunity for us to advance our understanding of how child and adolescent subjects exist in these under-investigated, hundred-year-old books.

With regard to the subject of the American child and its development, "[h]ow character was formed had been a matter of great interest since the 1890s," writes historian Peter Soderbergh in "The Stratemeyer Strain: Educators and the Juvenile Series Book, 1900-1973" (864). Soderbergh identifies parents, teachers, librarians, and social reformers as key to the discursive cultivation of adolescent subjects or, borrowing from late-nineteenth early-twentieth century statesman Anthony Comstock, the "finest fruits of civilization" (864). But although differences of perspective were prevalent, "no true expert on boyhood and girlhood doubted that 
what a child read was a vital key to what he became" (864). It thus remains no surprise that, like the relatively inexpensive and regularly derided "dime novel" of late nineteenth century fame or the "lewd' magazines and spicy gazettes" materializing at the turn of the century, concerned social critics quickly turned to what children were reading to effectively theorize them into a literary existence and, essentially, to explain the all too common refrain of what's wrong with young people these days (865). And what exactly were these supposedly misguided young people of the 1900s reading? Stratemeyer titles. A lot of them.

1913's The Outdoor Girls of Deepdale, the first installment of a once tremendously popular series produced by the Syndicate under the pseudonym Laura Lee Hope, offers an ideal example of what droves of these young readers were reading. In its attractive offering of adventuring teenagers marketed towards teenagers and its position historically at the onset of serious considerations of adolescent subjecthood by not only savvy entrepreneurs like Stratemeyer but also American culture at large, a close examination of this proto-YA novel reveals an ideological construction of adolescence-feminine adolescence in particular-at the purposeful hands of adult creators. While the Stratemeyer books are an early example of ideological construction of adolescence by adults, the later narratives in the Pretty Little Liars franchise demonstrate an increased tension between what adults desire adolescence to be and the desire emerging from adolescence itself. The construction of adolescence in Pretty Little Liars is no less ideological than that displayed in The Outdoor Girls, but the more recent series does have components that aren't as adult-centered as the earlier construction of adolescence is.

As in much of adolescent literature, even to this day, an uneven relationship exists between the voice of the adolescent characters and the third-person narrator's decidedly adult voice. With regard to contemporary YA novels, children's literature theorist Mike Cadden 
suggests that novels are responsible for creating "double-voiced discourse," an ethical balance in the narrative that allows "two or more ideological positions [to] share the text without any one being in obvious control" ("Irony" 147). The double-voiced-ness of a text relies on its ability to present readers with alternative interpretations, or the tools to find these alternatives themselves, to the statements it makes. For Cadden, these questions of what statements are voiced, how, and by whom represent the inherent "irony" in adult authors, editors, and publishers like Stratemeyer attempting to "simulate an authentic adolescent voice," the voice of an authentic adolescent subject (146). Likewise, attention to these questions aids in uncovering the ideological implications of The Outdoor Girls of Deepdale and, accordingly, the complexities of its constructed adolescent subject.

To examine the ethics of an adult-centered construction of adolescence, we can consider first the narrative structure of The Outdoor Girls of Deepdale. The full title continues, with a rather protracted flourish, Or, Camping and Tramping for Fun and Health, which hints both at the sensibilities of the time and Stratemeyer's overt attempt to appeal to young, fun- and healthoriented readers. Unlike the apparent abundance of first-person narration in today's YA novels but markedly similar to many of the other proto-YA texts, The Outdoor Girls of Deepdale is written in third-person narration that furthers this appeal by emulating a seemingly authoritative storyteller. As the girls begin their journey, planning and organizing their camping and tramping club in the quaint, fictional upstate New York town of Deepdale, a third-person narrator closely follows their activity, occasionally providing pointed commentary. It is through this narrator's voice the reader is introduced to the "four girls, walking two by two, their arms waist-encircling, their voices mingling in rapid talk, punctuated with rippling laughter" (Hope 6). Although the third-person narration gives way to the voices of the four girls in the dialogue-heavy writing 
style of the series, it is generally through this third-person perspective that readers come to see each of the girls and the world they inhabit. The text presents Mollie Billette as temperamental, Grace Ford as a chocolate lover, and Betty Nelson as quick with a motivational speech or assertive statement, but the narrator-not a character-interjects with the description of Betty as "the tallest of the quartette, a stately, fair girl with wonderful braids of hair on which the sunshine seemed to like to linger" or "full of life and vigor [and] always ready to assume the leadership in whatever of fun or work was at hand" (Hope 7, 29). Thus, it is the adult-sounding voice of the narrator that ultimately frames how these young characters are constructed.

The last of the protagonists to be introduced by the narrator is Amy Stonington, who first appears to readers with discernible reservations to opening up the camping and tramping club to other members:

"I think four is a nice number," spoke Amy. She was rather shy, and not given to making new friends.

"We four—no more!" declaimed Mollie. "Suppose we do limit it to four, Betty?"

"Well, we can talk of that later. And I do so want to talk of it. [...]" (11) In a move evocative of Cadden's double-voice, the novel engages young readers with both the voice of adolescent characters and the voice of an observant narrator to provide fuller context. Amy's introversion and misgivings about social interaction as well as Betty's accepted leadership position within the group and ability to assuage these concerns are plot points that both the narrator and the dialogue collaboratively present to the reader. Still, as the novel delves further into exploring characterizations, explicit statements about adolescence and femininity become less aligned. 
The narrator's descriptions of the Deepdale girls range from supplemental of the perspectives of the characters to wholly autonomous judgments. The former consists of statements of a personal nature, often representing how ideology affects self-perception. For example, the narrator asserts, "The other girls envied Grace her hair-especially Mollie, who was a decided brunette" (29). The latter consists of judgments from a societal perspective, offered in kind as authoritative statements of early-twentieth century ideology. A prime example is as follows:

I hope I may be permitted to insert here a little descriptive matter that will, perhaps, give the reader a clearer understanding of the characters of this story. [...] Betty was about sixteen years old. She was not exactly what one would call "pretty"that is, at first glance. More likely she would have been spoken of as "good-looking." At least by the boys. And certainly Betty was good to look upon. (28)

Noticeably, the narrator asserts a judgment about Betty, about feminine beauty, about objectivity, and about who should be considered "pretty" at "first glance," which relies on extra-textual ideals. "Her face showed her character," the narrator continues in the same passage, "There was a calm thoughtfulness about it that suggested strength of mind, and yet it was not the type of face called 'strong"' (28). A distinction between prettiness and character is implied, essentially between Grace, the conventional beauty, and Betty, the strong leader. The thoughtful girls aren't the pretty ones. Likewise, being pretty in appearance precludes a strong mind. These statements are some of the many that indicate an ideological positioning of these young girls and a corresponding construction of young feminine subjects.

What must also be addressed is the implication that these judgments are valid largely because "the boys" share this perspective. Political and social dominance by men establishes the 
patriarchy playing a pivotal role in constructing the adolescent characters of the novel, both boys and girls. It follows then that the dual voices of this novel, the four adolescent characters and the narrator, run parallel to the real-life emergence of an adolescent voice and the authoritative voice of a patriarchal society with very specific curtailments for young girls.

As the novel progresses, the characters of The Outdoor Girls of Deepdale internalize the ideological statements presented by the male-created narrator. Grace is identified as a pretty girl that "did pose at times, but it was done naturally and without undue thought" (30). According to the narrator, "She just could not help it," which, throughout the novel, relegates Grace to being thoughtlessly fixated on chocolates and fashion to the chagrin of her friends and the awkward delight of male suitors (30). Similarly, the fetishized "French blood" frequently used to explain Mollie's supposed quick temper, "a temper which was not to be admired, and which Mollie tried so hard to conquer," becomes her defining quality (32). She is regularly caught in a sequence of emotive outbursts and subsequent apologies for her personality and heritage. Even male characters fall victim to this sort of ideological characterization. For example, Percy Falconer's affinity for "good clothes of a rather flashy type" and poor imitations of English mannerisms lead to ridicule from his peers (12). In an early appearance, he exclaims, "Charming weather we're having — my word!" and offers to buy the girls soda, but the implication is that his masculinity is second-rate, as the text increasingly solidifies societal gender expectations. Notably, Percy expresses unrequited affection for Betty throughout the novel, positioning them both in some ways on the outskirts of gender normativity as his great attention to beautifying himself contrasts her general disregard of that which is considered quintessentially feminine.

The overarching patriarchal themes and the implicit claims to American exceptionalism that identify the French as emotional and the English as queer are just two examples of the adult- 
sized statements that dominantly inform the development of adolescence in the novel. This dominance prevents a true double-voiced discourse or equal distribution of power between adult author and adolescent reader, both identified by Cadden as ethical necessities in YA literature. But in its story of explicit beginnings (e.g., of the Camping and Tramping Club) and personal discoveries (e.g., of Amy's surprise parentage), this proto-YA novel speaks to the formation of adolescence as a subject by the ideologies that dominate it, and, to borrow from Marxist philosopher Louis Althusser, the interpellation of the adolescent subject. In other words, adolescence, like all subjects, is realized or made real by ideology. Ideology establishes the gender norms, national identities, and economic principles, among other things, that supply the theoretical framework necessary to delineate what adolescence is, what it should be, and what it can be in the hands of those with power.

Narrators hold that power in proto-YA texts just as their adult counterparts do in life. An interesting textual example of such power is the narrator of The Outdoor Girls of Deepdale staking a claim over the main characters: "Our girls—I call them ours for it is with their fortunes that we shall be chiefly concerned — our girls lived near each other on the outskirts of the town" (36). In this example, by endorsing a shared ownership of these young women at the expense of their own adolescent voices, the narrator makes explicit something that is most often left implicit in literature (147). The young women, "our girls," although still voiced and continuously presented as contributors to the text's potential double-voicedness, are simply not their own. In this sense, they fail to be autonomous because of the inescapable presence and control of an adult narrator. Thus, any illusion of authoritative equality in the novel will always fall short.

All of the adolescent voices of Deepdale remain subject to their adult authors, a "Syndicate" of adult ghostwriters and marketers. Throughout the novel, the ideologies of these 
adults are laid out via dialogue and narration in accordance to a "power and repression dynamic," which, according to Roberta Seelinger Trites, "socializes adolescents into their cultural positions" (Disturbing 54). That is to say, the authority of adults constructs adolescence. Noticeable here is the theoretical interplay between the socialized, culturally constructed adolescent subject and the Althusserian subject interpellated by ideology. The two are effectively one and the same. Social influences, such as family and friends, and ideological factors, such as prevalent and widespread sexism, are recognizably interwoven in what Trites identifies as "the ways literary texts model adolescents internalizing their place within a culture's power structure" (54). The texts that young people read not only represent constructs of youth in their characters and storytelling, but they also have a powerful impact on how young people are positioned in the real world. So while Trites suggests that "both characterization and narrative structure are wedded to adolescent literature's function of communicating to adolescents about cultural power and repression," this same cultural power and repression delineates the parameters of fictional adolescent characters, just as it establishes what the adolescent subject is in a material sense (55). Importantly, The Outdoor Girls—Betty, Mollie, Grace, and Amy—in their first published appearance and throughout the whole of the series, are never quite characterized beyond the superficial. Perhaps this was a byproduct of the speedy but efficient process Stratemeyer employed, which is considered by many his greatest contribution to publishing, children's and otherwise. According to Watson, "[Stratemeyer] began fashioning story ideas into detailed threepage outlines. He sent these sketches to aspiring authors whom he had lured through the classifieds. Within a month, each hired pen would flesh an outline into a full novel” (57). It should be no surprise then that the four Outdoor Girls, imagined in just three pages, penned into existence by a slew of disparate voices, and rendered whole within a month, are very much not 
presented as real girls, even in a generous sense. When the narrator refers to Grace as a "regular Gibson girl," for example, the fashionable all-American girl archetype of the late-nineteenth and early-twentieth centuries isn't just invoked but wholly embodied by the character. Similarly, as Mollie is referred to as "Billie-boy" or simply "Billy" largely because of her last name, Billette, both the narrator and the characters of the novel make commentary on her temper and her supposed lapses of femininity. Mollie is cast as a "tomboy," a complex, gender-bending archetype that, according to Michelle Abate, was having its literary heyday in the late-nineteenth and early-twentieth century (Tomboys xv). While the four loosely outlined caricatures of young girls combine into a more detailed representation of adolescent girlhood, a number of possible motivations exist for not wanting each girl to be too individualized and for the narrative and series, as a whole, to rely on what Maria Nikolajeva identifies as "collective characters" (Rhetoric 67). In this framework, protagonists with the same role or function are observed as constitutive parts of a whole, and as Nikolajeva suggests, this technique is "one of the specific narrative features of children's fiction"; it is virtually nonexistent in fiction marketed toward adults (87). "The two main purposes of using collective protagonists," according to Nikolajeva, "are both didactic" (87). The first is that collective protagonists offer moderately varied subject positions to a wider range of readers, which Nikolajeva recognizes as originating with the tendency for readalongs to encourage children to empathize with characters. Second, this device "presents character traits more palpably, clearly divided between separate figures in the plot" (87). This interpretation accounts for how the four Deepdale girls function together pedagogically: first, as a storytelling contrivance that appeals to a broader selection of readers and, then, as a collective representation of a singular, more easily digestible subject. Yet, the ideological implications of all of this, where variance in prettiness, demureness, athleticism, and 
hair color make up the bedrock of the collective, bring to light the politically repressive nature of subjectivity, especially female subjectivity.

In her reading of Louisa May Alcott's Little Women, Nikolajeva deploys the concept of the "collective character" to complicate Jo's role as sole protagonist (73). She writes, "Viewing the four characters [Meg, Jo, Beth, and Amy] as one single protagonist, we see how the 'wellbehaved,' ladylike part of it chastises and tames the wild and independent part of her nature-a process that many a young woman in the nineteenth century had to go through" (75). As Nikolajeva notes, the subjugation of the wild and untamed, the manufacture of palpable subjects, and the manipulation of character by dominant ideology isn't restricted to literature. Likewise, it surely isn't restricted to the nineteenth century. Nikolajeva identifies in Alcott's work a conflagration of feminine components and societal discourses, where the narrative sets its disparate female caricatures in a sort of controlled burn in which only the ideal, most ladylike parts can survive. This phenomenon is similarly pronounced in The Outdoor Girls of Deepdale as well as throughout the Stratemeyer Syndicate's tremendously popular series fiction throughout the first half of the twentieth century. And as the twentieth gave way to the twentyfirst century, not only does the collective character persist as a didactic trope, the construction of American adolescent subjects, boy and girl alike, has followed a fairly consistent, often disheartening trajectory.

In 2006, when the queen bee of a group of fictional teenage girls - with varied prettiness, demureness, athleticism, and hair color—mysteriously goes missing from a small American town, the remaining four girls illustrate a collective character in ways both familiar and unfamiliar, and the resulting series supports an increasingly nuanced analysis of adolescent subjectivization (and, in turn, objectivization) in contemporary contexts. Just as the Outdoor 
Girls establish for this project one bookend in the early 1900s, the Pretty Little Liars provide the corresponding result following a century of subjectivization of American adolescence.

Stratemeyer and his contemporaries serialized and then mass-produced a distinctive form of sellable juvenile objects, like the twenty-three originally published Outdoor Girls books, not just for consumption, but also toward the end of producing young, American subjects. As discussed, the collective of Betty, Mollie, Grace, and Amy is subjectivized by the ideological commitments of their adult creators and omnipresent narrator, but as a collective, or a unified pedagogical object formed by adults' desire to cultivate only the best version of adolescence, adolescent desires are effectively suppressed. The creator of the Pretty Little Liars series, Sara Shepard, similarly adopts the form of serialized fiction for her collective of young, female characters. But, over the course of the century, the distinction between subjects and objects becomes increasingly and necessarily muddled as adolescent desire — that of readers and characters alike—-takes center stage.

\section{Desiring Subjects}

Set in the affluent suburb of Rosewood, Pennsylvania, a fictional town of material excess and upper crust clichés - like luxury cars and designer clothes, dysmorphic body ideals and racial homogeneity — the narrative, themes, and characterizations of the Pretty Little Liars series are, in easily discernible ways, all imagined as fantasies. Present are the fantasies of perfect hair and irreproachable popularity and lavish high school dances with true loves in tow. These imaginary fantasies are all rooted in ideologies that, again in the Althusserian sense, interpellate or transform the characters of the series as well as the adolescent audience into subjects. And in more ways than one, the subject of the Pretty Little Liars fantasy, just as in Deepdale, is young womanhood. Still, both as a popular series of young-adult novels beginning in 2006 and its 2010 
television adaptation, the Pretty Little Liars franchise and its fantasy is predicated on the desire of these young women.

A consideration of Lacanian desire provides an operative framework for examining the subject of young women presented in this series because it is precisely fantasy that "realizes the subject's desire" (Žižek 6). In other words, the fantasy world of the series lays out what is necessary to make desire real for the characters as well as the readers of each book and viewers of each episode. But just as the series consistently finds it necessary to illustrate the young feminine subject with relation to a procession of fathers, brothers, suitors, crushes, lovers, exlovers, (male) instructors, (male) classmates, policemen, and various scandalous combinations of each, male desire and its ideological implications cannot be omitted from our attention. It's through this fuller consideration that the complexities of the young feminine subject can be untangled. Pretty Little Liars is a story of stalking, of anonymous surveillance and of the torture of young women. An investigation of desire in this space, a prosumer-driven, multimedia fantasy world, must also consider who else, other than young women, is watching intently, gazing; what other fantasies or desires are at play and how this gaze affects the subject.

The notion of a prosumer, according to Women's Studies scholar Leisha Jones, “is proliferating and evolving beyond its jargoned origins" as simply a contraction of either producer or professional and consumer (441). The term holds significance in areas as divergent as economics, marketing, and mental health, but, for the purposes of the current examination of the subject, prosumers are proactive readers and viewers, engaged consumers who exist in contrast to their more passive counterparts.

In outlining the contemporary "prosumer girl" of the Twilight Saga fandom, Jones describes the phenomenon as such: 
$[\ldots]$ the prosumer experiences no disconnect between use value and sign value; sign value is use value. Where the consumer's identity is accretive, trafficking in signs as a means to reify one or several identities, the prosumer ingests signs and also emits them as a single gesture. The identity of the prosumer is a sign engine, continually replenished and dispersed, locatable only through significatory patterns found on the Web and elsewhere. (450)

Essentially, for prosumers of Pretty Little Liars, media objects—such as the novels, the television series, or tweets discussing either-have indistinguishable value in usefulness and signification. Consumers, for example, measure the use value of a car by its ability to drive safely from point A to B, while its sign value can range dramatically from jalopy to Jaguar. Prosumers, on the other hand, operate as if the Jaguar can easily be a jalopy and, not only vice versa, but the makeshift car they've put together themselves in their garages can be valuable all the same. Prosumers are individuals who eschew the distinction between the function and significance of media objects. Fans of Pretty Little Liars may have divergent opinions on the 160 television episodes, sixteen core novels, myriad of ships, fan sites and theories, but their unique, multimedia engagement is what imbues each of those objects with value and, effectively, meaning. This interpretation is invaluable to this chapter's considerations of Pretty Little Liars, its narrative, its audience, and the contemporary evolution of adolescent subjects from their more analog antecedents.

Likewise, this interpretation allows the various media and modes of the series to be treated as a unified corpus, despite narrative and presentation differences, because the signs are actively maintained by the prosumer even as signifiers are altered. For example, the sixteen core novels follow the main characters from eighth grade through the summer after senior year, while 
adult women in their mid-to-late twenties depict high school juniors and seniors for seven seasons on the television series. The characters and other elements of the series vary in ways both subtle and substantial for reasons both commercial and aesthetic. Yet, they exist most meaningfully as signs within an order of imaginary objects, rather than as simply functions of their names. In this sense, each Liar is established to signify pretty, rather than call to mind a specific character or object. For a prosumer of both the novels and television adaptation, Emily Fields, for example, signifies both the strawberry blonde youngest-of-four described in the books and the dark haired, olive skinned only-child of the television series. The two Emilies share her swimming, her queerness, and the location of her home in the two Rosewoods. However, the sign of Emily is more than shared similarities but consists of what else she may signify within a prosumer's own system of signification: loyalty, bravery, embarrassment, non-traditional romance, diversity, exclusion, representation. Again, the unique qualities of the prosumer of Pretty Little Liars allow for an interpretation of its signs as "trans-media," that is, the signs operate similarly across its varying modes and delivery technologies. These signs are markedly comparable to the smartphone-wielding, social media-savvy young subjects of the series themselves.

Likewise, it is also this interpretation that allows the audience to be treated as subjects operating under the same systems of signification as the Pretty Little Liars. Readers of the novels, watchers of the series, followers of the tweets, commenters on the blogs, writers of the fan fic, cosplayers of the characters, buyers of the Citizens of Humanity (a Los Angeles-based premium denim brand) jeans the characters wear actively operate within a system of objects whose signification is sustained by fans, creators, and characters with their respective boundaries blurred. 
But in examining the subject-ness of young women, we must also acknowledge the unrelenting object-ness that coincides with it. That is, the ways young women look out onto the world, the ways they consume and produce value alike, and their desire are interwoven with ways the world looks onto them, the ways these young women are consumed and their value repurposed, and their desirability. Where some may see repressive force in objectification, the subject is tied inseparably to its existence as an object. In fact, Pretty Little Liars, in particular, establishes, with the shininess of its fantasy and the palpable sign value of its luxury and opulence, a system of signification where objectification is made to seem even attractive. To become popular and pretty subjects, the four main Liars-Spencer Hastings, Aria Montgomery, Hannah Marin, and Emily Fields - voluntarily undergo an objectification at the hands of their most popular and pretty friend, Alison DiLaurentis, which they regularly acknowledge within the narrative. "Sometimes in Ali's presence," the very first novel of the series reads, "they didn't feel real, exactly. They felt kind of like dolls, with Ali arranging their every move" (32). Even after Alison's sudden disappearance, the doll imagery pointedly recurs throughout the book series and television show.

Despite being penned by a female author, the series suggests that being an object, a doll, especially a pretty and little one, is at least commensurate with being a subject in a contemporary, westernized system of value and signification wherein inanimate objects can regularly be seen as being treated more favorably than real live bodies. These objects, young women and their bodies, are of special interest to Jean Baudrillard, when he responds in The Consumer Society: Myths and Structures to the question, "Is the Body Feminine?":

We may say both of women and the body — as we may say of young people and all the categories whose emancipation constitutes the leitmotiv of modern democratic society- 
that all the things in whose name they are "emancipated" (sexual freedom, eroticism, play, etc.) form themselves into systems of "tutelary" values, "irresponsible" values, simultaneously orientating consumer behaviour and behaviours of social relegation, $[\ldots]$

Women, young people and the body $[\ldots]$ are integrated and recuperated as a "myth of emancipation." Women are given Woman to consume, the young are given the Young and, in this formal and narcissistic emancipation, their real liberation is successfully averted. (138)

For Baudrillard, the possibility of emancipation from a repressive social economy is a myth. But it is also impossible, for women, young people, and every body, to be emancipated from being objects of that economy of valuation and signification. The leitmotiv is that we are all given our own signs, just as a young, impressionable reader will be given a "young adult" novel filled to the brim with young, impressive objects, to consume and imagine some sort of liberation from adolescence or their own coming of age. In the pages or episodes of Pretty Little Liars, characters and audiences alike can fantasize about being either an empowered subject revolting against an objectifying patriarchy or a beautiful object pursuing and ascribing her own feminine values. The myth is that they can be either rather than an amalgam of both. Thus, to effectively pursue an understanding of what being a subject means, this consideration of duality must always remain, for better or worse.

In addition, to gaze presupposes a split between a subject and an object, a gazer and a gazed upon. For Jacques Lacan, this split is essential to the mechanisms behind identification and desire. For example, in the first novel, when Emily Fields first meets Maya St. Germain, the girl who moves in next door into the former home of her now-missing friend and secret love interest, Alison, Emily's sequence of gazes demonstrates these mechanisms well. She first sees the piles 
of Alison's belongings out on the curb, pulling out a swimming medal she'd left at Alison's years ago when they'd been playing "Olympian Sex Goddesses," a private game they'd made up (49). Whether Emily re-identifies as a "Sex Goddess" is left for interpretation, but notably she recognizes herself within a private relationship that is no longer viable and as the girl who isn't missing but has some part of her missing. The scene heavily implies her past and present desires. When Emily refocuses her gaze onto Maya, one of the first things Emily notices is this: "The girl wore a yellow tank top whose strap had slid off her shoulder to reveal an orange and green bra strap. Emily wasn't certain, but she thought she had the same bra at home. It was from Victoria's Secret and had little oranges, peaches, and limes all over the, er, boob parts" (49).

Emily's identification of the bra and assertion of herself as a Victoria's Secret-shopping, "boob-parts"-having subject represents her gaze, which, in turn, objectifies Maya. Maya persists as an object as she progresses from lover (sex object) to suspect (object of the mystery) to murder victim (object of horror) within the divergent narratives of the novels and the television series. Eventually, Maya is killed in the television series and the killer is revealed to have been an obsessed stalker, Lyndon James, who had been angry that Maya hadn't seen (or gazed upon) him as a lover ("The Lady Killer" S03E12). Essentially, Maya is brought into this narrative world as an object through the gaze of Emily. She develops into a romantic subject and a subject in her own right as she gazes back affectionately at Emily, even becoming a "series regular" in the second season of the television series, effectively the medium's most palpable way of legitimizing a subject. She then dies as a subject-object when Lyndon's desire to consume her wholly as an object challenges the legitimacy of her gaze. He expresses at multiple points his frustration with Maya leading him on, not seeing him as the love interest he truly is, and implies even that Maya's queerness was a part of this act ("Single Fright Female" S03E13). In Maya we 
witness a violently irreconcilable tension between being a young female subject and young female object, which is a realization of the Lacanian split.

But in this Lacanian interpretation, it's important to note that we never see a "true" Maya, even as we gaze upon her. As a character, she's rarely presented with as much detail as the main Liars. Maya is a Black lesbian of unknown Californian origin, after all. She remains enigmatic and obfuscated in such a way as to simultaneously objectify her in "otherness" while periodically serving as a possible threat to the safety of the Liars and the town. She is, after all, a Black lesbian. In essence, the Lacanian gaze targets an object, but despite the aim, what is actually seen is "puzzled by our desires and anxieties" (Zizek 11). In this sense, the objects targeted by the gaze of those within and outside of Rosewood are as distorted and blurred as the self-image that triggers Hanna Marin's bulimia; the misrecognition of affection that causes Lyndon to murder Maya; or even the shadowy figure of A, the mysteriously omnipresent perpetrator(s) of various acts of bullying, torture, and violence throughout the series.

That desire is not the object of the gaze may be unclear, but this is a point that cannot be overlooked. Maya for Emily, a skinny body for Hanna, and all four Liars for A are simply the object-causes of desire. In Lacanian terms, each function as an objet petit a(utre) - the little ("petit") other ("autre"). The existence of the objet petit a causes desire to become imagined, to come into being in image.

Remarkably, the imaginary world of Pretty Little Liars is structured in such a way that it is teeming with shiny objects - from the material wealth of its setting to the romances, intrigue, dangers, and adventures the girls embark upon — and thus purposefully erected object-causes of a prosumer's desire. Still, a primary antagonist named "A" operates largely as a metonym for Alison DiLaurentis and the series' inquiry into prettiness, littleness (or youth), and lies. "A" 
doesn't need to be a direct reference to Lacan's objet petit a, but any desire for that to be so is apropos of the way in which an object may elicit a desire and from that desire a corresponding subject can potentially manifest.

In this process of manifestation, Lacan's framework is noticeably formative but neither chronological nor traditionally causal. That is to say, although the objet petit $a$, desire, the gaze, and the subject-object split are all ultimately linked and essential to one another, Lacan does not describe a sequence of events, one element causing another, but rather concurrent, nearly indistinguishable phenomena. All at once, when A first gazes at Aria, sending her the first of many haunting text messages, $\mathrm{A}$ is realized as a subject; A's desire is realized in the imaginary (i.e., the realm of images), and Aria comes to the unpleasant realization that not only did someone else see her get intimate with her AP English teacher, but that she also exists as an object to be seen. The fear and anxiety that comes from this, again, represents perfectly the split between subject and object, and is embedded into the foundation of the story of these girls. Moreover, the narrative of Pretty Little Liars relies heavily on "televisual fear," a fear that we are "perfectly, completely visible to a gaze that observes us from afar" (Copjec 15). The series is a true mystery-thriller in this way and uses the awareness of the gaze in ways both overt and subtle to establish a palpably imaginary (image-based) world. Aside from an emphasis on the "pretty," the novel series is wholly written from the alternating perspectives of the four main Liars, allowing readers to see only what they can see, moving from scene to scene as if the reader were a camera following each girl, with narrative suspense building with image after image. Moreover, as Pretty Little Liars is represented on television and several screens feature so prominently in the fantasy world itself (e.g., cell phones, computers, and in-story televisions emblazoned with the face of the missing Alison Dilaurentis), borrowing from film theory in this 
examination of the gaze seems warranted. Likewise, the marriage of film theory and Lacanian psychoanalysis allows us to effectively discuss the significance of those screens for the subjects involved-especially the women.

Film theorist and philosopher Joan Copjec, in clarifying misconceptions of Lacan's contributions to film theory, offers a valuable interpretation: despite often being held as "one of the clearest and most succinct descriptions of" the interrelation between the gaze and the apparatus (i.e., that which sets an image before a subject), the screen is not a mirror (16). Copjec continues to explain that often this misconception has allowed film theorists to oversimplify and misidentify subjectivization, feminine subjectivization in particular, under the gaze of patriarchy. "The panoptic gaze," she writes, "defines, then, the perfect, that is, the total visibility of the woman under patriarchy, of any subject under any social order, that is to say, of any subject at all. For the very condition and substance of the subject's subjectivity is his or her subjectivation by the law of the society that produces that subject" (17). Here Copjec elaborates beyond traditional feminist views of the Panopticon as the proverbial prison where the male gaze is everpresent and subjugates the woman. She argues instead for an interpretation truer to Lacanian psychoanalysis. The gaze, in this interpretation, provides subject-ness to the woman, and in that, visibility not only to others but also to herself. Knowledge of herself and, for Copjec, all knowledge, is otherwise impossible without the gaze. It is precisely because "the panoptic gaze defines perfectly the situation of the woman under patriarchy" that the "perfection of vision and knowledge" can exist. Notably, "perfect" in this sense does not refer to any particular ideal, not 20/20 vision or omniscience, but rather a completeness or fulfillment.

Along these lines, it would be an understatement to claim that the Pretty Little Liars become more visible and more knowledgeable under the gaze. While being stalked and 
surveilled throughout much of their formative years within a similarly panoptic arrangement erected by A, every secret and lie the girls hold dear, even from one another, is continually made visible through text message, tabloid news exposés, and instant message chat screens: Aria's love affair with her teacher and her father's infidelity; Emily's sexuality, both as queer and active; Hanna's eating disorder and her shoplifting; Spencer's by-any-means-necessary approach to academics and romance. All of these issues become visible knowledge, that is, knowledge yielded through the aforementioned perfect or complete exposure of these young women. Additionally, knowledge of their imaginary world becomes increasingly visible as well. Fairly early in the series, when news breaks of her disappearance and apparent murder, Alison's face appears on every television set in Rosewood for all to gaze upon. This subsequently exposes many men, often older men, as having had visibly inappropriate interests in her. Popular upperclassmen are exposed as perverse. Police officers are exposed as corrupt. Later, when the main Liars are televised for their apparent involvement in the case surrounding Alison's disappearance, they are publicly labeled the "Pretty Little Liars" by the media. Within the narrative, the awareness of the gaze, while making the Liars noticeably uncomfortable, brings an awareness of the self as a subject. This subject is interpellated by gender ideologies that ascribes prettiness and littleness as essential features of young girls, whether they're liars or not. Likewise, this subject is unavoidably visible as an object, like all subjects are, but the perfection of the young woman subject, the perfection of her vision and knowledge, according to Copjec, is gained only "at the expense of invisibility and nonknowledge" (17). To clarify, young women can never exist without the vision and knowledge of self that derives essentially from being seen. A woman, like any subject, can neither be invisible nor can there be nonknowledge of her. Both 
are impossible. This understanding ties her subject-ness inseparably to her object-ness, to her visibility by the gaze.

For all the talk of how the gaze realizes subjects and objects and the unnerving split between them, matters are further complicated by the fact that the subject will never see itself within the Lacanian gaze. It's too tempting but ultimately insufficient for some readers of Lacan to make such a claim. Prosumers of Pretty Little Liars cannot see themselves as subjects as they gaze upon the representative objects of the series. To the contrary, the subject "cannot be located or locate itself at the point of the gaze, since this point marks, on the contrary, its very annihilation" (Copjec 35). What prosumer subjects of Pretty Little Liars see is precisely what the Liars themselves see when they gaze back to A time and time again: essentially nothing. And it's scary. The gaze for the subject is founded not on what is seen, but what is un-seeable. Screens, in this sense, represent for us all of the images we gaze upon. For Lacan, there's nothing behind the screen. It's only significant that there seems to be something. There exists an impossible reality, especially in the realm of serialized adolescent subjects.

When one A is unmasked, as they are time and time again to varied reactions of shock and horror, the subsequent rebirth of a new, equally terrifying yet enticing A reveals what is both always missing and always present: an impossible reality. Young women subjects have to deal with the impossible reality that claims simultaneously that every man is a suspect in your murder and torment but you still need one for the prom. An impossible reality that claims looking like twenty-five years old is the ideal for thirteen-year-olds. An impossible reality that claims affluence is a norm for young women but violence and abuse towards them is mysterious.

At its core, Pretty Little Liars is predicated on desire; that is to say, on a trajectory toward what is inaccessible and missing. And for much of the series, its aim is ostensibly toward Alison 
Dilaurentis, a shiny, young object of desire for the remaining residents of Rosewood and a thoroughly complicated subject gone AWOL. She remains inaccessible and missing for much of the television series and arguably throughout the entire book series due to a string of misrecognitions; impersonation hijinks both virtual and twin-based are afoot in Rosewood. But through images, flashbacks, and memories of her, she becomes an imaginary representative of all the fantasies of the Rosewood subject. Alison represents fantasies of popularity and power. She is a stand in for blonde-haired, blue-eyed fantasies of white beauty as well as sexual viability. She is imagined as the ultimate friend and the ultimate enemy. The desire of the contemporary young woman springs forth from this fantasy. But so too does male desire, embedded in the panoptic prison that Rosewood (and the world) eventually reveals itself to be. Nonetheless, the world gazes upon the missing Alison just as subjects gaze upon the world and see images in a screen, blurred and distorted by desire. So while this chapter offers the Outdoor Girls as representative of the lopsided ideological construction of adolescent subjects based solely on what adults desire adolescents to be, the Pretty Little Liars series suggests that adolescent subjects, desiring in their own right, aren't simply passive in their subjectivization but, in fact, are key to uncovering the complexities of subjecthood, the inexorability of subject-object duality, and the potential for all subjects to be more.

\section{Mystery Subjects}

In her book Girl Sleuth: Nancy Drew and the Women Who Created Her, Melanie Rehak explores the early-twentieth century inception of Nancy Drew as well as Stratemeyer's operative framework for producing adolescent literature. Rehak's research includes the following memo from Edward Stratemeyer himself to the original publisher of the Nancy Drew Mystery Stories series, Grosset \& Dunlap, dated September 1929: 
These suggestions are for a new series for girls verging on novels. 224 pages, to retail at fifty cents. I have called this line the "Stella Strong Stories," but they might also be called "Diana Drew Stories," "Diana Dare Stories," "Nan Nelson Stories," "Nan Drew Stories" or "Helen Hale Stories" . . .

Stella Strong, a girl of sixteen, is the daughter of a District Attorney of many years standing. He is a widower and often talks over his affairs with Stella and the girl was present during many interviews her father had with noted detectives and at the solving of many intricate mysteries. Then, quite unexpectedly, Stella plunged into some mysteries of her own and found herself wound up in a series of exciting situations. An up-to-date American girl at her best, bright, clever, resourceful and full of energy. (1)

What this note offers a contemporary critical reader is not a brief sketch of "Stella Strong," who would become Nancy Drew after the insistence of those with a better ear for names, as an "up-todate American girl at her best," but the unshakable construction of what would become an "American girl at her best" thenceforth. What Stratemeyer aimed to do with the Nancy Drew Mystery Stories, notably with logistical details of cost at the forefront, and what he had already done with the Outdoor Girls series as well as so many others, was to use adult authority to impress on young readers a very specific ideology, without which, as Althusser says in a different context, no subject at all could exist.

But what of a subject's desire? "In her 1930 debut," according to Watson, "[sixteen-yearold] Nancy Drew drives a convertible, pilots a speedboat, fixes a sprained ankle, repairs a motor, quotes Archimedes, and finds a missing will in an old clock. Such expertise quickly made the adventure series of this superteen the best-selling Stratemeyer work of all time" (58). For nearly 
a century, fans have continually prosume-d the girl detective and gazed intently upon her impossible adventures. Even Nancy's affinity for solving mysteries on her own is described by Stratemeyer in 1929 as "quite unexpected." Pointedly constructed as an object to be consumed by "girls verging on novels," Nancy has become a powerfully influential literary figure embodying ideologies of adolescence and femininity. In this, Nancy Drew, her Outdoor Girl predecessors, and their progeny in the Pretty Little Liars franchise are all realized as subjects to be adored and even emulated by their adolescent audiences. Likewise, as subjects, their desires tend to present themselves in puzzling ways, whether in a secret clock, a hidden staircase, Deepdale or Rosewood, PA, or wherever else the split between objecthood and subjecthood begets impossible realities. These realities, entertainingly unbelievable but importantly and convincingly adolescent, are impossible due to the undeniable power imbalance between adult and adolescent voices; between dominant ideology and those dominated by it; and between the desires of adult authors and those of young readers. As a result, adolescence necessitates aiming toward the impossible (e.g., being the prettiest, the smartest, the most popular) but missing. In the context of adolescent literature, Trites prefers to consider this impossibility as "paradoxical" (83). She writes:

[...] adolescent literature seems to delegitimize adolescents, insisting that "adolescentness," especially immaturity, is unacceptable, even though the surface intention of most YA novels is ostensibly to legitimize adolescence. Texts accomplish this delegitimization by conveying frequently to readers the ideological message that they need to grow up, to give up the subject position culturally marked "adolescent." (83) In this interpretation, young people, after being subjectivized, remain positioned at the outskirts of adult culture and under a special sort of scrutiny. They remain subject to our adult ideologies. 
They're objects that paradoxically shouldn't be. They're expected to just grow up. But in considering these adolescent subjects as desiring in their own right and examining the power inherent to the gaze (adults toward the young, the young back, etc.), there exists an alternative interpretation that, if not resolving this paradox, at least reconfigures it productively as a mystery worthy of investigating further.

In 1899, when Edward Stratemeyer sought to build a publishing empire fueled by imaginary young people at a point when nearly half of the American population was under twenty, he may be considered to have legitimized American adolescence in some important cultural and economic sense. The very concept of a "teenager" would emerge soon thereafter. Additionally, the Outdoor Girls, with their collective character and plainspoken narrator working in conjunction to construct a restrictive feminine ideal, may very well delegitimize some real life young readers who don't fit neatly into this mold. Of course, this is the paradox of adolescent literature that Trites recognizes (Disturbing 83). Adolescent subjects may hope to be validated by the media, respected by adults, legitimized in their adolescence, but this legitimization is always an impossibility. Pretty Little Liars exhibits this well in the shadowy figure of A, who remains omnipresent in the lives of the series' young protagonists but persistently undermines their subjecthood with stalking, taunting, and harassment.

The mysterious A, depicted as impossibly capable and unmistakably resentful, is explicitly a product of the gaze towards Alison, the resident objet petit a. In describing the Lacanian gaze, Copjec applicably writes, "The gaze is not clear or penetrating, not filled with knowledge or recognition; it is clouded over and turned back on itself, absorbed in its own enjoyment. The horrible truth, revealed to Lacan by Petit-Jean, is that the gaze does not see you. [...] it will not validate you" (36). As A gazes upon these young women in their most private 
moments, revealing intimate knowledges, forcing upon them the terrible split between subject and object, the young women can never be truly seen by the gaze. Aria, Hanna, Spencer, and Emily will never be validated by A just as Betty, Mollie, Grace, and Amy will never be ideal girls regardless of the moments when this is precisely what respective members of each group demand. In this, neither adults nor the media they create can ever legitimize an adolescent subject; rather all we can hope to do is see some image of them, gain some knowledge of/from them. Often in children's and adolescent literature, under the ominous, sometimes harmful, but always necessitated weight of the gaze, the young subject emerges from the impossible reality of being invisible and unknown to being visible and known. But as fully realized subjects able to be seen but—perhaps more important—able to see themselves, young people can then gaze back, setting aim with their desire. "The horrible truth" is still the same. What lies beyond the screens, narrative structures, and collective characters if they're ever unlucky enough to see it, beneath A's hood, lurking in the woods as they camp and tramp, at the center of the mysterious theatrics that typify series fiction, and within us all is nothing, and it's frightening. Just as the threat of the gaze is founded not on what is seen, but what is unseeable, children's and adolescent literature, in this sense, has come to represent many of the images we can't gaze upon directly. Readers see only a lacking in the image of the ideal girl being, in fact, a collective of four dissimilar Outdoor Girls of Deepdale. Audiences are shown only absence in the image of Alison DiLaurentis, the girl all the boys want and all the other girls want to be. Nonetheless, in children's and adolescent literature, this lacking, this absence, this nothingness represents the potential of anything and everything, which is unmistakably powerful. 
On some basic level the subjects of children's and adolescent literature are children and adolescents, but the phenomena and discourse surrounding subjectivization are often more complex. In Looking Glasses and Neverlands (2004), Karen S. Coats describes how subjectivity manifests within systems of representation, like a baby recognizing herself in a mirror image, but, nonetheless, "it is still the Other's system, something external to him that he has taken on" (Looking Glasses 3). In this, Coats recognizes some of the inherent complexities of subjecthood, that even the word "has resonances of both agency and subservience," as well as conflicting grammatical, academic, and legal connotations, to say the least, and Coats advises "to hold these contradictions in unresolved ambiguity" (3). Thus, it's no surprise that mysteries in some form abound in children's and adolescent literature long after Nancy Drew, as protagonists—whether collectively or as individual representations of youth—uncover clues and unearth plots just as readily as they discover themselves proverbially coming of age. The unresolved ambiguity inherent to subjectivity isn't unique to young subjects; we nevertheless often find narratives most equipped to working and reworking these subjects within children's and adolescent literature. The following chapter proposes that the critical frameworks traditionally deployed to read these works - those that center adult subjects and dominant ideologies yet take adolescent desire, in all its paradoxical impossibilities, for granted — are ill equipped to help us recognize the radical power of the young, the childish, the small, the repressed, the minor. 


\section{CHAPTER II: ON POWER, MINORS, AND MINOR LIT}

Mr. Covey succeeded in breaking me. I was broken in body, soul, and spirit. My natural elasticity was crushed, my intellect languished, the disposition to read departed, the cheerful spark that lingered about my eye died; the dark night of slavery closed in upon me; and behold a man transformed into a brute!

-- Frederick Douglass, Narrative of the Life of Frederick Douglass, an American

Slave

One morning, as Gregor Samsa was waking up from anxious dreams, he discovered that in bed he had been changed into a monstrous verminous bug.

-- Franz Kafka, The Metamorphosis

When considering the possibility of a distinctive theory of children's literature in her essay "Theory, Post-Theory, and Aetonormative Theory," Maria Nikolajeva proposes the concept of aetonormativity as an age-based analog to heteronormativity. She theorizes an "adult normativity that governs the way children's literature has been patterned from its emergence until the present day" (16). An aetonormative inquiry, for Nikolajeva, reveals the alterity, or otherness, of child and adolescent subjects. Likewise, as a critical lens, aetonormativity soundly represents the imbalance of power inherent to children's and adolescent literature, literatures that are, for the most part, "created by those in power for the powerless" (16). Despite the obvious and undeniable reality of both adult and child subject positions, priority is often given to adult normativity, adult ideology, and adult desires, reifying the oppressive function of all literatures, especially for - but certainly not limited to - children and adolescents. Perhaps this is why, when 
reflecting on the oppressive nature of slavery, his own experiences, particularly in 1834 when under the ownership of noted slave-breaker Edward Covey, Frederick Douglass, in the quotation above, prioritizes his manhood. In becoming a brute, Douglass notably claims to be diminished as a man without acknowledging himself as a boy of nearly sixteen years old, whose power has been violently suppressed by an adult that takes so much, including his literacy.

In the second quotation, Kafka begins his 1915 novella The Metamorphosis with another powerful image. The story follows a salesman-turned-bug and his family through the aftermath of this absurdist transformation and, as one of the major figures of twentieth-century literature, Kafka's writing has incited a number of interpretations and claims to meaning. What could it mean to wake up having been changed into a bug? How must we interpret the protagonists' interactions with the eerie and enigmatic bureaucracies of The Trial (1925) or The Castle (1926)? What sort of Oedipal drama or childhood trauma must Kafka have been working through in Letter to His Father (1919) or throughout his career? French philosophers Gilles Deleuze and Felix Guattari devote a book to recasting the works of Kafka and suggest that questions like these miss the mark, largely because they're informed by theoretical frameworks not specially attuned to Kafka's unique work. While Nikolajeva is able to draw attention to the domination of one audience by the literatures specifically intended for their consumption, Deleuze and Guattari challenge some of the underlying principles of dominant literary discourse. Together they offer productive models for theorizing the radical power of the supposedly powerless.

In the foreword to Kafka: Toward a Minor Literature, French literature scholar Réda Bensmaïa writes, "It quickly becomes obvious that Kafka has been misinterpreted and, from a certain point of view, "misunderstood," only because he has for a long time $[\ldots]$ been judged to be the embodiment of a concept of literature (and of the Law_of Genre, of Desire) that is totally 
inapplicable to his work" (xiv). Deleuze and Guattari take it upon themselves to suggest an alternate concept of literature - one that rejects interpretations of a text by way of its expressions, representations, or imitations into readymade forms of meaning, being, and nature. Instead, Deleuze and Guattari acknowledge that Kafka's status as a Prague Jew in the early-twentieth century, his usage of a German language heavily influenced by the politics of territory, his coming of age in cramped, cold spaces, and even his tumultuous relationship with his father are not merely significant nor influential to the forms of his literature, but are in fact intimately definitive of the literature. Freed from his interpreters - the theological and the psychoanalytical, in particular-Kafka, according to Deleuze and Guattari, can be most effectively viewed through the lens of "that which a minority constructs within a major language," or what is poignantly identified as minor literature (16).

"The three characteristics of a minor literature," write Deleuze and Guattari, "are the deterritorialization of language, the connection of the individual to a political immediacy, and the collective assemblage of enunciation" (18). With regard to the first characteristic, Deleuze and Guattari suggest a "high co-efficiency of deterritorialization" in all minor literature; that is to say, territory itself is challenged when the German language, for example, becomes the necessary language of communication and writing for Jews in Prague, who are simultaneously a part of this displaced German-speaking minority and excluded from it. The second characteristic speaks most directly to the inherent political nature of minor literature, especially in contrast to major literatures, which, according to Deleuze and Guattari, join "individual concerns (familial, marital, and so on) $[\ldots]$ with other no less individual concerns, the social milieu serving as mere environment or a background" (17). Likewise, the final characteristic suggests a collective value unique to minor literature because, instead of the individual mastery of forms common in the 
great major literatures, "what each [minority] author says individually already constitutes a common action, and what he or she says or does is necessarily political, even if others aren't in agreement" (17). Importantly, each of the three key qualities of minor literature, while comprehensively detailing the minority position, speak directly to what constitutes the majority—-power, especially in terms of language, politics, and valuation.

A primary goal here is to examine this power in the context of children's and adolescent literature. Just as Deleuze and Guattari invoke Kafka to confidently argue that "a minor literature is much more able to work over its material," this chapter contends that the material of children's and adolescent literature - its texts, its subjects, its discourses, etc.—is more effectively worked by adopting the theoretical framework of minor literature and exploring further what the minority position yields (19). While "minority" here, as for Deleuze and Guattari, means something simultaneously dissimilar and similar to the common, racialized usage in the West today, this reworking of minor literature is firmly situated in the context of "minors"- those considered lesser by virtue of aetonormative perceptions of age as well as the cultural and legal parameters of their identities. Moreover, this chapter aims to present "minor lit" as a refreshed framework, incorporating the colloquialism "lit" toward two ends: first, as an attempt to reclaim those texts often dismissed as not literary enough (e.g., "chick lit," "kiddie lit," "zit lit," "not real literature"). Second, here "lit" is an affirmation of contemporary discourses influenced most directly by what linguist Penelope Eckhert calls the "production of difference that defines adolescence linguistically," yet another example of language-based deterritorialization (368). As a much-needed challenge to the "major" and inherently adult-dominated discourses of children's and adolescent literature and culture, a minor lit is much better able to "work over" its unique and diverse material. 
To go about this work, this chapter is organized around, first, thoroughly defining minor lit by way of unpacking the work of Deleuze and Guattari and placing it in direct conversation with some of the more prominent theoretical discourses of children's literature with regard to power; second, speaking directly to the concept's applications in the critical scholarship of children's and adolescent literature; and last, examining closely texts that, like Kafka's, exemplify the key characteristics of a minor lit: The Narrative of the Life of Frederick Douglass (1845), Salinger's The Catcher in the Rye (1951), and Morrison's The Bluest Eye. Just as minor for Deleuze and Guattari "no longer designates specific literatures but the revolutionary conditions for every literature within the heart of what is called great (or established) literature," it must be made clear that the "minor" in a minor lit also functions not in a specific or exclusionary way, but as a marker of a potential revolution (18). A minor lit is revolutionary in that it challenges aetonormativity and what is considered the territory of minors. It speaks to the politics of the minority position, as it exists distinctly from that of its majority counterparts. And a minor lit speaks to the collective literary value of minor subjects, the many evocations of childhood and adolescence in literature as an assemblage of meaning that resists traditional interpretation. All of this is pertinent because a minor lit is necessarily complicated. And a minor lit is powerful despite major resistance to that power.

\section{On Territory and Power}

According to children's literature scholar Perry Nodelman, "the idea that children's literature might have —indeed, might characteristically and even inherently and unavoidably imply — an adult audience as well as a childlike one is a key feature of some important theories of children's literature" (207). For Nodelman, this dual audience quality of children's literature is evident in the practical and economic dimensions of the field, such as the production, marketing, 
and purchasing of its books; the professional critique and interpretation of its narratives; and, in many cases, the reading and performance of its words to pre- and peri-literate targets. Likewise, the dual audience of children's literature leads to discernible complexity, perhaps even an imbalance. Nodelman continues, "What texts of children's literature might be understood to sublimate or keep present but leave unsaid is a variety of forms of knowledge—sexual, cultural, historical — theoretically only available to and only understandable by adults" (206). It is here that I can most meaningfully delineate the territory of children's literature as an allocation of epistemologies and forms to children but markedly not of children due to what—or whoremains hidden within. This "hidden adult," as Nodelman coins it, lurks in these ostensibly childfriendly texts like "a shadow, an unconscious," providing the audience with "a more complex and more complete understanding of the world and people that remains unspoken beyond the simple surface but provides that simple surface with its comprehensibility" (206). That is to say, the epistemic territory of children's literature-its relationship to knowledge both global and social — may be sufficiently complex, but it nonetheless remains only superficially, if at all, the territory of its children and adolescent readers.

Others within children's and adolescent literary scholarship have drawn some attention to this territorial dispute. Mike Cadden, for one, questions whether the narrative address itself utilized in adolescent literature leaves any room for adolescence, writing, "Novels constructed by adults to simulate an authentic adolescent's voice are inherently ironic because the so-called adolescent voice is never — can never be — truly authentic" ("Irony" 146). Similarly, Roberta Seelinger Trites suggests "adolescent literature seems to delegitimize adolescents" (Disturbing 83). Whether it's hidden or sublimated, ironic or paradoxical, the deterritorialization of child and adolescent readers from the body of literature that bears their name(s) is an aetonormative 
exercise in the negotiation of power. Moreover, there exists even some tradition of associating the young with other politically vulnerable populations due to their shared positions of marginalization. Although the article is now dated, Nodelman illustrates this when he contrasts the rhetoric of childhood and the colonialist language surrounding Orientalism to reveal "a number of interesting things" before ultimately settling on "a benevolently helpful colonizing attitude towards children" ("The Other" 29, 34). In this, deterritorialization is always a phenomenon of power. Investigating what that deterritorialization means, on the other hand, reveals how interpreting children's and adolescent texts as a minor lit can be beneficial to critical efforts to understand power and its machinations.

In Anti-Oedipus: Capitalism and Schizophrenia, Deleuze and Guattari’s greatly influential first collaboration, they write (with their distinctive flair for the abstruse): The social machine or socius may be the body of the Earth, the body of the Despot, the body of Money. It is never a projection, however, of the body without organs. On the contrary: the body without organs is the ultimate residuum of a deterritorialized socius. The prime function incumbent upon the socius, has always been to codify the flows of desire, to inscribe them, to record them, to see to it that no flow exists that is not properly dammed up, channeled, regulated. When the primitive territorial machine proved inadequate to the task, the despotic machine set up a kind of overcoding system. But the capitalist machine, insofar as it was built on the ruins of a despotic State more or less far removed in time, finds itself in a totally new situation: it is faced with the task of decoding and deterritorializing the flows. (33)

In this, one of their early usages of the term "deterritorialization," the pair offers a brief history of society's relationship to territory in the face of political and economic shifts. It must be first 
understood that, for Deleuze and Guattari, we're all machines. In fact, everything is a machine. "The breast is a machine, it produces milk," they write, "and the mouth $i[s$ a] machine coupled to it" (1). The social machine or "socius," in this sense, is plainly the machinations of a social body (e.g., of people sharing this planet, under a monarch, engaged in commerce, etc.). As a machine or body, its parts or organs constitute its territory of existence just as a machine or body can regulate its parts or organs as territory inasmuch as it desires. But what the two eventually posit about capitalism, or "the capitalistic machine" built atop political or "despotic" scaffolding, is the way in which power, particularly that of money, leads to territory loss and new meaning. Of course this model is not chronological but rather speaks to psychic structures at play all at once. That is to say, children may be a part of the machine of children's and adolescent literature, but just as capitalism or adults appear to be a major factor in its meaning making, actual children and adolescents may have always already been deterritorialized from being parts of the machine at all. Minor lit, I propose then, is simply the acknowledgment of this body without its organs, a literature machine without all the superfluous parts (e.g., the pesky “-erature"). While a body without organs may be a perplexing and possibly grotesque image, it remains a vital one to developing a minor lit. Like a human body emptied and even the disappearance of the skin itself, our largest organ, ceases to function as a body at all, minor lit draws attention to forces present in children's and adolescent literature that work to erase its constituent parts: children, adolescents, and literature.

\section{On Becoming Minors and Minorities}

But then what does it mean to call a lit minor? To address this point, I refer first to Deleuze and Guattari's account of becoming to explain how children and adolescents become 
minor. They already had childhood in mind when they explicated what becomings are in their work $A$ Thousand Plateaus. They write:

Once again, we turn to children. Note how they talk about animals, and are moved by them. They make a list of affects. Little Hans's horse is not representative but affective. It is not a member of a species but an element or individual in a machinic assemblage: draft horse-omnibus-street. [...] So just what is the becoming-horse of Little Hans? Hans is also taken up in an assemblage [...] it is not a question of imitating a horse, "playing" horse, identifying with one, or even experiencing feelings of pity or sympathy. [...] The question is whether Little Hans can endow his own elements with the relations of movement and rest, the affects, that would make it become horse, forms and subjects aside. $(257-58)$

Becoming is a process of relational change that creates a wholly distinct entity as its result. The example presented is of a young boy's affinity for a horse that leads him to "become horse," a phenomenon with results distinct from what he was before. The form and subject of Little Hans and that of the horse are cast aside. The becoming-horse of Little Hans is then his being subsumed by the affective assemblage of the horse. It is beyond an emotional response but rather, for Deleuze and Guattari, a fundamental change of a machine. Consider then what becomes of young children when they read children's books imbued with affective didacticism (e.g., moral lessons, catchy mnemonics, etc.) and, what author William Toupance theorizes as "a dimension of the text that critics tend to ignore or scant," adult-curated pleasures (177). Consider what becomes of teenagers when they read adolescent fiction, a genre Trites describes as "an Ideological State Apparatus, an institution that participates in the social construction of the adolescent as someone who must be repressed for the greater good" (83). Without falling prey to 
the hard constructivism of French historian Philippe Ariès, who argued in 1960 (with questionable methodologies) that childhood plainly didn’t exist until modern times, or without relying too heavily on the Marxist structuralism of Althusser, which holds that ideology alone interpellates child subjects into existence, the concept of the becoming-reader suggested by Deleuze and Guattari allows us to acknowledge a significant change that occurs when a child or adolescent is, in large part, taken up by an assemblage of children's or adolescent literature, by its machinations, whatever they may be. A minor lit, in this sense, is a wholly new assemblage because it is a lit taken up by the minor. But likewise and importantly, minor lit is a figuration of the minor taken up by the lit. Previous theoretical frameworks have been limited by a one-way consideration of what a major literature can impart to its minor readership, indicating that power and meaning seem to flow out from adult-centered cultural, societal, and ideological encoding, through the hidden adults and ironic narrative addresses and the pleasures deemed appropriate, and then only lastly flowing towards the deterritorialized audience of children and adolescents. I contend, on the other hand, that minor lit allows for a critique of the whole machinery, even speaking to what may flow the other way, from the minority to the majority.

Although for Deleuze and Guattari the terms minority and majority do not represent the racial divisions most familiar to Western discourses today, there are an important number of occasions when that distinction is blurred and race is offered as the most effective example of what a majority is or what it means to become-minority. When speaking of the racial deterritorialization present in the poetry of Arthur Rimbaud, for example, they write:

The revolutionary unconscious investment is such that desire, still in its own mode, cuts across the interest of the dominated, exploited classes, and causes flows to move that are capable of breaking apart both the segregations and their Oedipal applications-flows 
capable of hallucinating history, of reanimating the races in delirium, of setting continents ablaze. No, I am not of your kind, I am the outsider and the deterritorialized, "I am of a race inferior for all eternity. ... I am a beast, a Negro." (Anti-Oedipus 105)

With concurrent tinges of post-racial and white supremacist jargon, this excerpt hints at the many ways race, class, power and the minority position are intertwined, and yet, this passage hints at a belief throughout that desire, especially that which is expressed either through deterritorialized literature or literal psychosis (a deterritorialization of the mind), can offer reprieve from structural repression. That is, just as "Kafka's work is revolutionary in the way it affects the language in which it is effected," minority production has some pronounced impact on the majority (Kafka xvi).

When writing again of deterritorialized language and its appropriateness for "strange and minor uses," Deleuze and Guattari offer another example: "This can be compared in another context to what the [B]lacks in America today are able to do with the English language" (Kafka 17). They later cite Kafka's own diaries with regard to his usage of racialized language: "Almost every word I write jars up against the next, I hear the consonants rub leadenly against each other and the vowels sing an accompaniment like Negroes in a minstrel show" (23). To me, these references to Blackness allude not just to a circumstantial focus on race in the construction of the minority position or the becoming-minoritarian, but also to how Blackness in literary spaces so often functions as minor fodder for cultural production by the majority. Deleuze and Guattari themselves claim: "Bastard and mixed-blood are the true names of race," but this simply fails to account for the undue attention given to Black peoples and not their works (Thousand 379). Ironically, Black literary and artistic contributions, other than exemplifying deterritorialization through a supposed linguistic minstrelsy, often speak directly to minor literature's other key 
characteristics, such as being inherently political and representing a collective value. Philosopher Ron Karenga, when offering his own triptych of characteristics, writes, "Black art, irregardless of any technical requirements, must have three basic characteristics which make it revolutionary. In brief, it must be functional, collective, and committing" (32). The similarities between Black art and minor literature are actually quite canny, since both have a vested interest in their political power.

Nancy Tolson, in her 2008 book Black Children's Literature Got de Blues, goes a step further by enmeshing the unique political power of the blues aesthetic within Black children's literature's receptive frame. She writes in her introduction:

[Black children's literature] has been excluded in discussions that identify the blues aesthetic even though it contains text and visual art that have the same qualities that can be associated with Black folk art tradition. Black children's literature cannot be placed solely in the world of children's literature because much of it contains strong cultural understandings within Black literature. And this literature is overlooked in much of Black "adult" literary venues because it is written for children. So Black children's literature sits between the two yet has the capability to connect to both. It is a bridge builder. (11) Tolson rewrites the hidden adult of children's literature in the face of a distinctively Black context, highlighting how, beyond the aforementioned ironies and paradoxes, Black children's literature is, perhaps predictably, doubly minoritized. Black children's literature borrows from both the forms of its majority white children's literary counterparts and the major cultural understanding of its Black compatriots. Tolson goes on to reveal that even the historical development of Black children's literature in the United States has, in many ways, been overtly 
concerned with the becomings of its target audience throughout times of active political strife and deterritorialization. She writes:

For over two centuries, negative images of Blacks and Black culture within children's books existed. During the late 1920s Black parents, librarians and educators realized that these children's books were detrimental tools for both Black and white children and needed to be removed from library shelves. It was time to examine to create new ones that could be more useful as well as truthful.

Some Black authors, educators and historians began to realize that for a culture to progress so must the literature that will influence the culture's future. During the New Negro era, Black children were targeted by many of the Negro scholars of that time in order to plant the seed of change within them. (17)

Notably, Tolson demonstrates that a majority position in children's literature has existed historically to the detriment of both Black and white children. As the territory of library shelves becomes a theatre of the war for the collective futures of American children, what Black authors, educators, historians, librarians, and parents set about creating—a Black children's literature made with the majority languages of childhood but expressly intended to effect political change in that language - visibly functions as a minor literature that would be recognizable to Deleuze and Guattari. But Tolson, with her special attention to retaining individual identity in the face of collective becomings unique to children's and adolescent literature, suggests that minor literature, as it has been constructed, simply may not be up to the job of engaging the identities of children, who remain minor in more ways than one. That is, Deleuze and Guattari's framework may be ill-equipped for the intersectional minorization of young people. For this reason, I intend to embrace Blackness in this explication of minor lit while offering minor lit still as an 
effectively broad tool of scholarly inclusion and equity. Nevertheless, in regard to minor lit, minor is never simply a substitute for Black children, just as Blackness is never a substitute for the minor position. While a minor lit does offer a unique opportunity to investigate issues of race in children's and adolescent literature, its attention to power, especially regarding language, politics, and valuation, makes it an effective polemic against all oppressions in this distinctive space.

\section{On a Minor Lit's (Im)Possibilities}

The following examples of minor lit satisfy all of the characteristics of minor literature as detailed by Deleuze and Guattari. Each text is "affected with a high coefficient of deterritorialization," whether on the level of language or sociopolitical identity (Kafka 16). Additionally, in each example, "everything in them is political," which distinguishes them from major literatures' individualistic concerns (e.g., "familiar, marital, and so on") and aligns these texts more firmly with the always-pertinent feminist credo the personal is political (17). Similarly, each example "finds itself positively charged with the role and function of collective, and even revolutionary, enunciation" (17). But what separates minor lit from its theoretical predecessor is that, by centering minors, the enunciation now addresses the whole machine of children's and adolescent literature - that is, the power inherent to its majority machinationsand points toward unexpected readings, new epistemic assemblages, in which minor power may be uncovered. I hope to demonstrate this by briefly examining three works of minor literature that remain cornerstones of more than a century of literary canonization, regularly assigned to young readers throughout the United States, but remain largely neglected by children's and adolescent literary scholarship: A Narrative of the Life of Frederick Douglass, The Catcher in the Rye, and The Bluest Eye. 
My first example of a minor lit, Narrative of the Life of Frederick Douglass, an American Slave, was published in 1845 by The Anti-Slavery Office of Boston. The framing and presentation of the Narrative, on the one hand by white abolitionists, including William Lloyd Garrison and Wendell Phillips, who pen the preface and letter of the front matter respectively, and on the other by Douglass himself, establishes a discrete sort of minor as implied author, narrator, and protagonist, especially since Douglass was in his mid-twenties while he carefully authored the story of his birth into enslavement, his coming of age while fettered, and his eventual becoming into freedom. This minor ostensibly requires some legitimization, validation, and even explanation from the white majority. Garrison writes:

Mr. Douglass has very properly chosen to write his own Narrative in his own style, and according to the best of his ability, rather than to employ some one else [sic]. It is, therefore, entirely his own production; and, considering how long and dark was the career he had to run as a slave,- - - how few have been his opportunities to improve his mind since he broke his iron fetters,--it is, in my judgment, highly creditable to his head and heart.

Perhaps unintentionally, Garrison injects some "heterodiegetic" challenge, to borrow from the vocabulary of narratologist Gérard Genette, into Douglass's narrative (Genette 50). That is to say, in Garrison's preface, by reminding readers that what follows is, in his mind, credible enough for a Black man or styled well enough for an ostensible minor, Garrison injects some distinct content—political and purposeful—that almost undermines the content of the primary narrator. Essentially, Douglass is being deterritorialized narratively before his story of physical, bodily deterritorialization even begins. 
The peritextual letter from Phillips also reinforces the minor status at play within a recognizably major language. "I am glad," he writes, "the time has come when the "lions write history. We have been left long enough to gather the character of slavery from the involuntary evidence of the masters" (xv). Here, other than perhaps presenting Douglass as lion-not-human, Phillips notes that for some time the majority depiction of enslavement has been delivered by the slavers themselves, albeit involuntarily. It must be noted that even first-hand narrative depictions of slavery, despite lingering questions of authenticity, were nothing new at the time of Douglass's own contribution. Quobnah Ottobah Cugoano’s On The Evil \& Wicked Traffic Of The Slavery \& Commerce Of The Human Species was a fairly popular text on both sides of the Atlantic Ocean when it was released in 1787, and, published in 1789, The Interesting Narrative of the Life of Olaudah Equiano was, according to Henry Louis Gates, "so richly structured that it became the prototype of the nineteenth-century slave narrative, best exemplified in the works of Frederick Douglass, William Wells Brown, and Harriet Jacobs” (725). Likewise, as Paula Connolly recognizes in Slavery in American Children's Literature, 1790-2010, “children's literature and the figure of the child functioned centrally in debates about slavery, as they have in the literary and visual re-creation of slavery to the present day" (2). So by the time Douglass begins to write his narrative essentially of coming of age while he himself is no older than his mid-twenties, a fully functional, major language of slave narrative has long been established. As a form of major literature, Douglass's Narrative was plainly intended by its abolitionist supporters to be a lively plea for total abolition at most, a subtly plotted exposé on the horrors of slavery with hopes of yielding additional support, maybe some manumission at least. But, as a minor lit, Frederick Douglass's minor position is re-inscribed, and so the enduring political and pedagogical power of his narrative rises to the surface. 
Near the conclusion of his account, Douglass explains why he has elected to omit key details about his escape. He writes:

First, were I to give a minute statement of all the facts, it is not only possible, but quite probable, that others would thereby be involved in the most embarrassing difficulties. Secondly, such a statement would most undoubtedly induce greater vigilance on the part of slaveholders than has existed heretofore among them; which would, of course, be the means of guarding a door whereby some dear brother bondman might escape his galling chains. (59)

Thus the description of Douglass's escape, purposefully obfuscated for the collective benefit of fellow escapees, is one of the significant moments where concerns of narrative cohesion (major literature's investment in details of rising action, climax, and conclusion) are cast aside for an emphasis on discernibly minor, communal concerns. As a minor lit with deterritorialization as its chosen praxis, Narrative of the Life of Frederick Douglass, a Slave may be read as the protagonist enacting his plan to shed his status as territory while moving surreptitiously from one territory to another, just as the narrator treads lightly on uncertain territory of his own to similarly move the reader, as a textual reaffirmation of interpretive impossibilities. Narratively speaking, Douglass decides there simply isn't a language for the details of his freedom, despite the aforementioned framing and his education specifically positioning him to use the major language otherwise. In this sense, I would argue, a minor lit is most predominately concerned with minors in their own terms, however impossible that may be.

Similarly, Holden Caulfield, the main character of J. D. Salinger's 1951 novel The Catcher in the Rye, represents for many readers all that adolescence is on its own impossible terms. As Morteza Yazdanjoo and his collaborators note in their linguistic analysis of the text, 
“The protagonist's idiosyncratic use of language, which represents his supposedly 'rebellious' individuality in a transitory stage of his life, plays a crucial part in delineating his role in the novel" (763). Although Holden is characterized, in large part, by a wealthy, formally educated, Northeastern American upbringing, he uses the associated language of that region, according to Yazdanjoo et al., "in a manner quite different from a WASP," which implies that the WASP signifier can be most certainly associated with a powerful majority (764). It is ostensibly in his distinctive language use — "phony," lousy," "goddamn," and so forth— that Holden becomes most subversively minor, just as it is in its language that this second example of a minor lit most challenges and even affects major interpretations of adolescence (Yazdanjoo, et al., 764).

In an episode in which a weary, drunken Holden confides in his younger sister Phoebe toward the end of the novel, Salinger offers a titular justification in the form of reflection on the minor position. He writes:

I was thinking about something else—something crazy. "You know what I'd like to be?" I said. "You know what I'd like to be? I mean if I had my goddam choice?" [...] "You know that song 'If a body catch a body comin' through the rye'? I'd like-" "It's 'If a body meet a body coming through the rye'!" old Phoebe said. "It's a poem. By Robert Burns.” [...]

She was right, though. It is "If a body meet a body coming through the rye." I didn't know it then, though.

[...] "Anyway, I keep picturing all these little kids playing some game in this big field of rye and all. Thousands of little kids, and nobody's around—nobody big, I mean-except me. And I'm standing on the edge of some crazy cliff. What I have to do, I have to catch everybody if they start to go over the cliff-I mean if they're running and 
they don't look where they're going I have to come out from somewhere and catch them. That's all I'd do all day. I'd just be the catcher in the rye and all. I know it's crazy, but that's the only thing I'd really like to be. I know it's crazy." (223-24)

How Holden is able to use Robert Burns's poem parallels well the "strange and minor uses" Deleuze and Guattari predict for a minor literature (Kafka 17). Because it is a minor lit, the text is able to outline the impossible parameters of the minor position. In becoming the catcher in the rye, a suitably implausible becoming, Holden excludes majority power- “nobody big”- to emphasize childhood and adolescence. The image he describes is appropriately machine-like: catching kids perpetually running over this cliff in a field of rye, returning them to safety, rinse and repeat. Still, parts of this machine recede from interpretation. Holden says twice, "I know it's crazy," which in some ways is as absurdist as Kafka's salesman-turned-monstrous bug. As unthinkable as a body with no organs coming through the rye. Or as unlikely as an authentically adolescent voice in major literatures. Or as unattainable as the expulsion of hidden adults from the field of child's play. The power of a minor lit, as these first two literary examples suggest, is its ability to express an impossible freedom—-from fetters both literal and literary—in decidedly minor terms.

But while Douglass boards a train in secrecy and Holden seeks solace in an imagined field of rye, Toni Morrison's The Bluest Eye presents freedom as a comparably ugly impossibility by focusing on how, as Morrison writes in her 1993 foreword, "the demonization of an entire race could take root inside the most delicate member of society: a child; the most vulnerable member: a female" (xi). If Tolson suggests an aforementioned double minoritization of Black children, Morrison delivers young Pecola Breedlove not as representative but as a unique and singular minor who eschews similar quantification. Throughout the narrative, the 
majority batters Pecola — politically and linguistically, upon her skin, inside her body, within her mind, in her eyes. Morrison explains:

But singular as Pecola's life was, I believed some aspects of her woundability were lodged in all young girls. In exploring the social and domestic aggression that could cause a child to literally fall apart, I mounted a series of rejections, some routine, some exceptional, some monstrous, all the while trying to avoid complicity in the demonization process Pecola was subjected to. (xii)

Morrison's political goals are visibly enacted upon the territory of Pecola Breedlove. Pecola's youth, her race, her "woundability" - effectively the whole of her minor body_-becomes a site for Morrison to critique racial and sexual deterritorializations wholesale. Additionally, through the collective value intended for "all young girls" (but most certainly for all those children in danger of falling apart at the hands of an uncaring, even purposefully destructive majority), The Bluest Eye is a most effective minor literature.

That said, it is only as a minor lit that Morrison's account of rape and death and white supremacy and racialized self-contempt moves beyond its Oedipal configuration of a provocatively wicked father impregnating his daughter, or its metaphorical framing of blue eyes as an affront to racial beauty, or its psychotic conclusion as Pecola's mind is purportedly fragmented by all that she's endured. All of these interpretations rely on staging the narrative as a carefully designed machine that produces distinct political meaning that may be taken from the text by the majority of its readers, and uses the minor at its center as a part to be worked and contorted and even discarded if need be. But in a minor lit Pecola cannot be discarded. That relatively easy — and frankly too possible of a resolution - simply cannot be the takeaway. As a minor lit, the novel's machinery is reimagined to remind us, as Deleuze and Guattari explain, 
"To enter or leave the machine, to be in the machine, to walk around it, to approach it—-these are all still components of the machine itself" (Kafka 7). In other words, if what we take away or interpret remains constituent to the literary machine, the minor that is integral to its power must also be the machine, must also be powerful. And as we again approach the impossibility of a machine with no parts, a body with no organs, an autumn with no marigolds, a young, Black childless mother and siblingless sister with the power to manifest the bluest of eyes, the major must yield completely to the minor and resist the easy interpretations. "One problem," Morrison writes regarding her distinctive machine building, "was centering the weight of the novel's inquiry on so delicate and vulnerable a character could smash her and lead readers into the comfort of pitying her rather than into an interrogation of themselves for the smashing" (xii). This interrogation of the power of the majority remains intact, but, perhaps more important, it is only as a minor lit that, after her parts are so traumatically removed, readers may reclaim Pecola — her language, her politics, her symbolic value — because, unlike many other literatures, minor lit is uniquely invested in the impossibility of her power.

So then, what if Pecola actually has the power to generate her blue eyes? A minor lit reading must ask this question even if an answer is untenable. At the conclusion of the novel, an ending as provocatively strange as it is significantly minor, Pecola pleads with herself not to leave. She's unsure if her newly changed eyes —-"They didn't go away. They changed"- are in fact the bluest in the world and worries that her selfhood will never return to her because of this (193). "Sure. I'll be back," she assures herself, "Right before your very eyes" (204). The narrator goes on to list the many ways Pecola was used by "us"- "And she let us, and thereby deserved our contempt. We honed our egos on her, padded our characters with her frailty, and yawned in the fantasy of our strength" (205). The story of a minority surrendering everything to the 
majority is nothing new, but a minor lit considers earnestly the difference between going away and changing and how Pecola self-affirms a change, while also going away. In her own terms, which is the cornerstone of any minor lit, however impossible those terms may be, and although her community, her father, her peers, and her story have taken so much, Pecola may have an immutable power to get the bluest eyes and ultimately be right before [her] very eyes.

\section{The Body of Minor Lit}

"A theory that cannot be used in concrete text analysis," Nikolajeva remarks, "is like a bicycle with square wheels: radical and daring, but hardly functional (14). This chapter's explication of Deleuzian theory and the subsequent introduction of a minor lit theory is fully intended to be read as radical, perhaps daring. Nonetheless, the primary function of the minor lit framework is to counteract both the "oppressive function" of literature written for young people and the aetonormative position that "[c]hildren in our society are oppressed and powerless" (1617). A minor lit suggests that the reality is more complicated and, because of this, the power of young people can be recovered, realized, and represented by materials often overlooked by traditional children's and adolescent literary criticism. For Nikolajeva, this same power is apparent, even if just momentarily, in carnivalesque forms such as fantasy, where "an ordinary child is empowered through transportation to a magical realm, through the possession of a magical agent, and through the acquisition of a set of heroic traits or magical force, impossible or at least improbable within the existing order of things" (17). In these literary carnivals, the superior power of adults is diminished, while the power of the young is elevated, subverting normative power dynamics. For Deleuze and Guattari, on the other hand, minor power is most potent in the literary contexts of deterritorialization, politicization, and collective value. Their minor literature represents the power of a minor to create within a major language, again 
subverting normative structures of power. Emerging from these theoretical offerings, a minor lit is likewise a subversion of the normative interpretations of power with regard to minor subjects.

Frederick Douglass is a minor deterritorialized in his own writing by the major languages of the abolition movement and the territories of enslavement. Holden Caulfield is a minor subverting majority literatures and conventions to emphasize a specifically minor politic of "nobody big." But Pecola Breedlove, as an assemblage of irreconcilably minor identities and powerful impossibilities - a daughter-lover; an ugly-beauty; an organless body with, still, the bluest eyes in the world; a young, Black, poor, girl in 1940s America—is the centerpiece of what a minor lit is. When feminist Deleuzian scholar Rosi Braidotti, in Metamorphoses: Towards a Materialist Theory of Becoming, attempts to represent the body in terms of "radical immanence," in a way, the problem of discarding or dismissing Pecola rears its head (123). "This means," she writes, "that I want to think through the body, not in a flight away from it" (5). The minor lit framework similarly allows us to think through Pecola's body, not in spite of it.

For Braidotti, reconciling the sorts of intersectional feminisms vital to this work with the theoretical corpus of Deleuze is met with some resistance from those most willing to gatekeep a body of work disposed "to dilut[ing] metaphysical difference into a multiple and undifferentiated becoming" (77). In other words, her research suggests that the very subject of intersectional becoming — or that of becoming intersectional subjects—-has proven to be threatening to those most politically dominant. Braidotti notes, "What seems to be emerging is a disturbing form of masculinism in the reception of Deleuze and Guattari's work" (92). That is to say, while the minor or minority subject is best understood through a series of becomings, and not simply material differences, the material nonetheless matters, especially as we look at who is performing this work. Just as Deleuze and Guattari suggest "a minor literature is much more able to work 
over its material," for the critical lens of minor lit to truly be as inclusive and revolutionary as I envision it to be, its material — minors across the numerous intersecting boundaries and limitations of identity — and the material differences therein must be brought to the surface in ways that many orthodox Deleuzians neglect. But the minor body is one of difference and resistance. It is elusive to majority interpretation and finds its power through its strange and minor configurations. These configurations may look like chattel slavery or prep school rebellion or incest: a train ride to freedom, a rye field, or the bluest eyes in the world. The minor subject, as Braidotti contends, "is not substance, but rather a process of negotiation between material and semiotic conditions that affect one's embodied situated self' (75). And the field of children's and adolescent literature - with its carefully curated semiotic conditions contingent on the material bodies of its audience — is the ideal arena for this negotiation. The concept of minor lit therefore offers the ideal language.

But the concern of being a square-wheeled bicycle remains a real one. Likewise, Braidotti's emphasis on embodiment (instead of the purely discursive), and her resistance to dominantly masculine or overly negative figurations of theory, are certainly admirable and influential to the ideas I express here. For minor lit to be a worthwhile theoretical contribution in contemporary contexts, it must engender work that acknowledges the material realities of its minor subjects, provide concrete text analysis informed by that material, and effect positive change. To put the efficacy of the minor lit framework to this particular test, the following chapter calls upon Black feminist thought and contemporary texts informed by the radical, oftmaligned politic Black girlhood. 


\section{CHAPTER III: ON SEX, FAMILY, AND DREAMING}

We do not, cannot, know the meanings of all their words, for we are nine and ten years old. So we watch their faces, their hands, their feet, and listen for the truth in timbre. -- Toni Morrison, The Bluest Eye

According to the American Library Association's Office for Intellectual Freedom, The Bluest Eye consistently (and impressively) ranks high atop the list of most censored, challenged, and outright banned books in schools and libraries throughout the country. Reasons given for challenging the fictional account of Pecola Breedlove's arrival into the young MacTeer sisters' predominately Black, working-class Ohio community include Morrison's use of “offensive language," her "underlying socialist-communist agenda," the story being "sexually explicit," and, rather tellingly, that it "contains controversial issues" ("BANNED: The Bluest Eye"). On one hand, those familiar with the novel may consider the condemnations proffered by librarians, educators, parents, politicians, and communities from Fairbanks, Alaska, to Buncombe County, North Carolina, valid or even understatements. On another, however, Morrison's invocation of childhood and adolescence in the context of "controversial issues" like race, class, and sex isn't simply provocative but rather is an invaluable reconfiguration of how child subjects may be read both in literature and culture. As adults in charge of schoolhouses and presiding over courthouses, those responsible for call numbers and those most prone to calling in complaints exercise their discretion in determining the appropriateness of The Bluest Eye for young audiences, an imbalance of power is clear. In a novel that ostensibly gives prominence to adolescent perspective and experience, the implication that gross socioeconomic inequity, racial injustice, sexual violence, and/or incest can somehow disqualify the text from being consumed 
by adolescent readers reiterates the powerfully imbalanced ways childhood and adolescence are prescribed.

Much of Toni Morrison's writing suggests prescription about Black girlhood remains especially askew or, again, deterritorialized. At nine years old, Shirley-Temple-doll-hating Claudia MacTeer discovers precisely this when she gripes, "Adults, older girls, shops, magazines, newspapers, window signs — all the world had agreed that a blue-eyed, yellowhaired, pink-skinned doll was what every girl child treasured" (20). Claudia resents the territorial displacement represented by these white baby dolls and their fleshy real-life counterparts until she simply can't any longer, succumbing over time to being like the other brown girls who worship white skin and blue eyes to the best of their brown girl abilities. "Thus the conversion from pristine sadism to fabricated hatred, to fraudulent love," she narrates as she determines to stop dismembering the dolls gifted to her despite not wanting them (23). Claudia, her ten-yearold sister Frieda, and eleven-year-old Pecola spend much of the novel dealing with what adults leave behind for them in overheard, gossip-riddled conversation or the ideological expectations that manifest in silence, and collectively the girls mature, as children may, under one form of duress or another. Soon after Pecola moves in with the MacTeers, for example, she experiences her first menstrual period, and Claudia and Frieda panic, having no idea how to respond to the blood discoloring their new friend's dress. Their mother subsequently steps in, first admonishing her daughters for fumbling between Pecola's legs with swaths of cotton like "nasty girls," then laughing heartily out of eventual recognition of what has happened (30). In considering Pecola after this episode and perhaps as some bit of foreshadowing of what's to come, Claudia comments, "She was different from us now—grown-up-like" (32). But it must be established plainly that within the context of the story, Pecola remains a child despite "ministratin'," despite 
being raped and subsequently impregnated by her father, despite her own child's stillbirth, and despite how difficult it may be for some to reconcile poor, ugly brown girls with Shirley Temple or Dick and Jane imaginings of childhood. But for decades, where adults have challenged the narrative space they inhabit in Lorain, Ohio, Claudia, Frieda, and especially Pecola have been disallowed to be of, for, or with children despite the educational value they continue to hold.

When English teacher and Milken National Educator Award winner Shekema Silveri was asked in a 2017 interview why she continues to teach The Bluest Eye, she responded, "the discussions about race are discussions about why Shirley Temple was an icon for the children in the book." Silveri asserts that literature acts as an artifact to allow her students to explore the world they find themselves within but in which they may encounter barriers to engagement. "After reading the book," she continues, "I had a student who said that she was a product of incest. And I've had a student who said that she was molested by her uncle. Books allow us to help them heal in ways that we as educators couldn't help them heal on our own." Minor lit, as a conceptual framework, supports this goal not only by critiquing the aetonormative power of adults to determine the value, territory, and political boundaries of childhood and adolescence, but by recognizing the potential power of child and adolescent subjecthood to execute its own challenges, to teach, and to heal. So because the previous chapter details a reimagining of minor literature to establish a foundational understanding of minor lit, this chapter will expand beyond the similarities with Deleuze and Guattari's work to explore the minor lit framework's distinct composition within the context of works of literature that foreground childhood and adolescence, using as examples The Bluest Eye, Sula, and Brown Girl Dreaming. Each of these texts - two novels authored by Toni Morrison and the last a memoir written in verse by Jacqueline Woodson — showcase Black female adolescence. And just as the Combahee River Collective 
Statement asserts that "[B]lack women are "inherently valuable," each reading I present is informed by Black feminist thought in large part because the task here is similarly to call into question "some of the most basic assumptions about [Black women's] existence" (273). That is, the minor lit framework, like its forebear minor literature, posits three distinct but equally important challenges to the way children's and adolescent literatures are traditionally read: first, there exists an irrevocably intersectional relationship between sex, race, class, and adolescence. Second, the territory of childhood remains powerfully entangled with that of adulthood in ways that inform both. Last, the language of children's and adolescent literature is distinct not due to an oft-presumed simplicity but because of how attuned it tends to be to the political realities of its audience.

\section{Pecola's Pleasure}

Before being placed in the care of the MacTeer family, Pecola lives in the lower storefront of a two-story gray building across Broadway with her teenaged brother, Sammy; their alcoholic father, Cholly; and their bitterly pious mother, to whom the family refers more often than not as simply “Mrs. Breedlove." Cholly and Mrs. Breedlove's relationship is depicted as graphically violent and convincingly indignant — the two continually war against each other with a "darkly brutal formalism that was paralleled only by their lovemaking" (43). Throughout the novel, Pecola witnesses her parents both coming to blows and in the throes of intimacy, and even as the narration repeatedly establishes both states in generative relation to one another, Pecola consumes these seemingly grown-up images as depressingly personalized lessons on her inherited ugliness. As an audience to their parents' brawls, such as when Mrs. Breedlove chastises a drunken and surly Cholly for neglecting to fetch coal, Sammy and Pecola tend to respond in kind. Sammy jumps into the fray on occasion, curses a lot, or runs away. As for the 
youngest Breedlove, Morrison writes: "Pecola, on the other hand, restricted by youth and sex, experimented with methods of endurance. Though the methods varied, the pain was as consistent as it was deep. She struggled between an overwhelming desire that one would kill the other, and a profound wish that she herself could die" (43). In seeing her parents attempting to destroy one another, and even perhaps destroy themselves, the seeds for Pecola's titular desire for blue eyes and the corresponding destruction of her ugliness are planted. After frying pans are tossed, and flesh is struck, and Sammy is eventually tasked with getting the coal, Pecola hides herself and prays to disappear, squeezing her eyes shut and willing with all her might parts of her body to fade away from existence. "Try as she might," the narrator acknowledges, "she could never get her eyes to disappear" (45). Her eyes, not uniquely but significantly, remain as evidence of her identity as being both a desiring subject and a child being subjected to images of sex and violence.

Above the Breedloves, in the two-story gray building, lives a trio of prostitutes who regularly attend to Pecola in ways no other adults in the novel seem willing. When Miss Marie, the most talkative of the three, tells Pecola, in coded barbs, of their profession and reluctantly of her experiences of love, it's again Pecola's eyes that come alive to make sense of it all. "Into her eyes came the picture of Cholly and Mrs. Breedlove in bed. He making sounds as though he were in pain, as though something had him by the throat and wouldn't let go. Terrible as his noises were, they were not nearly as bad as the no noise at all from her mother. It was as though she was not even there. Maybe that was love. Choking sounds and silence" (57). Pecola apparently longs to be loved despite seeing love marred more often than not by the adults in her life. In particular, she yearns to be loved the same way she envisions blonde-haired, blue-eyed white children to be loved because of their supposed prettiness. Moreover, she often expresses 
the desire to know and understand love as it is practiced and discussed by adults. Readers see some version of this in her consideration of dandelions, which she thinks are pretty. "But grownups say," to Pecola's confusion, "Miss Dunion keeps her yard so nice. Not a dandelion anywhere" (47). Again, as in her home, where Pecola seeks love, she learns instead an individually difficult lesson of ugliness. After using three pennies to purchase candies from a churlish, white store clerk, the narrator reiterates Pecola's education as such:

Outside, Pecola feels the inexplicable shame ebb.

Dandelions. A dart of affection leaps out from her to them. But they do not look at her and do not send love back. She thinks, "They are ugly. They are weeds." Preoccupied with that revelation, she trips on the sidewalk crack. (50)

Pecola's desire to be pretty, which she thinks will therefore help her to know love, presents itself to readers as a curious desire or desirous curiosity, the juxtaposition of which — throughout the novel - manifests in ways both juvenile and bald-facedly grown-up. Pecola takes some solace in her newly purchased Mary Jane candies with the smiling white face, blonde hair, and - againblue eyes pictured on the pale-yellow wrapper. As Pecola's own eyes linger on the blue eyes pictured, Morrison concludes the episode:

To Pecola they are simply pretty. She eats the candy, and its sweetness is good. To eat the candy is somehow to eat the eyes, eat Mary Jane. Love Mary Jane. Be Mary Jane.

Three pennies had bought her nine lovely orgasms with Mary Jane. Lovely Mary Jane, for whom a candy is named. (50)

In this, Pecola's desire - to be and to know both prettiness and love; to consume a little object of that desire (a peanut butter and molasses-flavored objet petit a) — is cast as inextricably sexual and markedly pleasurable. Here the novel asks readers to reconcile a little girl eating candy with 
a little girl reacting orgasmically to what this candy may represent for her as a desiring subject. This may well be, as the ALA has been witness to, challenging for many, but as Joan Morgan contends in "Why We Get Off: Moving Towards a Black Feminist Politics of Pleasure," this reconciliation is of utmost importance to a just and equitable understanding of Black female subjectivities.

Informed by her own experiences as a scholar, educator, and Black woman, Morgan reflects on the "dearth of available language" to account for the political value of the erotic for Black feminist thought; the persistence of a master narrative of Black female sexuality responsible for the "erasure and excision" of pleasure for Black women; and "the pedagogical challenges in teaching students to read pleasure — both in black women's visual culture and their own —when pleasure as an affective response is deemed illegitimate or uncritical" (37). Similarly, as The Bluest Eye exhaustively and methodically illuminates the interiority of Pecola Breedlove, despite presumed ugliness or immaturity or "controversial issues," readings that disregard the immanent sexual politic of that interiority and, as Morgan suggests, all Black female interiority, routinely discount Black girlhood. "While interiority is widely understood as the quiet composite of mental, spiritual and psychological express," Morgan writes, "black female interiority is that —and then some [...] it demands a black feminist reckoning" (37). For Morgan, that reckoning requires taking up the charge from Evelynn M. Hammonds to progress Black feminist thought beyond its relative silence on issues of sexuality. Of Hammonds' critique, Morgan writes:

Referencing an insular, triangulated conversation between historians, literary critics and feminist theorists, Hammonds conceded that black feminism's long-standing focus on the politics of respectability, cultural dissemblance and similar discourses of resistance- 
interventions that theorized black women's sexuality as an accumulation of unspeakable acts or positioned black women in "binary opposition to white women"-succeeded in identifying black women's sexuality as a site of intersecting oppressions. (37)

Hammonds, by way of Morgan, articulates well the space a novel like The Bluest Eye inhabits as a literary representation of the discourses of resistance Black women of all ages have engaged in historically. The pronounced respectability politics of Lorain, Ohio, in the 1930s falls heavily upon the shoulders of every Black character in the novel, the renting Blacks and the "Propertied" Blacks and the "put out" Blacks and "put outdoors" Blacks (Morrison 17-18). Still, realities of disrespect and dissemblance remain uniquely repressive for young brown girls like Claudia and Frieda, who beat up the nosey white neighbor Rosemary Villanucci and chase away the annoyingly high-yellow Maureen Peal to assuage their own feelings of inadequacy. And as Betty Grable, Hedy Lamarr, and Jean Harlow, along with Shirley Temple and the Mary Jane candy girl, all make appearances in the novel as glitzy statements of femininity and implicit (hetero)sexuality, each of the female characters, in ways large and small, must dissemble their selves underneath the weight of these images, unable to articulate an alternative. Again, Pecola's case is notable because of how ill-equipped she is to resist. Early in the novel, upon her arrival in the MacTeer home as a foster care placement by the county, Claudia notes: "She came with nothing. No little paper bag with the other dress, or a nightgown, or two pair of whitish cotton bloomers. She just appeared with a white woman and sat down" (18). But Pecola's case is also notable in that, despite being in some sense heralded into the narrative accompanied by the specter of a nameless and authoritative white woman, she embodies the discourses that Hammonds cautions "reifie[s]s black female sexuality as pathologized, alternately invisible and hypervisible" (Morgan 37). Pecola has been raped and impregnated by her father, who as a child 
was forced to have sex for the entertainment of white men and as an adult married a woman who injured her leg as a child and believed she was irreversibly ugly because of it and so could never see Pecola as anything other than ugly as well. Part of Pecola's sexuality is forged in domestic violence and white supremacy. Part of it is formed in the trauma of her forebears long before she's born. Regrettably, neither route is uncommon. Yet, when Pecola eats candy, it's orgasmic. And, again, at novel's end, when she looks upon her new pretty, blue eyes, she's ecstatic despite the circumstances of their acquisition. In conversation with herself - a mark of her interiority turned inside out and reaffirmed-Pecola remarks:

And you don't have to be afraid of Cholly coming at you anymore.

No.

That was horrible, wasn't it?

Yes.

The second time too?

Yes.

Really? The second time too?

Leave me alone! You better leave me alone.

Can't you take a joke? I was only funning.

I don't like to talk about dirty things.

Me neither. Let's talk about something else.

What? What will we talk about?

Why, your eyes.

Oh, yes. My eyes. My blue eyes. Let me look again.

See how pretty they are. 
Yes. They get prettier each time I look at them.

They are the prettiest I've ever seen. (201)

As discussed in the previous chapter, a minor lit interpretation allows for recognition of Pecola's power, derived from her Blackness, her femininity, her adolescence, and, subsequently, her minor position. Despite major political and systemic opposition, she calls upon minor power to manifest blue eyes. Morgan's pleasure politics, however, reveals how inseparable that power is from Pecola's desire and pleasure and the difficulty inherent to the articulation of this radically liberating power. Pecola's monologue features two interlocutors. Of the two, one insinuates that the sexual assault Pecola faces at the hands of her father may not have been all horrible or devoid of pleasure. The implication is unpalatable for Pecola, even irritating. She quickly navigates away from the topic to focus again on her blue eyes, an easier, if not more digestible source of pleasure. The complexity of her relationship to her own pleasure is representative of Morgan's conviction that too often there exists "a mulish inattentiveness to black women's engagement with pleasure - the complex, messy, sticky, and even joyous negotiations of agency and desire that are irrevocably twinned with our pain" (36). Arguably like many, Pecola is ill-equipped to consider pleasure, but nonetheless she reclaims it by novel's end with and for herself. Echoing the sentiment of Brittney Cooper, "There is no justice for black women without pleasure," it would likewise be an injustice to discount the reality that pleasure informs the identities of Black girls, not exclusively but importantly (Morgan 36).

Consequently, a minor lit necessitates that childhood and adolescence be read in steadfast conversation with race, class, and, crucially, sex so as to reclaim the pleasure deterritorialized by an overabundance of racist, classist, and sexist silence. In considering the Victorian bourgeoisie's sexual legacy, Michel Foucault expands on this when he writes: 
On the subject of sex, silence became the rule. The legitimate and procreative couple laid down the law. The couple imposed itself as model, enforced the norm, safeguarded the truth, and reserved the right to speak while retaining the principle of secrecy. A single locus of sexuality was acknowledged in social space as well as at the heart of every household, but it was a utilitarian and fertile one: the parents' bedroom. (3) Noticeably, as the presumed heterosexuality of adults is legitimized for the purposes of procreation, children remain an implied consequence, yet are curiously delegitimized from any involvement, left subjected to the enforcement of norms but deprived of any truth of this arrangement. Nonetheless, children, by their very existence, maintain a powerfully significant role in sexuality and even the widespread silencing of it. "Everyone knew, for example," Foucault writes, "that children had no sex, which was why they were forbidden to talk about it, why one closed one's eyes and stopped one's ears whenever they came to show evidence to the contrary, and why a general and studied silence was imposed" (4). Foucault understood this silence to be a systematic repression of children, just as Morgan and Hammonds acknowledge silence to be a cornerstone of the erasure of a plurality of Black women's pleasure. The silence surrounding Pecola's sexual encounter with her father and the subsequent stillbirth of her own child — silence from her community and even in conversation with herself—is a deafening challenge to the claim that children have no sex. The Bluest Eye is markedly a novel where little Black girls experience the suffocating silence of adult-sized rumors, hushed whispers, and condemnations about sex and its intersections with class and race. As Claudia recounts Pecola's fate to conclude the novel, she remarks, "Grown people looked away; children, those who were not frightened by her, laughed outright," as if to note how, in the wake of it all, even the cruelty of brave enough children remains the only thing to break the perhaps deeper cruelty of adults' 
silence (204). Claudia suggests they were-we are - all to blame for what happens to Pecola, children and adults, minor and major alike. Still, a key attribute of minor lit as a critical framework is the refusal to allow this silence to continue regardless of how offensive or sexually explicit or controversial or ripe with supposed communist propaganda. The intersections of adolescent subjectivity demand an unfrightened and empowering form of reading.

\section{Daughters and Mothers}

Three years after the publication of The Bluest Eye, Toni Morison's second novel Sula was first published in 1973. The setting of the latter novel overlaps significantly with the former as this novel is also set in Morrison's her home state of Ohio.This transgenerational story spans more than two decades, from 1919 to 1940, with the interwoven lives of childhood best friends Sula Peace and Nel Wright notably housed at the narrative center. High up in the hills of fictional Medallion, Ohio, ostensibly quarantined away from the wealthy white residents of the valley below, is the Bottom, an ironically elevated slum where working-class Black people precariously reside. The Bottom meets its timely demise and is replaced with suburbs and a golf course sometime after the events of the novel, according to Morrison's prologue, "since it wasn't a town anyway" (4). She continues:

[The Bottom was] just a neighborhood where on quiet days people in valley houses could hear singing sometimes, banjos sometimes, and, if a valley man happened to have business up in those hills — collecting rent or insurance payments - he might see a dark woman in a flowered dress doing a bit of cakewalk, a bit of black bottom, a bit of "messing around" to the lively notes of a mouth organ. (4)

For the white outsider and the reader early in the novel, the Bottom presents a superficially jovial, singsongy image of Black life tinged with overtones of feminine performance and 
sexuality, cakewalks and mouth organs. Thematically, these overtones persist throughout the novel in the intersecting characterizations of mothers and daughters, grandmothers and granddaughters, sisters and girlfriends. Still, Morrison warns that despite the accompanying cacophony of harmonicas, laughter, and knee slapping, "it would be easy for the valley man to hear the laughter and not notice the adult pain that rested somewhere under the eyelids" (4). Unlike the valley man, readers of Sula are continually forced to notice this adult pain. But it remains undeniable throughout the novel that this pain, remarkably locatable in the eyes, is not exclusively adult. Sula and Nel are embedded in this pain in adolescence just as their mothers Hannah and Helene, respectively, have been before them.

Hannah is the eldest of three and one of very few people in the Bottom who remembers when her mother Eva Peace had two legs. After her father takes off, leaving three children (Hannah, a sister named Eva but called Pearl, and the youngest named Ralph but nicknamed Plum) and a battered wife behind in a one-room cabin with only " $\$ 1.65$, five eggs, three beets and no idea of what or how to feel," Eva struggles for some time to provide for her family. When baby Plum develops a severe, nearly fatal case of constipation, presumably due to malnutrition, Eva determines to do whatever she can to provide for her children. Hannah is only five when Eva leaves all three children with a neighbor and the promise of returning the next day. "Eighteen months later," as the story goes, "she swept down from a wagon with two crutches, a new black pocketbook, and one leg” (34). A newly moneyed Eva immediately builds a home for her growing family, big enough to house foster children and a menagerie of boarders as well. Toward these adopted children and boarders, especially the male ones, Eva is perhaps more attentive than she is to her own blood. "Under Eva's distant eye, and prey to her idiosyncrasies, her own children grew up stealthily": Pearl marries and moves away at fourteen; Plum deploys 
for the war; Hannah marries, births Sula, becomes a widow about three years later, and returns to Eva's soon after (41). In 1921, Sula is eleven and lives with her mother and grandmother as well as a trio of boys (four, five, and seven years old), all referred to as Dewey for Eva's convenience, and a large, pale-skinned man ironically called Tar Baby for Eva's amusement.

Across generations and despite the pain that accompanies this throughout the novel, the Peace women intentionally surround themselves with men. The narrator unequivocally affirms: "With the exception of [Hannah's father], those Peace women loved all men. It was manlove that Eva bequeathed to her daughters. Probably, people said, because there were no men in the house, no men to run it. But actually that was not true. The Peace women simply loved maleness, for its own sake" (41). This "manlove" is perhaps the legacy that most unifies the three generations of cohabitating Peace women and entangles their respective stories. Eva supposedly shows her immense, almost pathological love of men to her own son when Plum returns from the war a traumatized, erratic, and deeply broken boy. After days of watching him grow thin and Hannah discovering a bent, blackened spoon in his belongings, Eva is once again determined to do whatever she can to save her children. "So late one night in 1921," Eva douses her sleeping son in gasoline and sets him ablaze (47). "Quickly, as the whoosh of flames engulfed him," the narrator recounts, "she shut the door and made her slow and painful journey back to the top of the house" (48).

Pointedly, Hannah witnessing her brother die by fire in 1921 parallels a teenaged Sula watching her mother die by fire in 1923. Eva causes the former, preferring her son die as a man rather than suffer as a boy, which confounds and upsets Hannah, and the latter brings Eva to her knees in contrition, left painfully grieving and resentful of her granddaughter. In the wake of the 
1923 fire, Eva has a clear memory of the events surrounding the death of her daughter, which is described as such:

$[\ldots]$ as she lay on the ground trying to drag herself through the sweet peas and clover to get to Hannah, she had seen Sula standing on the back porch just looking. When Eva, who was never one to hide the faults of her children, mentioned what she thought she'd seen to a few friends, they said it was natural. Sula was probably struck dumb, as anybody would be who saw her own mamma burn up. Eva said yes, but inside she disagreed and remained convinced that Sula had watched Hannah burn not because she was paralyzed, but because she was interested. (78)

If manlove was a unifying factor for the Peace women, a deeper, more vitriolic bond may have been forged in fires of pain and animosity. As children, as adults, and upon their death beds, the women don't quite like each other. They gaze upon each other curiously and are interested in one another, even loving one another to the point of it being difficult to tell the story of the life of one without addressing the parallels and intersections of the others, like a woven tapestry with tirelessly repeating patterns. But the weave is complicated. The year before she dies, Hannah suggests as much to a neighbor questioning her love for her own kid when she says, "Sure you do. You love her, like I love Sula. I just don't like her. That's the difference" (57). A twelveyear-old Sula overhears. She's visibly hurt, but it's summertime and her best friend Nel's call to adventure allows her some reprieve for at least the moment.

Twenty years earlier, Nel's mother Helene is sixteen years old when her grandmother Cecile insists Helene marry a man who would take her from New Orleans up north to the Bottom, suppressing the legacy of Helene's “Creole whore" mother for good (17). Helene's grandmother "raised her under the dolesome eyes of a multicolored Virgin Mary, counseling her 
to be constantly on guard for any sign of her mother's wild blood" (17). Helene's prudent performance of a femininity Cecile would approve of and a sexuality as distant from her mother's as imaginable yields Nel nine years into her marriage, but any pain is effectively shared between mother and daughter. For example, Helene determines she and her daughter would share in an uneasy trip to visit her ill grandmother in New Orleans. Helene has misgivings about returning so close to the whorehouse where she was born and excavating any shame she'd so readily put behind her in Ohio, but any trip down South in November of 1920 for a Black woman and her daughter would feature its own unique humiliations. Hurried and mistakenly, Helene boards a whites-only coach train with ten-year-old Nel in tow and is immediately accosted by the train conductor. Helene is apologetic and both mother and daughter are visibly shaken by the conductor's callous enforcement of the expectations of Jim Crow. Morrison writes of the encounter:

"We made a mistake, sir. You see, there wasn’t no sign. We just got in the wrong car, that's all. Sir."

"We don't 'low no mistakes on this train. Now git your butt on in there."

He stood there staring at her until she realized that he wanted her to move aside. Pulling Nel by the arm, she pressed herself and her daughter into the foot space in front of a wooden seat. Then, for no earthly reason, at least no reason that anybody could understand, certainly no reason that Nel understood then or later, she smiled. (21) Notably, Helene's decision to board the whites-only coach becomes "we made a mistake." A curt rebuke of Helene becomes Nel's brusquely pulled arm. Helene's confounding smile and unwavering pursuit of respectability and decorum establishes for Nel a shared mode of operating through the aforementioned pain of the Bottom. While addressing only the adult with his 
admonishment, the conductor is able to denigrate and minoritize both mother and daughter, entangling the two by way of white supremacy and patriarchy. This entanglement becomes even more prevalent when $\mathrm{Nel}$ is unexpectedly introduced to both her grandmother and greatgrandmother in quick succession. In the home of the woman, now dead, who raised them both, Helene and her estranged mother Rochelle stare at each other for some time with "no recognition in the eyes of either" (25). Morrison writes:

Then Helene said, "This is your ... grandmother, Nel.” Nel looked at her mother and then quickly back at the door they had just come out of.

"No. That was your great-grandmother. This is your grandmother. My ... mother."

Before the child could think, her words were hanging in the gardenia air. "But she looks so young." (25)

Nel is noticeably confused. Some of this confusion is linguistic. The nomenclature of mothers, grandmothers, and great-grandmothers may invite a certain level of confusion, especially when "grand-" or "great"-ness is uncertain. Additionally, Nel is confused by the youth in the face of her newly acquainted grandmother. She sees her mother in duplicate despite the two women looking upon each other as strangers. But when Rochelle gazes at Nel, she remarks to Helene, "Pretty. A lot like you" (26). The three generations of women exist in a triune in this moment, in the wake of a fourth generation. The three women are connected via the same "Creole whore" blood that ultimately keeps them separated. Rochelle addresses Helene and Nel with a francophone-inflected lilt, which Helene translates for her daughter, not quite comfortable speaking the Louisiana Creole herself. After Rochelle leaves, Nel inquires what "voir" means-a go-to phrase of the grandmother she's immediately enamored by but will ironically never see 
again. Helene insists, "I don’t talk Creole," and pointedly makes sure her daughter understands, "And neither do you" (27).

Time and time again, Morrison relies on the story of mothers to tell the stories of daughters and vice versa. A version of this is observable when detailed reflections of Mrs. Breedlove's life undoubtedly contextualize Pecola's. Sula more thoroughly adopts this transgenerational entanglement, upping the ante in a sense. In this, delineations between the adult and the child characters are not completely set aside but the fixity of the lines between them are noticeably made more porous, which is essential to explicating how a minor lit framework functions. The territory of childhood remains powerfully entangled with that of adulthood in ways that inform both. When young Nel returns to the Bottom, as she reflects on the trip to New Orleans and all it yielded, alone in her room, she whispers to herself in the mirror, "I'm me. I'm not their daughter. I'm not Nel. I'm me. Me" (28). Arguably, it is due to this entanglement that she feels the need to assert herself. "Each time she said the word me," the narrator continues, "there is a gathering in her like power, like joy, like fear" (28). For Nel, the whole of her recent trip - the segregated train cars with no bathroom for "colored" women, struggling to squat and pee besides her mother in the tall grass at intermittent stops, the contrasting smells of Cecile's deceased body and Rochelle's gardenia-scented skin, the awkward convergence of greatgrandmother, grandmother, mother, and daughter —all inform who she is as a ten-year-old child. Still, in this multigenerational collage, Nel experiences enough power, joy, and fear to necessitate that she asserts herself as something else. Me. A me that significantly informs who she, Sula, and even their forebears are and determines their ability to overcome the intersectional oppressions they encounter as Black women throughout the whole of their lives. 
Consideration of cross-generational factors within the context of families and communities is key to Riché J. Daniel Barnes' social welfare policy research and activism. In "Policy Doesn't Help Us: Black Feminist Anthropology in the Social Work Classroom," she emphasizes the value and efficacy of performing "family impact analysis," using Black feminism as "a point of entry" (139). In explaining the analytical process and how she incorporates it in her social work classroom, Daniel Barnes writes: "In each case [we look at], we are taught to place those with the least amount of power and resources at the center of our inquiry and then "allow" them to tell us about their experiences. We then build a theoretical perspective designed to interrogate and eradicate oppression and ultimately bring about social change" (139). Family impact analysis entails giving special attention to the most vulnerable, the least powerful, the most minor, and establishing a perspective that centers them while addressing their particular needs and challenges. This works by centering not just individuals but considering their family and their relationships. Despite acknowledging that this framework is "not designed to be a black feminist tool or practice intervention," the value of shifting the analytic focus away from individuals and toward families and their entanglements is, according to Daniel Barnes, that social work clients, "specifically black women and their families, become accurately visible" (143). That is, while visibility may exist on an individual level even for those most conventionally minoritized, the accuracy of that visibility, the images of minor races, minor women, minors broadly are often flawed. Daniel Barnes provides the example of news stories covering the overwhelming number of states that have passed legislation that require recipients of public assistance to be subjected to drug testing. Despite an abundance of statistical evidence to the contrary, Daniel Barnes notes, "The photos and stories that accompany the news reports usually feature black women" (143). Equity, whether in public policy or adolescent literature, 
relies on an awareness of how visibility matters, and accuracy is essential. From a Black feminist perspective, Daniel Barnes proposes a form of analysis that centers women's, "and by extension, their children's and families', everyday lived experiences" (146). In this, scholars, policymakers, educators, and social work practitioners can more effectively address a desire expressed repeatedly in Daniel Barnes's research "to not only make themselves visible, but to have that visibility exist on their own terms and to their own benefit" (146). A family impact analysis evinces precisely this as Nel looks into the mirror, considering family but insisting on me. Similarly, the minor lit framework insists that reading childhood equitably requires consideration of children and their familial entanglements and a centering of children "on their own terms and to their own benefit," which is admittedly easier said than done.

When Sula and Nel first meet, as the story goes, "Their friendship was as intense as it was sudden," almost as if the whole of their families, their histories, their entanglements converge rapidly and necessarily (Morrison 53). The narrator describes it as such: "Their meeting was fortunate, for it let them use each other to grow on. Daughters of distant mothers and incomprehensible fathers (Sula's because he was dead; Nel's because he wasn't), they found in each other's eyes the intimacy they were looking for" (52). In this, these two brown girls-Nel "just dark enough" and Sula "a heavy brown with large quiet eyes"- become not only like sisters with similarly neglectful or absent fathers, but like surrogate mothers and daughters for one another as they continue to facilitate each other's growth (52). Nel and Sula are inseparable in 1922 when they're twelve and first show interest in boys. They concern themselves daily with cute neighborhood boys, racist boys who bully them on their way home from school, and even Chicken Little, a smaller boy in "too big knickers" that Sula accidentally swings into a nearby river. The girls are inseparable until he dies. For the first time, but not the last, their bond is 
shaken but not severed. "Nel and Sula did not touch hands or look at each other during the funeral. There was a space, a separateness, between them" (64). When Chicken Little is buried, however, that space and separateness dissolves promptly, and with fingers laced tightly, the two childhood friends progress from the death of this child toward their adulthoods.

In 1937, after Nel has been married for a decade and mothered her own children, Sula returns to the Bottom with a college degree, scandalous rumors of sexual conquests, and an air of worldliness that most everyone in the neighborhood associates with evil. Nonetheless, as young adults, the two women are again inseparable. That is, up until Nel catches Sula in bed with her husband, Jude. Both in shock and disbelief, Nel herself narrates what she observes in her bedroom that day:

I am just standing here. They are not doing that. I am just standing here and seeing it, but they are not really doing it. But then they did look up. Or you did. You did, Jude. And if only you had not looked at me the way the soldiers did on the train, the way you look at the children when they come in while you are listening to Gabriel Heatter and break your train of thought. [...] And I did not know how to move my feet or fix my eyes or what. I just stood there seeing it and smiling, because maybe there was some explanation, something important that I did not know about that would have made it all right. (105) Morrison's Sula, like The Bluest Eye before it, is elaborately narrated by non-linear storytelling and shifting perspectives. Here, the novel's omniscient third-person narrator gives way to the voice and thoughts of an adult Nel to perhaps do justice to her pain and confusion. Still, her thoughts immediately retreat to her childhood and simultaneously her own children. In seeing her husband naked and entwined with her childhood best friend, she invites the reader to see again her mother Helene on the train to New Orleans, confoundingly smiling in the face of being 
ostensibly stripped of her dignity. Nel is at a lost for an explanation here in 1937 just as she is in 1920 on that trip to New Orleans. She is at a lost in 1940 when a very ill Sula unsatisfactorily explains herself then subsequently dies. She is at a lost again in 1965 when Sula's grandmother forces her to come to terms with her own role in killing Chicken Little and keeping it a secret despite Sula's protests. In the end, Nel cries at Sula's grave, deeply mourning her best friend. The novel concludes with the description: "It was a fine cry-loud and long—but it had no bottom and it had no top, just circles and circles of sorrow" (174).

This circular nature of sorrow, without a bottom or top, is evocative of the cyclical construction of a story that emerges from a rural Black community already destined for destruction, that ends in the cemetery, and that continually loops through generations of pain and loss. These circles of sorrow markedly envelop both children and adults. For the novel, Sula and Nel's complicated relationship exists at the center of the decades that encircle them, their ancestors, and the legacies they leave behind when they're gone. And while it remains important to note that the two are adult women at points, like the bond they forge when they're twelve years old or the inheritances of their foremothers, their stories are inseparably entangled with their childhood and adolescence. As a minor lit, this entanglement invites the sort of family impact analysis Daniel Barnes advocates because of how pivotal it is to focus upon childhood for the accurate and equitable visibility of Sula and of Nel and Sula. That is to say, to effectively read Morrison's novel and see its Black women in all fairness requires a greater attention to childhood itself. On what would become her deathbed, right after seeing Nel for the last time, Sula remarks to no one in particular: "So she will walk on down that road, her back so straight in that old green coat, the strap of her handbag pushed back all the way to the elbow, thinking how much I have cost her and never remember the days when we were two throats and one eye and 
we had no price" (147). Sula draws a contrast between the image of Nel walking alone as a handbag toting adult woman holding onto the resentment of what she's lost and that of a time when they were just children with two distinct voices but notably one eye. The eye is where pleasure may have been obtained for Pecola Breedlove, where pain may have been housed in the Bottom, but where Nel and Sula "had no price." In this, they were their most accurately visible as young brown girls borne from brothels and bigotry, friendship and fire. In a minor lit, childhood and adolescence are inseparable from adulthood but childhood and adolescence, as shown here, help maintain a uniquely powerful eye to accuracy and equity.

\section{Jackie's Dreams}

As previously established, the three characteristics of minor literature, according to Deleuze and Guattari, are that "the language is effected by a strong co-efficient of deterritorialization," that "everything in them is political," and that "everything has a collective value" (16-17). Illustrating the characteristics of a minor lit relies on Black feminist thought largely because of how Black women and their cultural productions have similarly engaged in radical reconfigurations of language, politics, and value. This is due to Black women's systemized oppression by major power structures — including, but certainly not limited to — other less inclusive feminisms. Angela Davis, in her book Women, Race, and Class, contends that, historically, the need for Black feminisms emerged from a lack of accurate visibility of women of color within the language and territory of women's liberation in the 1960s and 1970s. When discussing the demographics of those at the forefront of major women's movements of the time, she writes:

The ranks of the abortion rights campaign did not include substantial numbers of women of color. Given the racial composition of the larger Women's Liberation movement, this 
was not at all surprising. When questions were raised about the absence of racially oppressed women in both the larger movement and in the abortion rights campaign, two explanations were commonly proposed in the discussions and literature of the period: women of color were overburdened by their people's fight against racism; and/or they had not yet become conscious of the centrality of sexism. (204)

Davis uses this demographic history to provide context to the apparent schism between the reproductive interests of women of color and the mainstream, largely white, campaign for birth control and abortion rights. The justifications given for excluding the voices of racially oppressed women rely on essentialist interpretations of women of color-what they might be “overburdened by," what they may or may not be "conscious of." Davis reveals plainly how these biased, exclusionary attitudes have undermined the political value of the experiences, knowledges, and work of women of color. A minor lit and its corresponding theoretical framework exist to reclaim that value in terms unique to the potential of children's and adolescent literature by presenting language that centers children and adolescents. Notably, language is the attribute of literature that is most immediately discernible and therefore most readily denigrated by critics, scholars, and a major contingent of adults who frequently undermine children's and adolescent literature. But the final characteristic of a minor lit is that the language is especially attuned to its political and collective value, not in spite of its perceived simplicity or lack of sophistication but, rather, because of its radical accessibility. That is, Jacqueline Woodson's Brown Girl Dreaming (2014), as this chapter's third and final example of a minor lit, demands to be read in juvenile words, phrases, and structures because this intentional language increases the visibility of its audience, collectively, politically, and in the face of opposition. 
Interestingly enough, the figure of Angela Davis and her work as an activist play a pivotal role in Woodson's adolescent memoir and its verse narration of a young Black girl, her family, and her coming of age and voice in the 1960s. The memoir begins, again, in Ohio, Morrison's birthplace and also Woodson's. "I am born on a Tuesday at University Hospital / Columbus, Ohio, USA —" Woodson declares, in a poem titled "february 12, 1963," "a country caught / between Black and White" (1). The divisive racial climate surrounding her birth—just three months before Black children as young as six were arrested for protesting racial injustice in Birmingham, Alabama; just six months before the March on Washington for Jobs and Freedom and Martin Luther King Jr.,'s “I Have a Dream” speech—isn't lost to an adult Woodson or her first-person narrator, Jackie. The historical backdrop of the Civil Rights Movement is essential to establishing the high stakes of Jackie's identity as minor within the context of her family, her education, and throughout her country. Despite migrating with her family from Ohio to South Carolina and eventually to New York City, early in her life, Jackie develops a deep love of the South — its land, its air, the people and their slow, breathy cadence of speech—even as marches, protests, and riots erupt. Jackie sits at her grandfather's feet as he explains:

Because we have a right, my grandfather tells uswe are sitting at his feet and the story tonight is why people are marching all over the Southto walk and sit and dream wherever we want. First they brought us here. 
Then we worked for free. Then it was 1863 ,

and we were supposed to be free but we weren't.

And that's why people are so mad. ("south carolina at war" 78)

The narrative Jackie's grandfather recounts here, despite its brevity, attempts to summarize the Black American identity and establishes succinctly the rationale behind the fight for Black liberation and civil rights. Throughout the memoir, Jackie's maturation hinges on thoughtful navigation of a language of racial, economic, and gender oppression shared by those around her. The language surrounds her in South Carolina and follows her north to New York. It manifests in the discussions of counter protests she overhears the adults having or the nightly television she watches. In fact, it's on the television screen where Jackie first sets her eyes upon Angela Davis, who shares Jackie's "gap-toothed smile" and speaks seductively of "a revolution going on and that it's time for Black people to defend themselves" (303). It follows then that Angela Davis, for Jackie, represents autonomy, subjecthood, and the possibility of power over this language. As Jackie and her friend Maria emulate Davis's style, walk through the streets with their fists raised in the air, read about her in the Daily News, and imagine a life running away to California to join the Black Panthers, Jackie grapples with the distinct realities of being both Black and a woman in the United States. "Already, there are so many things I don't understand," she admits, "why someone would have to die or even fight for what they believe in" (304).

Effectively, Woodson's young narrator may already realize the value of language as it pertains to a radical Black identity. That is to say, language and how it is deployed holds unique, often injurious, consequence for the political realities of minorities, which simply isn't the case for the language of the powerful majority. This perspective is complementary to bell hooks's 
warning in "Postmodern Blackness" that "white theorists may move in discursive theoretical directions that are threatening and potentially disruptive of that critical practice which would support radical liberation struggle" (365). Woodson's invocation of Angela Davis as a role model for young Jackie represents well this theme that, unlike their white counterparts, Black people, Black women especially, must tread vigilantly into the sociopolitical fray for fear of imprisonment and even death. Woodson's narrator shares with the reader that "The FBI says Angela Davis is one of America's / Most Wanted," simultaneously referencing the dangers of a militant life but also the undeniable value ("wanted"-ness) of Davis and her words (Woodson 304). In her adolescent commitment to Black feminist thought, Jackie challenges what hooks calls the "pervasive politic of white supremacy which seeks to prevent the formation of radical black subjectivity" (365).

Interestingly, both Woodson and hooks place significant emphasis on writing as a means of proactively asserting subjectivity in opposition to oppression. The cultural production of Black people, according to hooks, faces "far greater censorship and restriction" than that of their white counterparts (367). "That creative writing I do," hooks continues, "work that is abstract, fragmented, non-linear narrative, is constantly rejected by editors and publishers" (367). She suspects that editors and publishing houses suppress and exclude her writing in an attempt to manipulate the representation and recognition of Black critical identity, which, in turn, makes writing — critical and creative — even more indispensable to that identity. Likewise, one of the prominent themes throughout Brown Girl Dreaming is Jackie narrating her growth as a writer with great emphasis on its importance to her identity. Early in the memoir, she tells the reader:

I cannot write a word yet but at three,

I now know the letter $\mathrm{J}$ 
love the way it curves into a hook

that I carefully top with a straight hat

the way my sister has taught me to do. Love

the sound of the letter and the promise

that one day this will be connected to a full name,

my own

that I will be able to write

by myself. ("the beginning" 64)

This poem, tellingly titled "the beginning," illustrates Jackie's affinity for her own name, the beauty it holds, and the autonomy it suggests in the context of the written word. Notably, it is Jackie's sister, herself a child, who supports this path toward empowered literate activity. The recurring image of the women in Jackie's life supporting her growth throughout her adolescence is heartwarming and may certainly be representative of a feminist ideal, but, time and again, the narrator reasserts her autonomy. For example, later as Jackie enters into formal education, she compares her initial academic struggles to her sister's successes, and decidedly proclaims, "I am not my sister" (231). In discussing her distinct relationship with reading, she follows this with:

Words from the books curl around each other

make little sense

until

I read them again 
and again, the story

settling into memory. Too slow

the teacher says.

Read faster.

Too babyish, the teacher says.

Read older.

But I don't want to read faster or older or

any way else that might

make the story disappear too quickly from where

it's settling

inside my brain,

slowly becoming

a part of me. ("reading" 237)

In this poem, the institutional expectations of formal education - to read faster and at an older reading level—attempt to stifle Jackie's development, but once again, it's the unique relationship she develops with story and language that must be preserved to ensure her particularly vulnerable subjectivity.

Significantly, this incident occurs in a grade school classroom, a space where the dominant structures and ideology most readily "hail" us all into subjectivity. Consider the ideological statement implicit in the teacher's mandate to read faster and older. "Too babyish," borders on an insult and represents for readers a prime example of major aetonormativity, which tends to link literacy with maturity. Consider now the radical conclusion Jackie makes, boldly deciding that she doesn't want to read as prescribed to her. In this poem, she wages a minor but 
significant challenge on her own terms, in her own minor language. It must also be noted that her language is uniquely constructed. Jackie wants not to do away with the stories or the major language underpinning a classroom literacy lesson. She loves stories, and when she attends first grade, she remarks to the reader, "There is nothing more beautiful than P.S. 106" (171). The Ideological State Apparatus of public school, in Althusserian terms, is visibly secure. Jackie's challenge is simply that if she's going to be a minor subject grappling with a major language, if the stories are going to settle in her brain and become part of her, become her, she needs that process to happen her own way, at her own pace. She wants power over the language, not just for language to have power over her. This sentiment is assuredly informed by Black feminists such as Davis and hooks, while simultaneously speaking directly to the theoretical foundation of what a minor lit is.

Jackie soon after decides she wants to be a writer. Her declaration of authority over words and stories is met with some reticence from her family. In a poem entitled "when I tell my family," she writes:

$[\ldots]$ they smile and say,

We see you in the backyard with your writing.

They say,

We hear you making up all those stories.

And,

We used to write poems.

And,

It's a good hobby, we see how quiet it keeps you.

They say, 
But maybe you should be a teacher,

a lawyer,

do hair...

I'll think about it, I say.

And maybe all of us know

this is just another one of my

stories. (235-36)

The reservation Jackie's family displays, which makes her feel betrayed, is visibly not about her ability, but rather is about the economic realities of being a writer. Plainly, there is a cost to asserting one's self as a writer, a subject with discursive power. Here it's presented implicitly in economic terms but, as represented in the memoir's invocation of the threats Angela Davis faces, the cost may be one of safety and security as well. The cost for a working-class Black woman in the South of the 1960s is simply not the same as those for a middle-class white woman of the same era. The recognition of this intersectional truth is pivotal to Jackie's development, even if recognition doesn't equate to acceptance. Likewise, as in most minor lit, the divergent standpoints of adults and children are once again entangled here as Jackie's poetic form invites an intergenerational dialogue without wavering on her own autonomy. Although this poem ends with Jackie's rebellious admission that she'll be a writer regardless of her family's reservations, the merit of their statements—and that Jackie respectfully listens—cannot be understated.

While Brown Girl Dreaming is, among many things, an autobiographical account of Jacqueline Woodson's adolescent development into becoming an empowered Black woman and 
writer, several haiku, appearing throughout the memoir as numbered and tellingly titled "how to listen" sections, reveal how undeniably important listening is to this endeavor. In the final haiku, "how to listen \#10," Jackie advises herself as she writes:

Write down what I think

I know. The knowing will come.

Just keep listening . . . (310)

Throughout the memoir, Jackie's haiku are direct, yet form-driven and rhythmically roughened assertions of knowledge. The epistemological claim in this haiku is noticeably not definitive but optimistic. "The knowing will come," she promises, "Just keep listening..." (310). The brevity and relative accessibility of Woodson's poetry is undeniably meant to imitate the voice of a young writer and, likewise, young readers. In this sense, this poem can easily be read as an imperative to those young aspiring writers. As a minor lit, however, Jackie's adolescent language has ineluctable political value. In haiku, the cutting of ideas to juxtapose two images is common. Likewise, choosing this Japanese form traditionally intended to represent nature as the subject may be an assertion of Jackie's identity in terms at once transcultural and natural, global but nonetheless housed in a fourth-grade class in a public school in early 1970s Brooklyn. In this haiku, the poetic form is as minor as it is valuable.

In "Poetry Is Not a Luxury" (1977), Audre Lorde makes a compelling case for poetry’s ability to shed light on the unique experience of human subjects in the world. "This is poetry as illumination," she writes, "for it is through poetry that we give name to those ideas which areuntil the poem — nameless and formless, about to be birthed, but already felt" (371). Lorde provides additional consideration of the relationship between experiences in the natural world and the cognitive development of a subject. Aside from simply being delightful to the palates of 
the discerning person or morally consummate, Lorde sees poetry as plainly indispensable to growth, autonomy, and life. Poetry, she argues, "forms the quality of the light within which we predicate our hopes and dreams toward survival and change, first made into language, then into idea, then into more tangible action" (372). In this sequence, poetry is markedly a beginning step to some larger process of material actualization Lorde imagines as distinct from "the sterile word play that, too often, the white fathers distorted the word poetry to mean" (372). It thus follows then that poetry made for children and adolescents — subjects believed to be in the midst of their own beginnings - works in some similar way, drawing some preternatural connection between language, cognition, and the physical world.

In a similar vein, Karen Coats situates children's poetry squarely between the body and language in "The Meaning of Children's Poetry: A Cognitive Approach" (2013). "Children's poetry," she writes, "draws these two heterogeneous realms together in ways that enable children to feel at home in their own bodies as well as in their social, language worlds" (135). Even before birth our bodies and our awareness of our bodies are primed for many of the formal elements we find common in the nursery rhymes, lullabies, and the poetry young children are exposed to-including "the endless rhythms of body-to-body contact" that start in utero or the "lilting, rhythmic" ways adults tend to speak to babies transculturally $(135,136)$. Where for Coats, children's poetry uses language for not only mimetic representation of the outside world but also signification of the body in language as well — through the predictability of repetition, the familiarity of rhythm, the auditory sensations of sound patterns, etc.,-- Lorde puts forward the notion that poetry may consequently move subjects, mind and body, through language and out the other side toward the not yet representable but nonetheless meaningful. "And where that language does not yet exist," Lorde suggests, "it is our poetry which helps to fashion it" (372). 
Along these lines, Woodson's verse memoir, as a minor lit, successfully positions her accessible poetry not as just valuable to childhood and the "transition from being a body in the world to being a body in language," as Coats writes, but inseparable from childhood and representative of a uniquely political subjectivity—realized in language, embodied materially, but able to traverse or perhaps transgress both (134).

\section{Minor Conclusions}

In summation, the three key characteristics of a minor lit are as follows: an irrevocably intersectional relationship between sex, race, class, and adolescence; an entanglement of childhood and adulthood in ways that inform both; and language attuned to the political realities of its audience. All children's and adolescent literature may not satisfy these criteria, but the intention of this framework is plainly to compel critical readers to consider what would happen if they did. What if proximity to supposedly controversial issues, such as sex, race, and class, couldn't disqualify subjects from childhood or adolescence? What if the accurate visibility of young peoples and their adult counterparts could be better achieved by refraining from hastily separating them from one another? What if the books that center childhood and adolescence were earnestly cherished like the so-called major literatures? While every work of children's and adolescent literature will assuredly not be a satisfactory minor lit, reading critically as if they all were, however, establishes an effective vocabulary for critics to pursue equity for those most historically marginalized. Black and brown girls, ugly children, poor children, and the discomforts of their sexualities, their transgenerational traumas, their families - the Breedloves, those who live in the Bottom, the Woodsons - the dreams have all been forcibly made invisible for too long, with inadequate language made available for those dreams to come into the light. A 
minor lit reading provides illumination. In "Mirrors, Windows, and Sliding Glass Doors," Rudine Sims Bishop writes:

Books are sometimes windows, offering views of worlds that may be real or imagined, familiar or strange. These windows are also sliding glass doors, and readers have only to walk through in imagination to become part of whatever world has been created and recreated by the author. When lighting conditions are just right, however, a window can also be a mirror. Literature transforms human experience and reflects it back to us, and in that reflection we can see our own lives and experiences as part of the larger human experience. Reading, then, becomes a means of self-affirmation, and readers often seek their mirrors in books. (ix)

Bishop thus speaks eloquently to a power inherent within literature to make both the external world of human experience and the inner self visible, but the lighting conditions are too rarely "just right" for many young readers. And because all the various forms of light have been overwhelmingly controlled by major forces of cultural hegemony, many minors continue to be hurt in the dark. In this, minor lit is primarily a theoretical framework dedicated to healing. To this end, the next chapter considers the ethical praxis afforded by bringing minor power to light. 


\section{CHAPTER IV: ON TEACHING MINOR FOLK}

(Silence)

-- My students

When I teach, I tell stories. As an icebreaker, I sometimes tell my students stories about myself as a reluctant reader growing up in Queens, New York, with a secret affinity for Encyclopedia Brown and only Encyclopedia Brown. In an exaggerated, "back in my day" pose, I recall the black-and-white line drawings and the weathered library binding with missing cover images that allowed a younger me to inaccurately imagine Encyclopedia—real name Leroy—as having brown skin like my own, instead of just being Brown. Still, whenever prompted by a teacher or the promise of a Book It! pizza, I took a lot of comfort in the near dozen mysteries economically squeezed into each book. Even my most professedly not-really-a-reader undergraduates share similar experiences, replacing Encyclopedia Brown with Junie B. Jones or the Magic Treehouse troupe. They recount tales of newly minted library cards and Scholastic sales and early book report successes: stories of stories that made literature accessible, challenging, and powerful to us as young readers.

Likewise, my students also hear a lot about my nieces and nephew, who continue to have a comparatively easier time finding characters that look like them partly because they are much more likely than I was to actually look for books and partly because children's literature has evolved a lot since my day. That is, in ways rewarding and commercial, subversive and hegemonic, inspiring and didactic, the stories that fall beneath the umbrella of children's literature as well as the stories of the field itself and the peoples embedded in it continue to develop. In this regard, minor lit is theoretically a way to engage these stories while allowing 
scholars, educators, librarians, parents, and communities to remain diligent about the power of this development process.

This chapter thus offers perspectives on the stories we teach and also considers how we may reframe that power. In my literature classroom, I tend to offer narrative pairings to drive home a point and bridge perceived generational, cultural, and/or regional gaps. When reading Frances Hodgson Burnett's $A$ Little Princess (1905), for example, I ask students to consider varied versions of Cinderella and even, more recently, Meghan Markle, Duchess of Sussex, to discuss ideologies surrounding princesses and, in turn, girlhood, morality, and wealth. We look to literary texts and the oral tradition and the real world to inform one another. This chapter will do the same to showcase the value of considering minor power in the teaching of children's and adolescent literature. The argument here is that the continued evolution of children's and adolescent literature relies on attending to the politics of power in the stories we teach-e.g., the major power to teach stories that may variably celebrate or erase an identity and the minor power to find brownness in unexpected places—such as an Encyclopedia Brown book. Likewise, when we incorporate the minor lit framework into pedagogical praxis, it becomes apparent that remaining diligent about minor power is an ethical issue and the stakes here are higher than we tend to acknowledge. To this end, what follows is a critical examination of stories of young people in grave danger: the divergent fates of Little Red Riding Hood in lore, the real-life assassination of Emmett Till by white supremacists, and Mildred D. Taylor's award-winning novel Roll of Thunder, Hear My Cry (1976). The stories are then placed in conversation with my own teaching practices and the ethical obligation to do better. 


\section{Why We Tell This Story}

Once upon a time, as the story often goes, a girl sets out to visit an aging grandmother. Sometimes her mother warns her not to stray too far from the path, advising prudence and caution in the young girl's journey through the potentially dangerous wood. Sometimes, no warning is given, simply a destination and perhaps a basket of items for the young girl to carry. Sometimes the basket holds foodstuff like cakes, cheeses, and breads. On occasion, a crimson red cap sits atop the young girl's head, but quite frequently she wears a striking red hood. Regardless, the red becomes almost as indispensable to the little girl's story as her little-ness and girl-ness. In prominent English-language variants, influenced by German and French tellings, the protagonist is infrequently anything other than a young woman in red, and over time, the red emerges as titular despite being once considered a color infrequently worn by "morally upright women thanks to its sinful symbolism" (Heiner). This story is, after all, a moral tale. Eventually, the narrative manifests a dark, imposing, masculine threat as an antagonist in sharp contrast to the professedly lily-white, little girl in red. Throughout much of the oral tradition of European variants of the tale, an anthropomorphic wolf serves the role as villain. He may viciously eat the grandmother and granddaughter whole, eat the former and get foiled by the latter, get violently skinned alive by a traveling huntsman, but will always perform his didactic function in ways comical, gruesome, and/or nonsensical depending on the teller and the audience at hand.

"Once told around the fireside as entertainment for adults," according to Maria Tatar in The Hard Facts of Grimms' Fairy Tales, this familiar tale of the little girl in red "featured a trickster heroine who did not have to rely on a huntsman to liberate her" (199). One version "shows Red Riding Hood performing a striptease, then asking if she can go outside to relieve herself before getting into bed with the wolf. Once she gets outdoors, she runs back home, 
outwitting the Gallic predator" (Tatar 199). Charles Perrault in France and the Brothers Grimm in Germany eventually transmute the familiar threads of lore into printed literatures and "excise the ribald grotesqueries of the original peasant tales" (199). The story is distilled into what many today have been exposed to in varied forms. Whether via stage adaptations, picture books, or lipstick commercials, the story tends to go like this: the girl, the color red, the wolf, the threat, and therein some supposed meaning manifests. The world outside is dangerous, the story suggests, especially for young girls, perhaps especially for young girls adorned in the color of blood. The world is dangerous because male threats lurk in the shadows like wolves. This heteronormative reality is presented as being as natural as the woods themselves or the aging of grandmothers. Likewise, the story of Little Red Riding Hood is a story of a little child and over time has become associated primarily with children.

When Clara Doty Bates retells the story of Little Red in 1883, she even begins with a direct address to American children: "If you listen, children, I will tell you the story of Little Red Riding-hood" (5). In this illustrated version, Doty Bates doesn't write of the sexual predation that remains sublimated in the folklore. She doesn't address an audience of mothers, grandmothers, absent fathers, and potential wolves that are likewise characterized in the narrative. In creating a literature for children from this story that has existed for centuries across cultures and peoples, Doty Bates carefully chooses language and decides upon revisions that rely on major ideologies surrounding being little. Despite or perhaps because of this, the story of Little Red Riding Hood still manages to typify the political and minor nature of childhood, where red caps or hoods may hint at some sexual development of young women, but it's white femininity in particular that is venerated and worth saving; where both young girls and elderly women alike may be entangled in the belly of male predators; and where, regardless of the specific details of the story, the 
language of how it is told speaks directly to why and to whom it is told. Folklore and children's literature overlap frequently, which is why it should be no surprise that folklore and minor lit readily intersect as well and allow for productive re-readings of varied lores and diverse folks. But investigating why we hold onto Little Red Riding Hood, continually tell and teach this and folk stories like it, provides a pedagogical context to the minor lit framework as well as the stories themselves.

"In the past and even in the present," as established by Alan Dundes in "The American Concept of Folklore," "there has been considerable disagreement among folklorists as to the nature of folklore" (226). That is to say, the way scholars tend to look upon and theorize the unique dissemination of folk materials (e.g., narratives, music, language, beliefs, and practices) remains as politically contentious as the issue of who gets to be considered folk. As an example, according to Dundes, "American students of folk music do not normally include the music of the American Indian in their studies. This is in marked contrast to American students of the folktale who do include American Indian tales in their studies" (228). A rationale behind this may lie in examining the genesis of the American Folklore Society and the Journal of American Folklore, both founded in 1888 by William Wells Newell. In presenting the goals of the organization and its primary publication, Newell "echoed the European concept of folklore as survivals from a time long past" and, in doing so, implicitly omitted the possibility of folk productions — namely that of "the Indian tribes of North America" and "Negroes in the southern States of the Union"persisting into the present day (Dundes 228). Supposedly then, folklore is what civilized peoples have inherited that is often "coextensive with oral tradition" (229). But, for Newell and many of his contemporaries, not-yet-civilized peoples, like Native and Black Americans, believe in mythology, the "living system of tales and beliefs which, in primitive peoples, serves to explain 
existence" (228). The distinction, which remains at the foundation of many literary, anthropological, and cultural disciplines is markedly racist, but also suggests, as Dundes notes, "that mythology was living while folklore was dying" (228).

This interpretation holds that mythology and folklore are distinct but inseparably linked in that the former may hold ontological value for primitive folk, but the latter survives the primitive to become a tool for supposedly civilized successors to illuminate their past. Even when William J. Thoms first coined the term "Folk-Lore" in a letter dated August 12, 1846 (but published ten days later) the connection to mythology was apparent. Thoms had been thoroughly enamored with the work of Jacob Grimm, especially his treatise Deutsche Mythologie, and hoped to incite similar efforts in England when, to the editor of a British weekly, he writes:

Your pages have so often given evidence of the interest which you take in what we in England designate as Popular Antiquities, or Popular Literature (though by-the-bye it is more a Lore than a Literature, and would be most aptly described by a good Saxon compound, Folk-Lore,- - the Lore of the People) — that I am not without hopes of enlisting your aid in garnering the few ears which are remaining, scattered over that field from which our forefathers might have gathered a goodly crop. (Emrich 361)

For Thoms and the folklorists born from this letter, the goal is the collection and cultivation of the pieces of some valuable, past-oriented puzzle of identity. This is a noticeably nationalist endeavor for Thoms, as he covets the value Grimm's work has brought to German identity and culture by way of facts, "which trifling in themselves, become of importance when they form links in a great chain" (362). English folklore in particular was alleged to be this great chain and managing to communicate this chain into existence would supposedly benefit not just England. "The connexion between the Folk-Lore of England," he suggests, "and that of Germany is so 
intimate that such communications will probably serve to enrich some future edition of Grimm's Mythology" (361). Still, the mythologies of the Germans, while constituent parts, are noticeably distinct from the lore of the Germanic Saxons and therefore English folklore. Germans aren't quite folk or representative of the People for the Englishman Thoms, just as Native and Black Americans aren't for Newell later in the century and across the Atlantic.

Evidently, the American concept of folklore is largely shaped by the English and the imperialist attitudes implicit to their so-called great chain. American folklorists, according to Dundes, "appear, by and large, to have been imitators rather than innovators" (238). So just as "folk-lore was conceived of as a historical science" in nineteenth-century Europe, the overwhelming emphasis on reconstructing the past by way of the cultural and political ideologies of the present becomes an easy adoption of folklorists throughout the United States up into the twentieth century (240). Via revivals, retellings, textual composites, and conscious manipulations, folklore is able to serve purposes ranging from the educational to the capitalistic to the propagandizing. In considering again Little Red Riding Hood and Clara Doty Bates's famed legacy of versifying and re-imagining classic folk stories, these purposes seem squarely focused on American children. In his 1947 essay “On Fairy Stories," the British J. R. R. Tolkien notably claimed the association of children and fairy- and folk stories is "an accident of our domestic history" (4). He writes that these well-worn stories are to be looked at like old furnishings and knick-knacks that were once thoughtfully built for the civic and psychological use and function of humans, not specifically young or old. Over time these stories had been collected in the attics and garages of a domestic culture and these spaces, in turn, have become playrooms. These stories are associated with children today, he suggests in "On Fairy Stories," "naturally, because children are human and fairy-stories are a natural human taste"; but 
nonetheless "accidentally, because fairy-stories are a large part of the literary lumber that in latter-day Europe has stuffed away in attics" (5). This "literary lumber" is notably the material of the structure of European culture and ideology, and again the lumber has been deployed for cultural construction in the United States. But just as Tolkien insists that children only accidentally happen upon this lumber hidden away in attics, Doty Bates and many others have continually brought children to the attic to meet Little Red Riding Hood in ways that highlight the political value of these ostensibly trivial—or even minor-stories.

According to Dundes, the American concept of folklore has over time shifted to include "both historical and psychological perspectives" (242). That is, the scholarship of folklore is no longer a backwards facing account of regional variants and origins, but almost serendipitously as these stories have found their ways to playrooms and the young people therein, possibilities have opened to the relationship these stories have and continue to have with culture at large. Little Red Riding Hood, as folklore, has some psychological connection to the little folk who read her. And just as contemporary folklorists interpret the term "folk" to be "any group of people whatsoever who share at least one common factor," the importance of understanding children as their own folk cannot be overstated (Dundes 232), especially in thinking about minor lit. In previous chapters, the unique subject positions of children and adolescents are detailed, their alterity is examined, and power structures are critiqued. Nevertheless, to understand children and adolescents as folk is to acknowledge that being aetonormatively minor is the requisite common factor they share. Tolkien's assertion that, historically, young people have happened upon the storied furnishings of our cultural attics by accident is incomplete. It seems important to acknowledge the psychological perspectives of these folk of the attic, many surely coerced to that place by major forces, and yet to also retain the minor power inherent to their distinctive 
lore. That Little Red Riding Hood is a children's story is its strength. The story tends to teach that being little places you in danger. Certain colors may place you in danger. The danger isn't always apparent. And although you can be saved or even potentially save yourself, in that Little Red Riding Hood is folk lore, the danger is unique to minor folk. As a minor lit, I contend that we as educators tend to employ these stories both to warn and to teach of a danger that we likewise have an ethical responsibility to address.

\section{Why We Tell This Story to Some Kids and Not Others}

"Compared to other forms of terror and intimidation that African Americans were subject to under Jim Crow," writes historian Amy Louise Wood, "lynching was an infrequent and extraordinary occurrence" (1). Wood cites author Richard Wright's reflections on his youth to emphasize that it may be precisely because of this relative rarity that lynching assumed this storied symbolic significance. Wright recalls:

The white brutality that I had not seen was a more effective control of my behavior than that which I knew. The actual experience would have let me see the realistic outlines of what was really happening, but as long as it remained something terrible and yet remote, something whose horror and blood might descend upon me at any moment, I was compelled to give my entire imagination over to it. (Wood 2)

In this, Wright feared the specter of lynching, its representation in images and stories, the spectacle, more than the thing itself. Despite a long, global history as an extortionate form of punishment independent of any formal legal system, lynching in the United States has been notoriously racialized and the spectacle inseparable from the national discourse surrounding race. So while lynching is an inherently "public and visually sensational" form of fatal violence, according to Wood, inflicted by mobs or individuals in pursuit of alleged or supposed justice, 
white mobs historically performed lynchings for other whites (1). The act necessitates certain rituals and performances and representations like a stage play meant to impart a message of "white power and black degradation, of white unity and black criminality" (Wood 2). Lynchings don't simply tell a story; they are a story in ways that recognizably mimic the dissemination of other folk materials. Lynching has historically relied on folk spectacle: the gathering of crowds, the traditions, the divergent narratives that emerge, the accompanying photographs, films, and media.

Still, accurately identifying the folk proves difficult at times. While the overwhelming majority of lynchings throughout the United States at the turn of the twentieth century occurred in southern states and were perpetrated against Black men, according to Wood, "[lynch mobs] also attacked white men; Native Americans; Chinese, Mexican, and other immigrants; and African American women in significant numbers" (3). And while many white spectators of lynchings "cheered, hooted, clapped, grabbed souvenirs, and, at times, participated," witnessing such an event was a distinct phenomenon (11). Wood asserts that a "spectator or a bystander becomes a witness when his or her spectatorship bears a legal, spiritual, or social consequence; when it can establish the true course or meaning of an event or action; or when it can confer significance or value on an event" (4). Suffice to say, spectators would see a body being desecrated, hear the roar of the crowd, and if that body were burned, may have even smelled it and felt the heat, but Black folk witnessed a lynching wholly differently than white folk.

In the wake of the Civil War, through word of mouth, newspapers, photographs, and eventually motion pictures, the storied spectacle of lynching circulated nationwide even as the South became widely considered, as journalist and white supremacist H. L. Mencken deemed it, "the lynching belt" of the United States (Wood 4). This allowed lynching to function markedly 
as the prevailing story of racial oppression in the country and its retellings to terrorize AfricanAmerican witnesses with violently powerful imagery. According to Wood, photographic and film reproductions of lynching "lent the authority of both divine truth and irrefutable proof to white supremacist ideology" and solidified a sense of "superiority and solidarity among otherwise different white southerners" (5). In turn, however, these same reproductions would be used by African-American communities and antilynching activists to convey and teach alternative truths about lynching; hoping to force white Americans to take moral and social responsibility while simultaneously warning Black Americans of the inherent brutality of white supremacy. In her book On the Courthouse Lawn: Confronting the Legacy of Lynching in the Twenty-First Century (2007), Sherrilyn Ifill speaks to some of the "pragmatic ways" Black folk throughout the country adapted to the stories of lynching when she writes:

A deep well of suspicion was created in the black community. White coworkers, a white boss, or fellow waterman could have been part of the lynching crowd. And even if they had not been part of the crowd, they would [...] "keep quiet." Blacks became more cautious, more insular around the whites with whom they worked and interacted $[\ldots]$ Black parents were teaching their children to walk carefully and to trust no whites (71). Inherently and viciously divisive, lynching stories became moral stories, became cultural stories, and ultimately served as stories pointedly told to Black children.

Despite documentable difficulties in ascertaining records, the Equal Justice Initiative's ongoing storytelling project "Lynching in America: Confronting the Legacy of Racial Terror" claims more than 4,000 African Americans were lynched across the South between 1877 and 1950. "Terror lynchings," the project and associated report assert, "peaked between 1880 and 1940 and claimed the lives of African American men, women, and children who were forced to 
endure the fear, humiliation, and barbarity of this widespread phenomenon unaided" (EJI 3). In this, children were notably among the victims and countless more were undoubtedly witnesses to the grotesque violence. Five children were left "wounded and traumatized" when in 1898 "a white mob in Lake City, South Carolina, set fire to the home of the Baker family and riddled it with gunshots," killing their father and infant sister (EJI 51). In 1933, when Elizabeth Lawrence was assaulted by a group of white schoolchildren in Jefferson County, Alabama, she was subsequently lynched by an angry mob for the audacity she showed in reprimanding them. Her small son Alexander, according to the Equal Justice Initiative, sought the arrest of his mother's murderers, but would have to flee Alabama altogether out of fear for his life. Likewise, the Equal Justice Initiative argues white children socialized in the "culture of violence" were also "psychologically damaged" (EJI 63). "Boys especially were expected to actively engage in lynching," their report suggests, "their roles expanded as they got older until, as young adults, they took on a direct role in the torture and murder" (70). "White children, now elderly, who witnessed these lynchings" according to Ifill's account, "experienced a unique trauma reinforced by years of silence within their families and communities" (8). That is, time and time again, American children and adolescents remained firmly within the orbit of these national horror stories, but the lynching education of Black children and white children remain noticeably separated and deeply unequal to this day.

And then there's the notorious account of fourteen-year-old Emmett Louis Till's lynching in the Mississippi summer of 1955, which I contend gained its notoriety in large part because Till was a child. It's perhaps of no surprise then that as historian Timothy Tyson revisits the events surrounding Till's murder in his 2017 book The Blood of Emmett Till, he refers back to the lynching he witnessed as a child. "I knew the painful territory well," Tyson offers, "because 
when I was eleven years old in the small tobacco market town of Oxford, North Carolina, a friend's father and brothers beat and shot a young black man to death" (2). Again, white folk and Black folk witness lynchings differently, but children may witness lynchings differently still. And as a white child of a Methodist minister "mixed up in efforts to bring peace and justice to the community," Tyson recounts the lynching story of his youth to provide readers a formative rationale as to why he would investigate Till's dishearteningly unremarkable story as an adult as well as the divergent stories of that story, which would become famed in their own right. Tyson writes:

We moved away that summer. But Oxford burned on in my memory, and I later went back and interviewed the man most responsible for [Henry] Marrow's death. He told me, "That nigger committed suicide, coming in my store and wanting to four-letter-word my daughter-in-law." I also talked with many of those who had protested the murder by setting fire to the huge tobacco warehouses in downtown Oxford, as well as witnesses to the killing, townspeople, attorneys, and others. Seeking to understand what had happened in my own hometown made me a historian. (2-3)

A historian is both professionally and etymologically tied to stories, but in this account of what made Tyson a historian, he is notably doing the work of a folklorist, where Marrow's assassins as well as the "townspeople, attorneys, and others" function as folk due to the shared common factor of simply witnessing the spectacle of lynching. He then pulls from these folk, their accounts, their texts, their performances, to construct the lore of Henry Marrow and he performs this same role again in investigating Emmett Till's brief life.

The lore of Emmett Till notably begins in a fashion similar to that of Little Red Riding Hood, with a child being sent on a trip to visit family, not through some foreboding woods 
exactly, but from the Bronzeville neighborhood of Chicago to Money, Mississippi, a rural hamlet firmly in the "lynch belt." Tyson's unique telling, however, starts with Carolyn Bryant (Donham), whom he identifies as once "the dark-haired young woman from the Mississippi Delta," a "backwoods beauty," and a woman who gained global celebrity in 1955 as "a crossroads Marilyn Monroe" (1). Well into her eighties now, sixty years after the assassination of Till at her apparent behest, Bryant tells Tyson a story significantly altered from her original court testimony at the subsequent trial. In September 1955, in a courtroom in Sumner, Mississippi, where Carolyn's at-the-time husband Roy Bryant and his half-brother J. W. Milam stood trial for the murder of a fourteen-year-old out-of-towner, Carolyn's testimony was a centerpiece of the eventual acquittal. The two accused men never testified themselves. Carolyn, on the other hand, spun a yarn about being at work one day in her family store-Bryant's Grocery and Meat Market — when one of the young "Negroes" that tended to congregate on the porch outside the store "almost daily" came inside and nearly assaulted her (52). Like a courtroom sketch artist, Tyson paints the scene:

[...] above the witness stand in the Tallahatchie County Courthouse, two ceiling fans slowly churned the cigarette smoke. This was the stage on which the winner of beauty contests at two high schools starred as the fairest flower of Southern womanhood. [Carolyn] testified that Till had grabbed her hand forcefully across the candy counter, letting go only when she snatched it away. He asked her for a date, she said, chased her down the counter, blocked her path, and clutched her narrow waist tightly with both hands.

She told the court he said, "You needn't be afraid of me. [I've], well, —— with white women before." According to the transcript, the delicate young woman refused to 
utter the verb or even tell the court what letter of the alphabet it started with. She escaped Till's forceful grasp only with great difficulty, she said. (4)

Many of those there that day would leave the courtroom believing that this was a case of attempted rape. Tyson pointedly draws his readers' attention to how prominent the image of pure, vulnerable, Southern white femininity was in this space of alleged justice. "Then this other nigger came in from the store and got him by the arm," Carolyn continued and, unlike what occurred in the store between the two, which only one person survived to tell the story, several witnesses are able to corroborate what happens next. On his way out of the door, Emmett says goodbye. She then proceeds out of the store, across the porch filled with onlookers, to a car to retrieve a pistol. "All agreed," according to Tyson, "at this point Emmett let out a "wolf whistle"' (58). The determination of the all-white jury, judge, and much of the community then was that Carolyn and "the fairest flower" she represented was truly in danger, Emmett was some lustful beast intent on consuming her, and Roy and J. W. were huntsmen-heroes of this strikingly familiar tale of young, white girl victimhood.

The part about being grabbed, the part about Emmett uttering obscenities, key elements of her testimony, Carolyn tells Tyson decades later, weren't true. "You tell these stories for so long," she's quoted as saying, "that they seem true, but that part is not true" (6). Regardless, stories, whether factual or fanciful, spread rather quickly out from that store. One story promptly made its way back to Emmett's temporary Mississippi home, to his hosts, his great-grand uncle Moses and his wife Elizabeth. Emmett begged his cousins not to tell them, mostly concerned that just visiting the Bryants' store at all defied the explicit directive not to go far given to Emmett and his cousins earlier that day and they may ship him on the first train back to Chicago. But "[w]ord was spreading," writes Tyson, and the very next day even a neighbor was 
noted as telling the cousins that she'd heard about what happened at the Bryants' store, warning "I know the Bryants, and they are not going to forget what happened" (55).

A possibly different story makes its way to Roy and J. W. and prompts the brothers to set out with guns to seek out the fourteen-year-old from Chicago, who, through various accounts of the language used at this time, was identified as "the one that done the talking up at Money" or "the one that done the smart talk up at Money" (53). These well-documented remarks imply that the great offense, which ultimately cost Emmett Till his short life, was believed then to be more verbal than physical, more about words said than things done or almost done. This again represents a divergent account from the one Carolyn would give in court a month later, which according to the handwritten notes describing what Carolyn told her attorney initially, had changed multiple times in a relatively short period of time before settling on what would become her testimony in court and what Tyson concludes was "a monstrous lie" (7).

While the relative (de)composition of the tale that led to Emmett Till's lynching is remarkable, an examination of the story of the deadly spectacle itself — one of the most widely impactful of the dishearteningly abundant sort—benefits significantly from a minor lit reading. This is in large part due to three points of note, which overlap with the three tenets of minor lit outlined in previous chapters: First, a disheartening account of the demise of a fourteen-year-old Black boy from Chicago, the presumption of white feminine purity, white male authority, the geopolitics of the South, and other intersectional modes must be considered for us to fully engage the simultaneous novelty and ordinariness of the racial violence Emmett suffered. Second, mother's and son's pain become undoubtedly interwoven in ways that inform how we witness both. Last, the political rhetoric surrounding these events reverberates throughout the country through the veins of the liberation and equality movements of the 1960 s and well into 
the present discourse surrounding racial justice. In her interview with Tyson, Carolyn Bryant, perhaps remorseful, eventually came to a truth that Mamie, Emmett's mother, his family, his community, and innumerable witnesses of the tellings and retellings of this travesty would arrive at immediately: "Nothing that boy did could ever justify what happened to him" (7).

What happened to Emmett Till was a lynching. Plainly. This incident would for many become coextensive with the very term and act as the definitive form of the spectacle for generations. Emmett was kidnapped at around 2 AM Sunday, 28 August 1955 by Roy Bryant, J. W. Milam, and a third unidentified figure. Roy and J. W. were both armed with US Army .45s and reportedly smelled like they'd been drinking. While Emmett was in bed, the two brothers forced past great-grand uncle Moses to enter his home and search for the boy from Chicago. When they found him, Tyson writes:

Now the two white men stood over the blue metal bedstead where the fourteenyear-old boy from Chicago lay with his cousin. "Are you the one who did the smart talking up at Money?” Milam demanded.

"Yeah," said Emmett.

"Well, that was my sister-in-law and I won't stand for it. And don't say 'Yeah' to me or I'll blow your head off. Get your clothes on." Milam told [Emmett's cousin] to close his eyes and go back to sleep, while Emmett pulled on a white T-shirt, charcoal gray pants, and black loafers. (11)

The adult men violently grabbed the child from bed and dragged him out of the house into the pre-dawn Mississippi air. Emmett's family would never see him alive again. It's suggested in various accounts that Carolyn Bryant was outside then to confirm that her kin had retrieved the right boy (Tyson 12). 
In Chicago, Emmett's mother would get a call later that morning with sparse details, but enough to cause her to be distraught. "Emmett was missing," she laments in her memoir Death of Innocence: The Story of the Hate Crime That Changed America (2003, 2011), "Missing in Mississippi. Oh, my God. Oh dear Lord, no. Please, no. Don't let this be happening” (117). Knowingly and tellingly, the news of her son's abduction by white men and the details she received later that morning of his whistling at a white woman already established for Mamie Till (born Carthan in Mississippi herself) the possibility that her son would be lynched. "We knew we had to do something," she recalls, "We kept trying to contact Papa Mose [sic], but we couldn't get through to him. Somehow, we decided to call the newspapers" (118). Mamie's story, in her own words, continues:

A number of reporters came out. I had hoped Mama would know what to say, but she couldn't say anything that would have helped. I stepped forward, I talked to the reporters, I told them the only thing I knew at the time. My son, Emmett Till, had been taken away in the middle of the night by white men who came into my Uncle Moses Wright's home in Money, Mississippi.

I kept hoping that Mama would chime in, but she didn't. She couldn't. I still was holding out hope for a lot of things at that point. I hoped that Emmett was all right. I hoped that whoever had taken him had let him go, or that he had escaped. I hoped that he was only hiding out somewhere, and that was the only reason why we hadn't heard from him. But, as I looked at Mama, I began to realize that she already had given up hope. Mama had lived in Mississippi. Mama knew what it meant when white men came in the middle of the night in Mississippi. She had a look that made me pause. It was the look of someone who could see something she didn't want to see. It was as if she had already 
accepted something I couldn't possibly accept. The unspeakable. She remained silent, and I had to shake it all off. At that moment, I had nothing left but my hope. To let that go would mean I would have nothing. (118-19)

In the historically impactful decision to call news outlets, Mamie, fearful and desperate, and her mother, who had already resigned herself to the eventual outcome, beginto enact publicly what Wood theorizes as a definitive power of the lynching spectacle. Wood writes, "Lynching, indeed, carried cultural force as a form of racial terror through its most sensational manifestations. Terrifying images of white power and black helplessness refracted not only into black homes and communities but across the American racial landscape" (Wood 2). The terror that Mamie and her family felt would not be hers alone. The deep sense of injustice, the loss of hope, the heavy understanding that the lore of the "lynch belt" was real, the monumental cultural force of lynching would be laid bare for all to witness nationally.

"Emmett's murder," Tyson argues, "would never have become a watershed historical moment without Mamie finding the strength to make her private grief a public matter," her personal political (69). Emmett's body was recovered at the Pecan Point cut-off in the Tallahatchie River. The body was bloated, waterlogged, and disfigured. At the trial, Emmett's mother remembers the local Black undertaker Chester Miller testifying to the condition of the body when he arrived on the scene in his ambulance. She writes:

[Miller] saw a hole above the right ear, probably the bullet hole. Part of Emmett's head had been crushed and a piece of the skull had fallen off into the boat. He remembered that. Who could forget seeing something like that? He also described the gin fan and the several feet of barbed wire tied around Emmett's neck. The fan had been brought into 
court, all seventy-five or eighty or ninety pounds of it, and it sat there, like a silent witness or an accomplice to the murder. (177)

Wire or even rope being tied around the neck isn't a lynching requirement, but curiously has been identified as a calling card of it by my African-American literature students whenever the subject arises. Likewise, even via poetic emphasis on the cotton gin fan sitting there in the courtroom, Mamie over and over again describes in her memoir the gruesome details of what happened to her son in such a way to speak directly to the gruesome details of what has been continually and persistently befalling Black sons and daughters throughout the history of this country, from enslavement to Jim Crow to the present.

“Only weeks before the Till lynching," Tyson notes, "terrorists had assassinated Reverend George Lee and Lamar Smith for their efforts to register black voters" (69). The two were shot while driving in Lee's car in Belzoni, Mississippi, only 44 miles from Money. The face of George Lee was mutilated by bullets, but the story remained largely ignored by the media due to how common these occurrences were at this point in history. According to the Equal Justice Initiative, at least 654 reported lynchings had occurred in Mississippi up to that point since 1877 and several more instances of race-based murder still went unreported. Still, community organizers, including Medgar Evers, who was Mississippi’s NAACP state secretary in 1955, had “displayed George Lee's disfigured face in an open casket to great effect” (Tyson 72). A few months later, Mamie would make the same decision. She writes:

This would not be like so many other lynching cases, the hundreds, the thousands of cases where families would be forced to walk away and quietly bury their dead and their grief and their humiliation. I was not going quietly. Oh, no, I was not about to do that. I knew that I could talk for the rest of my life about what had happened to my baby, I could 
explain it in great detail, I could describe what I saw laid out there on that slab at [the funeral home], one piece, one inch, one body part, at a time. "I could do all of that and people still would not get the full impact. They would not be able to visualize what had happened, unless they were allowed to see the results of what had happened. They had to see what I had seen. The whole nation had to bear witness to this. (139) Mamie Till (who authored her memoir as Till-Mobley after remarrying in 1957) adamantly wanted witnesses. She used the open casket funeral in Chicago, local and national newspapers, Jet and Ebony magazine photographers, and television coverage to transmit the image of her son's mutilation at the hands of Roy Bryant and J. W. Milam because she'd determined that everyone had to witness it. It was a moral imperative that the public's judgment of what happened to Emmett Till be cast even before the criminal trial begun. Lynching, in Mamie's hurried but accurate assessment, was a narrative struggle where a minor story could kill a boy, humiliate a family, and quietly and locally reify itself until it happened again. Alternately, if the gory details of what had happened were presented just right, the spectacle of it all could travel the nation, the world, and ignite a powerful fire. A minor lit framework allows witnesses to observe this fire being fueled by the intersectional oppressions that force Black mothers to so regularly and sensationally mourn their children, the politics of adults being mapped onto the bodies and lives of children, and the spectacle of lynching functioning as a determinedly powerful folklore and story of racial injustice.

Mamie was surely not the first person to believe in the importance of this particular storytelling effort. Investigative journalist and antilynching advocate Ida B. Wells spent much of her career in this space. In a conversation with Frederick Douglass in 1894, she draws some distinction between Douglass's work as an orator and her own work. She quotes her response to 
Douglass in Crusade for Justice: The Autobiography of Ida B. Wells (1970, 2020), "With me it is different. I am only a mouthpiece through which to tell the story of lynching and I have told it so often that I know it by heart. I do not have to embellish; it makes its own way" (231). These repeated, unembellished re-retellings of the lost lives of Black folk in the face of the virtual silence of major news and media outlets represents starkly the incontrovertible existence of minor power. Ida B. Wells, identifying simply as a "mouthpiece" for these stories, investigated and documented lynching throughout her professional life when others simply refused, eventually providing much of the foundation for the Equal Justice Initiative's twenty-first century K-12 educational materials regarding lynching. Mamie, realizing that "the nation had to bear witness to this," allowed this material to become lore, to become visualized and visceral for many. After a relatively short jury deliberation — only about an hour with one juror reportedly saying later "we wouldn't have taken so long if we hadn't stopped to drink pop"- the all-white jury acquitted Roy Bryant and J. W. Milam of murder and kidnapping (Tyson 180). The killing of Emmett Till, the very public funeral, and the subsequent miscarriage of justice are widely considered constitutive parts of what would then become the Civil Rights Movement, if not just providing much of the visual, judicial, and ethical narrative that necessitated the Movement. Still, just as the history of the Civil Rights Movement is American history, a question remains about how stories like Emmett's can be better told to all American children, not just Black folk or activist folk or scholarly folk in humanities programs, but Emmett's folk.

\section{How to Tell This Story to Everyone}

Arguably, Mildred D. Taylor's 1976 Newbery Award-winning novel Roll of Thunder, Hear My Cry returns young readers to Mississippi to attempt such a feat. In the novel, nine-yearold Cassie Logan narrates the story of her Black American farming community in rural 
Mississippi during the Great Depression. Taylor presents readers with reliably transparent multigenerational and community-situated relationships throughout all the installments of the Logan Family Saga, but Roll of Thunder, Hear My Cry, with its immense classroom popularity, arguably speaks to issues of educational praxis concerning race, ethics, and childhood. From the first chapter, as the Logan children's derelict school starts in late fall for the Black students obliged to farming duties, to the point when the Logan farm is set ablaze in the finale to prevent a lynching of a young man, the novel's critical evaluation of right and wrong is situated pointedly in terms of its child characters, readers, and their hard-earned education in racial injustice. That is, even as the narrative presents teachers, business owners, community leaders, and friends as morally compromised by Jim Crow era white supremacy, Taylor's novel suggests that young people and their stories remain indispensable to ethical work, both in theory and in practice. Additional to her work as first-person narrator, Cassie - as eavesdropper, overhearer, loyal sister, doting daughter, dutiful granddaughter, good student, budding activist, and adolescent curator of trans-generational lore-is squarely placed at the core of this prized work. Cassie listens intently as her father explains the Logan family's legacy and the complicated sort of ownership she enjoys. Taylor writes:

He took my hand and said in his quiet way: "Look out there, Cassie girl. All that belongs to you. You ain't never had to live on nobody's place but your own and long as I live and the family survives, you'll never have to. That's important. You may not understand that now, but one day you will. Then you'll see.” (7)

Cassie's understanding develops as the narrative progresses. Still, what she learns from the stories she's told, what she experiences first-hand, and the unique reality of being a little Black girl on a farm her ancestors had toiled on as slaves surrounded by as much economic depression 
and racialized violence as white-owned land are all constituent parts of what makes Roll of Thunder, Hear My Cry both potent and remarkable to teach in a minor lit framework. Again, this is a story of intersectional stakes, adult-child relationships, and richly affective political language.

For example, early on in the novel, after a long, tiresome walk down narrow, sunsplotched roads with early-October Mississippi dust billowing around each of the young brownskinned children, Cassie Logan, an otherwise disciplined student, breaks a rule and takes a patently political stand at the severely underfunded all-Black Great Faith Elementary and Secondary School where her mother teaches and her three brothers all attend. After watching her youngest brother Little Man, on his first day of school, refuse the worn and tattered textbook marred visibly by more than a decade of use, and subsequently getting a hard switch landed on his bottom for his trouble, Cassie opens her book to the stamp on the inside cover that must have triggered Little Man. The stamp reveals the racial lineage of their books, which were new in 1922 and assigned then to white students, but by 1933, in a state of obvious disrepair, have been relegated to "nigra" students (25). Cassie tries to defend her brother and explain to the teacher, Miss Crocker, the seemingly obvious apprehensions both children share about being so callously othered by, first, the white supremacist ideologies of the day, then their government, their country, and now by their own school and their only textbooks. Miss Crocker doesn't seem to care. Taylor writes from Cassie's perspective:

This time Miss Crocker did look, but her face did not change. Then, holding up her head, she gazed unblinkingly down at me.

"S-see what they called us," I said, afraid she had not seen. 
"That's what you are," she said coldly. "Now go sit down."

I shook my head, realized now that Miss Crocker did not even know what I was

talking about. She had looked at the page and had understood nothing. (26-27)

The misrecognition in Miss Crocker's face clues both Cassie and readers to the sort of systemic opposition the Logan children face as they attempt to maintain their identities. Still, neither slurriddled textbooks nor the threat of authority diminishes the bond between brother and sister, which reifies narratively the relational bonds that the novel showcases. Cassie elects to receive the switch along with her brother.

Afterwards, Cassie wants to be the one to tell her mother about the incident and take responsibility. "From nine years of trial and error," Cassie reflects, "I had learned that punishment was always less severe when I poured out the whole truth to Mama on my own before she had heard anything from anyone else" (27). Miss Crocker beats her to it though. Still, the conversation with Mrs. Logan doesn't go as Miss Crocker had planned. Instead of praising the teacher for her disciplinary actions and the way she upheld the responsibilities teachers have to their materials, the relationship educators have to the policies that govern them, Mrs. Logan set about pasting paper over the disparagingly racist stamps in each of the textbooks and, in effect, challenging Miss Crocker's standpoint by way of reaffirming her own relationship and responsibility to her children. "Mary Logan, do you know what you're doing?" Miss Crocker expresses, in shock, "Biting the hand that feeds you" (30). Cassie's mother responds coolly with a laugh, "If that's the case, Daisy, I don't think I need that little bit of food," all while Cassie quietly observes her mother continue to cover the stamps of each and every book (30). "I would wait until the evening to talk to her," Cassie narrates; "there was no rush now. She understood" (31). 
Mrs. Logan arguably understands all too well that she can't always protect her children from disciplinary violence rooted in white supremacy, but she will do what she can. She also understands that a beating with a switch, which Cassie and her brother would walk away from, could be worse. The following Sunday, the Logan family learns at church that a young Black man named John Henry Berry has recently been burned to death by a local white family for reportedly being "the nigger that Sallie Ann said was flirtin' with her" (39). John Henry, his brother, and their elderly uncle are dragged from the uncle's home that evening by a mob of white men and set on fire. The uncle and his other nephew survive but both have been left severely mutilated. Mrs. Logan brings her children to take the surviving uncle and his wife food. Cassie describes the scene:

Mrs. Berry took the food, her thanks intermingled with questions about Big Ma, Papa, and others. When she had put the food away, she pulled stools from the darkness and motioned us to sit down, then she went to the blackest corner and said, "Daddy, who you s'pose done come to see 'bout us?'

There was no recognizable answer, only an inhuman guttural wheezing. But Mrs. Berry seemed to accept it and went on. "Miz Logan and her babies. Ain't that somethin'?" She took a sheet from a nearby table. "Gots to cover him," she explained. "He can't hardly stand to have nothin' touch him." When she was visible again, she picked up a candle stump and felt around a table for matches. "He can't speak no more. The fire burned him too bad. But he understands all right." Finding the matches, she lit the candle and turned once more to the corner.

A still form lay there staring at us with glittering eyes. The face had no nose, and the head no hair; the skin was scarred, burned, and the lips were wizened black, like 
charcoal. As the wheezing sound echoed from the opening that was a mouth, Mama said, "Say good morning to Mrs. Berry's husband, children.” (97)

As an educator and mother, Mrs. Logan/Mama uses this house visit as a lived reading for her children. Paralleling Mamie Till's real-life decision to present her mutilated son in an open casket to the world, Mrs. Logan determines that it's important her children come face to face with Mr. Berry. Cassie and her siblings must witness this disturbingly visual text of racialized violence so as to learn that they aren't safe around the Wallaces, the local white family wholly responsible but left completely unpunished, and the Logans may not be safe in general due to the realities of white supremacy. Likewise, the house visit also teaches an implicit ethical lesson of community. This isnt a first or singular visit from Logan family members to the Berry home with food, medicine, or intangible support in tow. Again, the relational ethic in this novel remains enmeshed within its thematic and historical teachings.

Another example may be the difficult lesson Cassie later learns when, during an errand with her grandmother Big Ma, Cassie is shoved onto the ground by Mr. Simms, a white father acting as enforcer for his racist, mean-girl daughter. "When my gal Lillian Jean says for you to get yo'self off the sidewalk," the grown man spits at the brown-skinned nine-year-old laid out on the street, "you get, you hear?" (114). While the incident in and of itself is surely upsetting, what Cassie grieves the most is arguably Big Ma, her grandmother, insisting that Cassie apologize to Lillian Jean. Without fully seeing what Big Ma surely does as a white mob starts to form, Cassie picks herself from the street and continues:

“Big Ma!” I balked.

"Say it, child." 
A painful tear slid down my cheek and my lips trembled. "I'm sorry... M-Miz... Lillian Jean.”

When the words had been spoken, I turned and fled crying into the back of the wagon. No day in all my life had ever been as cruel as this one. (116)

Here Big Ma's understanding of the situation is more developed than Cassie's juvenile one. And while Cassie not feeling understood by her grandmother surely compounds the cruelty of the day, Taylor invokes a sense of intergenerational care in Big Ma's recognition of the overwhelmingly high price of her grandchild's pride. Cassie reciprocates that care with dutiful respect for her grandmother, feigning respect for her oppressors, and, after an explicit conversation with Mama about "the way of things," coming to a complicated, teary-eyed understanding (128). "The way of things" speaks to a sort of folkloric understanding gained from a lifetime of stories like what happened to the Berrys. "That way of things" insists that if Little Red Riding Hood had to look like Lillian Jean, then even Cassie could be deemed a wolf and treated like an animal. That evening, Cassie listens to Mama explain tenderly:

"Baby, we have no choice of what color we're born or who our parents are or whether we're rich or poor. What we do have is some choice over what we make of our lives once we're here.” Mama cupped my face in her hands. “And I pray to God you'll make the best of yours." She hugged me warmly and motioned me under the covers.

Even though Cassie is put to bed, her ethical education is noticeably stirred by the complexity of care Big Ma and Mama show her in these most ostensibly uncaring times. The caring is visibly grounded in their unique relationships, but distinctions between the carer and cared-for 
are importantly collapsed as parental figures show care to a child who not only reciprocates but is likewise given a considerable task in caring for her own terribly vulnerable Black life.

Again, perhaps much of what endures in Roll of Thunder is the unfettered strength and unbreakable bonds within the Logan household. In middle-grade accessible prose, Taylor depicts Cassie and her brothers - the eldest Stacy, the seven-year-old Christopher John, and the youngest Little Man —in generative relation to their Papa and Mama; Big Ma; the relatively militant Uncle Hammer, when he comes down from Chicago; and Mr. Morrison, a burly man down on his luck whom the Logans take in as a farmhand and adopted family member. Readers are invited to experience the ways relationships engender political engagement and learning.

This is beneficial precisely because so many students already— to the chagrin of many educators - engage with texts based largely on their relationship to characters, the relationships between characters, and even how they like or love the text. Many educators are inclined to navigate conversations away from "I like this book because I liked so-and-so character" or "I could relate to so-and-so's relationship to so-and-so" due to the perception that these aren't critical or theoretical enough. In "Literary Theorists, Hear My Cry!" (1992), Jeffrey Willhelm is especially familiar with this phenomenon, using Taylor's text and his own struggles teaching it as a springboard to him positing, "if you don't work to read the text, then everything you do is looking in the mirror" (51). Willhelm then asserts:

Literature is better than a mirror; reading literature should be a unique and powerful way of knowing something new about yourself and about the world. Wayne Booth calls this "imaginative reversals of living" (1983); Kenneth Burke calls it "lived-through experience" (1957). By any name, this is the reading experience I want for my students. (51) 
A two-fold problem with this line of reasoning exists: first, in how it takes a particularly privileged standpoint in the world to so easily belittle the value of mirrors, reflection, and seeing oneself; second, it's unclear how teaching must result in homogenous, one-size-fits-all reading experiences. Perhaps, Willhelm's overall argument for students to learn to read and understand texts such as Roll of Thunder as if in direct conversation with the author is well-intentioned and ethically based in its own right. But a minor lit framework reveals the majority power imbuing this pedagogy and moves educators toward a more equitable form of teaching children's literature. Wilhelm ostensibly would prefer students to develop a seemingly one-sided relationship with the adult author. "To do otherwise," he maintains, "would be limiting and solipsistic" (51). The fact remains, however, that students young and old simply may not want to be part of the "authorial audience" Willhelm suggests, and what they do want cannot be disregarded or made subordinate to so-called literary theories (51). Embracing theorists and critics such as Barthes, Genette, and Eco, Willhelm concludes that "what we read implies a complete world, and this world may be assumed to stand in some intelligible relationship to our own world," but doesn't allow for the possibility of incomplete worlds within a text and the heterogenous relationships readers may develop with them (56).

This last point is analogous to the circumstances of Mrs. Logan's eventual firing from teaching for her audacity to see the incompleteness of the Board of Education-approved literature at her disposal and desiring more for her students than what had been made available for them in our own world. Cassie watches the wealthy white male board members approach as her mother lectures extensively "on the cruelty of [slavery]; of the rich economic cycle it generated as slaves produced the raw products for the factories of the North and Europe; how the country profited and grew from the free labor of a people still not free" (183). Mrs. Logan is fairly consistent as 
an educator in this regard, caring for her students' standpoints as Black children with unique relationships to the history of this country and the precarious spaces they inhabit today, just as she does for her own children. One of the school board member's mocking insistence that "You must be some kind of smart, Mary, to know more than the fellow who wrote that book. Smarter than the school board, too. I reckon," echoes Willhelm's contention that effective reading and learning requires a sort of reverent participation in an authorial audience (184). After Mrs. Logan's dismissal, Cassie reflects, "I had never really thought much about Mama's teaching before; that was just a part of her being Mama. But now that she could not teach, I felt resentful and angry, and I hated Mr. Granger" (185). The lack of consideration for her mother's work expressed here is poignantly childlike, but the relationship Cassie shares with her mother remains a key to unpacking the ethical issues of what's happened, and Cassie responds not theoretically but perhaps like many readers, young and old. We hate Mr. Granger. And admittedly frustrating at times, the phenomenon of readers engaging to texts by way of liking, hating, or relating to them must, in fact, be cherished when that process fosters the potential for learning.

The pedagogical question then becomes how do we expect all readers-again, all of Emmett's folk - to relate to texts that actively attempt to challenge major systems of oppression that may ostensibly benefit them? For example, when we ask white readers to engage with the Logan family, as American educators of all racial backgrounds have done for nearly half a century, a problem persists in that a self-centered relationship with the story is insufficient. Likewise, readers not relating at all would be a disservice to the work, its subject matter, and quite possibly akin to the solipsism Willhelm warns of. In Wendy Saul and Kendra Wallace's qualitative study “Centering the Margins: White Preservice Teachers' Responses to Roll of Thunder" (2002), white adult future educators express some apprehension engaging with 
Taylor's novel, even as they admit to seeing "Roll of Thunder, in particular, as profoundly influencing young readers" (45). Out of 71 white women who took a required course in children's literature and then were asked to generate dialogues about the novel, Saul and Wallace's study found widespread wariness about some of the language Taylor uses-especially the word "nigger" used "judiciously and realistically" — and a "surprising number of the white, preservice teachers chose to focus on the relatively undeveloped but positive white characters, or on the depiction of whites in general" (45-46). Likewise, white readers tended not only to protest the overall depiction of whites as racist but also to insist that (hypothetical) white children "may have their feelings similarly hurt by this vilification of whites" (46). That is, the white respondents to the study, by and large, responded to the difficult racial subject matter of the novel and the complex ethical framework advanced by its narrative "by constructing race as a domain of equal victimization and helplessness-blacks as victims of racism, and whites as victims of unfair, reverse racism" (51). Evidently, not every reading of Roll of Thunder is attuned to the power discrepancies inherent to reading or relating to others, but the minor lit framework affords educators and scholars an opportunity to read, teach, and learn of folk like Cassie or Emmett and better appreciate the transmission of the lore that includes instead of excludes them.

Accordingly, in "Reflections on the Development of African American Children's Literature," Rudine Sims Bishop recalls setting out to "analyze as many of the existing contemporary Black-inclusive children's fiction books as [she] could find," and the organizing principle of her research seems to suggest similar divergences in readings (6). After looking critically at 150 books published between 1965 and 1979, she identifies three categories: "social conscience" books, "melting pot" books, and "culturally conscious" books (Bishop 7). Titles in the first category tend to have white readers as their intended audience, encouraging their 
development of a "social conscience," usually at the expense of thoughtful characterization of Black peoples. "Like the social conscience books," Sims Bishop writes, "most of the melting pot books were written by [white] authors" and tended to ignore any qualities of race other than skin color in their illustrations (7). In a practical sense, these first two categories feature books written and distributed ostensibly not for the benefit of Black children, but for the sensibilities of white readers. Just as the minor lit framework suggests the equitable reading of literature may require an aforementioned attention to power, a minor lit pedagogy requires better attention to the relationships readers can build with a text. Bishop's analysis suggests the slow but eventual development of a body of African American children's literature that prioritizes its readership of all races by addressing their "right to books that reflect their own images and books that open less familiar worlds to them" (9). Despite Jeffrey Willhelm's complete dismissal of the literary value of mirrors and reflection, the last category, where Roll of Thunder is a notable example, "set[s] out to reflect both the distinctiveness of African American cultural experiences and the universality of human experience" (7). In this, Taylor's novel is attuned to equity for all children while maintaining its focus on those children who have been historically considered most minor.

\section{How to Tell the Ending}

At the end of Roll of Thunder, Hear My Cry, when Papa is revealed to have started the great fire that nearly engulfs the cotton fields—white crops, Black crops, and sharecrops alikejust to save a local boy T.J. from a lynching, the relationship that generations of the Logans have had with their land is overshadowed by a quick decision to risk it all. The white landowners turn their attentions to fighting the fire alongside the Black community they've relentlessly antagonized, both sides recognizing in the other their complicated but invaluable relationship to this land. This is very literally where the novel leads us: a tumultuous, yet grounded relationship 
between all parties. Black folk. White folk. Young folk. Old folk. Similarly, in my experience, teaching children's and adolescent literature requires a concerted effort to work over tracts of literary land that remain so conceptually, politically, and culturally rich. My first chapter's exploration of subjecthood, Chapter Two's consideration of power, and Chapter Three's emphasis on the value of minor power are all attempts at cultivating the land of children's and adolescent literature and culture. This chapter explores how to do good with it.

As the titular thunder gives way to the salve of rain and prevents the fire Papa set to the land from consuming much more, Cassie reflects on T.J. She thinks as the novel concludes:

I had never liked T.J., but he had always been there, a part of me, a part of my life, just like the mud and the rain, and I had thought that he always would be. Yet the mud and the rain and the dust would all pass. I knew and understood that. What had happened to T.J. in the night I did not understand, but I knew it would not pass. And I cried for those things which had happened in the night and would not pass.

I cried for T.J. For T.J. and the land. (276)

Cassie cries because T.J. has always been some minor part of her life and when he was nearly lynched that night, she understood what I've consistently asserted: that minor things can hold great power. As Cassie reflects here, this novel presents a critical reconfiguration of subjecthood in terms of her relationships to her family, her community, and the space they inhabit. Young Cassie's thoughtful meditations on those things that had happened and "would not pass" are productively situated within a tradition of work that is simultaneously theorized and embodied, taught and learned, folklore and powerful. It is from a similar exploration of the self in the face of oppression, a thoughtful consideration of minor political power, and a careful construction of 
a framework for understanding this power that I wish us to address pedagogical praxis and our ethical responsibilities to others, texts, and our students.

In a closing unit of one of my introductory African-American literature courses, which was heavily influenced by children's and adolescent literature, we focused on lynching narratives in broad and honest terms. Tyson's book is an in-depth exploration of Emmett Till's extrajudicial murder and the various factors that may have contributed to its great impact on the national discourses regarding race and racial injustice, but at its center, as a heavily publicized selling point, is the confession from Carolyn Bryant that she'd lied decades ago. Some students already knew much of this having followed the story fairly closely. Some students seemed offended but not surprised. Several other students responded in kind with their frustrations at the racial history of the United States and the relatively recent machinations of white supremacy. More than half a century seemed to fold onto itself like the third act of a horror film I thought was over already. So then, I posed a question to the class: what is a lynching? The answer wasn't singular or objective. It was a composite of hearsay, lore, and collaborative storytelling. The power of stories to uncover complex answers remains one of my largest takeaways from instructing this course. ${ }^{1}$

To be clear, it's not the answer itself but rather the effort students showed that remains with me as I reflect back on the experience. After developing a vocabulary throughout the semester, a unique rhythm and style consistent with the values of the discourse community we'd built, I felt students were able to engage with the subject in their own individual and collective ways. By this point, the obstacles of student presence and their completion of assigned readings

\footnotetext{
${ }^{1}$ IRB Project [1118593-2] Intersections of African-American Literature and Children's Literature - Jacques
} 
had been resolved, to a large extent, by time and the inertia of a long semester. Attendance had become, if not ideal, consistent, and students appeared more willing to embrace Tyson's book, which was admittedly one of the longest of the course, or at least jump into the conversations that emerged from it. Honestly, I think the obvious connections between Emmett Till and so many other young people that linger in the contemporary consciousness did more to invite discussion than anything in particular I could say or do. So again, I felt it necessary to remain silent, to listen, and witness the folklore of lynching - "as American as baseball," according to one student—come to fruition.

As the narrative manifested in real time, I tasked myself with thoughtfully framing it with selected materials and drawing connections, while students worked on filling in the frame organically. For example, we named the various overlapping stories at play when we unpacked Emmett Till's case- “The Story of the Boy Who Did the Talkin'," "The So-Called Trial," "The Story of a Mother," just to name a few—because, partly inspired by the \#sayhername movement contributed to heavily by feminist attorney Kimberlé Crenshaw, names have an undeniable power in these contexts. Likewise, in another attempt at transparency, I was grateful for the chance to link my background in children's literature to this framework by way of asking students to consider the audiences of these stories. I wanted my students to consider that there were certain stories that were disseminated at dinner tables, barbershop seats, and schoolyards throughout this country about how justice and safety can remain unattainable for some while the destruction of bodies of color can be perceived as swift and justified by too many others. I wanted my students to consider, borrowing from Seymour Chatman's theories of narrative, the implied reader as opposed to the real reader. "Not the flesh-and-bones you or I sitting in our living rooms reading the book," according to Chatman, "but the audience presupposed by the 
narrative itself' (149-50). I wanted them to see how a child's life could be violently undermined in a story intended to reinforce a timeless tale of white supremacy and inequity, but also how an open casket and a determined mother can tell a story of perseverance and longing for justice. I wanted the semester to end with my students understanding how much these stories mattered. If I was to be at all successful, I would be self-actualized as an instructor of literature. I would be satisfied with my teaching performance.

But in many ways, as with a majority of the courses in these early stages of my teaching career, I wasn't satisfied. Students didn't engage with assigned readings most of the time. Likewise, I think the number of absences left me with some what-ifs about how much I respect the potential of each and every student to contribute to a class. I hope, if anything, a minor lit pedagogy would figure out some way to not only communicate but convince students that their contributions are powerful in these spaces. Just as bell hooks affirms how "crucial" it is for “every student to be an active participant, not a passive consumer," I've become increasingly sensitive to how often active participation may not look like how we, as instructors, and they, as students, expect it to look (14). I observed this in the silences and in the voices of students who used their voices sparingly but effectively. I noticed this in the absences-several students had more than a dozen in a sixteen-week, Tuesday/Thursday course schedule - that were later explained as concerns about being prepared because the students hadn't done the readings for reasons I would never learn. And I saw this in the students who always seemed to ask the questions I thought I'd answered just a moment ago. I realize now that, just as I'd brought so many different texts and stories into the classroom, students often bring subtexts and historieseven those I find most difficult to reconcile with my own - that deserve consideration. And my desire for an inclusive class, focused on addressing inequity, is severely undermined if any 
student feels excluded from that work. To put it frankly, I just want to do good by my students. I earnestly believe it's a collaborative effort—of students, instructors, administrators, scholarsfolk, that is - to establish what good means in the context of learning. Essentially, when reflecting on how any opportunity to teach may not have happened at all if not for the willingness of others to take chances on my abilities, I'm admittedly humbled. Still, my ability to tell and "read" stories is my power and my responsibility, which I do not take lightly. 


\section{Conclusion}

Ultimately, the pedagogical efficacy of these stories relies on a complex understanding of their subjects. Just as students are subjects to both my instruction and terrible jokes in the classroom, both my teaching experience and the literary theories explored here would suggest that subjecthood remains most productively understood in a plurality of ways all at once. Chapter One broadly explores the subject(s) of children's and adolescent literature in regard to the genre's history in the United States following Stratemeyer's influence at the start of the twentieth century and the ideological interpellation of its target audience into subjects by the biases and prejudices of American culture. Chapter Two interprets this subjectification through a lens of political power and posits that special attention to minor subjects—as opposed to the dominant majority — is invaluable in addressing power inequity. This logic is expanded upon in Chapter Three's re-reading of Jacqueline Woodson's memoir and two of Toni Morrison's major literary works so to present them as representative examples of minor lit. Each novel reveals an intersectional relationship between sex, race, class, and adolescence; each story entangles the territory of adults and so-called "adult subjects" with that of young people in ways that inform both; and each text uses language aligned with the political realities of its young audience. Reconceptualizing the subjects of literary narratives while offering a framework for more equitable consideration of political subjecthood is decidedly the advantage of this theory of minor lit. Still, this conclusion acknowledges that, if anything can be certain, narratives and politics converge most readily in the classroom every day, alongside a wide range of academic subjects. Therefore, in a practical sense, uptake of the material of any subject wholly depends on the coexistence of divergent understandings of the term. 
Uptake, as a concept, has received increased attention from contemporary genre theorists and pedagogues precisely because it offers educators language to identify classroom convergences of texts, media, activities, etc. In this, I believe uptake may have been the source of my frustrations by the end of that introductory African-American literature course. How do you negotiate the convergence of wanting to do good as a teacher, having to do well as a student, more than two dozen embodied rhetorical styles, the Modern Language Association's expectations, the harrowing subject of racialized violence, and finite time? I do so with stories and, admittedly, uptake — my own and my students'—remains elusive. In Genre: An Introduction to History, Theory, Research, and Pedagogy (2010), Anis Bawarshi and Mary Jo Reiff define uptake as the "complex, often unconscious, transactions that mediate meanings and actions between genres" (653). It follows then that, as an educator, I'm a small part of this complicated activity system with an abundance of other moving parts—some of whom just happen to be tardy, absent, wholly unprepared for class, or ostensibly distracted by their devices. My curation of stories, assignments, and activities across genres (including but not limited to children's and adolescent literature at any opportunity) is nonetheless meaningful or at least notable in that it facilitates the discovery of meaning that remains largely subjective in more ways than one. Still, I am not a major component of the uptake machinery.

I'm minor.

As a key takeaway, I understand that to be powerful. 


\section{WORKS CITED}

Abate, Michelle Ann. Tomboys: A Literary and Cultural History. Temple Univ. Press, 2008.

Althusser, Louis. "Ideology and Ideological State Apparatuses." Lenin and Philosophy and Other Essays. Ben Brewster (Trans). (pp. 127-86). New York: Monthly Review, 1971.

“BANNED: The Bluest Eye.” PBS, Public Broadcasting Service, Sept. 2017.

Barnes, Riché J. D. "Policy Doesn't Help Us: Black Feminist Anthropology in the Social Work Classroom." Annals of Anthropological Practice, vol. 39, no. 2, 2015, pp. 134-149.

Bates, Clara Doty. Little Red Riding-Hood. D. Lothrop \& Co., 1883.

Baudrillard, Jean. The Consumer Society: Myths and Structures. Sage, 1998.

Bawarshi, Anis S., and Mary Jo Reiff. Genre: An Introduction to History, Theory, Research, and Pedagogy. Parlor Press, 2010.

Bishop, Rudine Sims. "Mirrors, Windows, and Sliding Glass Doors.” Perspectives, vol. 6, no. 3, 1990, pp. ix-xi.

---. "Reflections on the Development of African American Children's Literature." Journal of Children's Literature, vol. 38, no. 2, 2012, pp. 5-13.

Braidotti, Rosi. Metamorphoses: Towards a Materialist Theory of Becoming. Wiley, 2013.

Cadden, Mike. "The Irony of Narration in the Young Adult Novel.” Children's Literature Association Quarterly, vol. 25, no. 3, 2000, pp. 146-154.

Chatman, Seymour. Story and Discourse: Narrative Structure in Fiction and Film. Cornell Univ. Press, 2007.

Coats, Karen. Looking Glasses and Neverlands: Lacan, Desire, And Subjectivity in Children's Literature. Univ. of Iowa Press, 2004. 
---. “The Meaning of Children's Poetry: A Cognitive Approach.” International Research in Children's Literature, vol. 6, no. 2, 2013, pp. 127-142

The Combahee River Collective. “A Black Feminist Statement.” Women's Studies Quarterly, vol. 42, no. 3/4, 2014, pp. 271-80.

Connolly, Paula T. Slavery in American Children's Literature, 1790-2010. Univ. of Iowa Press, 2013.

Copjec, Joan. "The Orthopsychic Subject: Film Theory and the Reception of Lacan.” October, vol. 49, 1989, pp. 53-71.

Davis, Angela Yvonne. Women, Race \& Class. Vintage Books, 1986.

Deleuze, Gilles, and Felix Guattari. Kafka: Toward a Minor Literature. Univ. of Minnesota Press, 2012.

---. A Thousand Plateaus. Berkeley, CA: Venus Pencils, 2009.

---. Anti-Oedipus: Capitalism and Schizophrenia. Univ. of Minnesota Press, 1983.

Deleuze, Gilles, et al. "What Is a Minor Literature?” Mississippi Review, vol. 11, no. 3, 1983, pp. $13-33$.

Douglass, Frederick. My Bondage and My Freedom. Modern Library, 2007.

---. Narrative of the life of Frederick Douglass, an American slave. G. Kershaw and Son, 1852.

---. The Life and Times of Frederick Douglass: His Early Life as a Slave, His Escape from Bondage, and His Complete History. Dover Publications, 2003.

Dundes, Alan. "The American Concept of Folklore.” Journal of the Folklore Institute, vol. 3, no. 3, 1966, pp. 226-49.

Eckert, Penelope. "Adolescent Language." Language in the USA, edited by Charles Albert Ferguson et al., Cambridge Univ. Press, 2009, pp. 361-74. 
Emrich, Duncan. “'Folk-Lore’: William John Thoms.” California Folklore Quarterly, vol. 5, no. 4, 1946, pp. 355-74.

Equal Justice Initiative. "Lynching in America: Confronting the Legacy of Racial Terror.” 2017, lynchinginamerica.eji.org/.

“Frequently Challenged Books.” American Library Association, March 26, 2013. http://www.ala.org/advocacy/bbooks/frequentlychallengedbooks

Gates, Henry Louis. The Signifying Monkey: a Theory of Afro-American Literary Criticism. 1988. Oxford Univ. Press, 2014.

Genette, Gérard. Narrative Discourse: an Essay in Method. Cornell Univ. Press, 1990.

Heiner, Heidi Anne. "The Annotated Little Red Riding Hood." SurLaLune Fairy Tales: The Annotated Little Red Riding Hood, Jan. 1999, www.surlalunefairytales.com/ridinghood/index.html.

hooks, bell. "Postmodern Blackness." Theorizing Feminisms: A Reader. Ed. Elizabeth Hackett and Sally Anne. Haslanger. Oxford Univ. Press, 2006. 363-68.

---. Teaching to Transgress. Routledge, 2014.

Hope, Laura Lee. The Outdoor Girls of Deepdale, Or, Camping and Tramping for Fun and Health. New York: Grosset \& Dunlap, 1913.

Jones, Leisha. "Contemporary Bildungsromans and the Prosumer Girl." Criticism 53.3 (2011): 439-69. Project MUSE. Web. 27 Oct. 2015.

Kafka, Franz. The Metamorphosis. Translated by David Wyllie, Classix Press, 2009.

Karenga, Ron. "Black Cultural Nationalism.” The Black Aesthetic, edited by Addison Jr. Gayle, Garden City, 1972, pp. 31-37.

King, I. Marlene. "The Lady Killer.” Pretty Little Liars. ABC Family. 28 Aug. 2012. Television. 
---. “Single Fright Female.” Pretty Little Liars. ABC Family. 21 Aug. 2012. Television.

Lacan, Jacques. Ecrits: The First Complete Edition in English. Trans. 1966. Bruce Fink. New York: Norton, 2007.

Lamarque, Peter. Fictional Points of View. Cornell Univ. Press, 1996.

Lorde, Audre. "Poetry Is Not a Luxury.” Poetry and Cultural Studies: a Reader, by Maria Damon and Ira Livingston, Univ. of Illinois Press, 2009, pp. 355-58.

Morgan, Joan. "Why We Get Off: Moving Towards a Black Feminist Politics of Pleasure.” The Black Scholar, vol. 45, no. 4, 2015, pp. 36-46

Morrison, Toni. The Bluest Eye. 1970. New York: Vintage, 2016.

---. Sula. 1973. Vintage, 2016.

Nikolajeva, Maria. The Rhetoric of Character in Children's Literature. Scarecrow Press, 2002.

---. "Theory, Post-Theory, and Aetonormative Theory." Neohelicon, vol. 36, no. 1, 2009, pp. 1324.

Nodelman, Perry. The Hidden Adult: Defining Children's Literature. Johns Hopkins UP, 2008.

---. "The Other: Orientalism, Colonialism, and Children's Literature." Children's Literature Association Quarterly, vol. 17, no. 1, 1992, pp. 29-35.

Perrault, Charles L. Edited by D. L. Ashliman, Little Red Riding Hood: and Other Tales of Aarne-Thompson-Uther Type 333, 8 Apr. 2018, www.pitt.edu/ dash/type0333.html.

Rehak, Melanie. Girl Sleuth: Nancy Drew and the Women Who Created Her. Thorndike, 2006.

Salinger, J. D. The Catcher in the Rye. Little, Brown and Company, 1951.

Saul, Wendy, and Kendra Wallace. "Centering the Margins: White Preservice Teachers' Responses to Roll of Thunder.” Teaching Education, vol. 13, no. 1, Apr. 2002, pp. 41-53. Shepard, Sara. Pretty Little Liars. New York, NY: Harper Teen, 2007. 
Soderbergh, Peter A. "The Stratemeyer Strain: Educators the Juvenile Series Book, 19001973. The Journal of Popular Culture vol. 7, no. 4, 1974, pp. 864-72.

Tatar, Maria. The Hard Facts of the Grimms Fairy Tales. Princeton Univ. Press, 2019.

Taylor, Mildred D. 1976. Roll of Thunder, Hear My Cry. Vol. 2. Penguin, 1997.

Till-Mobley, Mamie, et al. Death of Innocence: The Story of the Hate Crime that Changed America. Random House Publishing Group, 2011.

Tolkien, J. R. R. “On Fairy-Stories.” Essays Presented to Charles Williams. Ed. C. S. Lewis. Grand Rapids, MI: William B. Eerdmans, 1966.

Tolson, Nancy D. Black Children's Literature Got De Blues: The Creativity of Black Writers \& Illustrators. Peter Lang, 2008.

Touponce, William F. "Children's Literature and the Pleasures of the Text." Children's Literature Association Quarterly, vol. 20, no. 4, 1995, pp. 175-82.

Trites, Roberta Seelinger. Disturbing the Universe: Power and Repression in Adolescent Literature. Univ. of Iowa Press, 2000.

---. "The Paradox of Authority in Adolescent Literature." Disturbing the Universe: Power and Repression in Adolescent Literature. Univ. of Iowa Press, 2000. pp. 54-83

Tyson, Timothy B. The Blood of Emmett Till. Simon \& Schuster, 2017.

Watson, Bruce. "Tom Swift, Nancy Drew and Pals All Had the Same Dad." Smithsonian, vol. 22, no. 7, Oct. 1991, p. 50 .

Wells-Barnett, Ida B., et al. Crusade for Justice: the Autobiography of Ida B. Wells. Univ. of Chicago Press, 2020.

Wilhelm, Jeffery. “Literary Theorists, Hear My Cry!” English Journal-Illinois, vol. 81, Nov. 1992, p. 50-56. 
Wood, Amy Louise. Lynching and Spectacle: Witnessing Racial Violence in America ; 18901940. Univ. of North Carolina Press, 2011.

Woodson, Jacqueline. Brown Girl Dreaming. Penguin, 2014. Print.

Yazdanjoo, Morteza, et al. 'Stylistic Features of Holden Caulfield's Language in J. D. Salinger's The Catcher in the Rye: A Corpus-Based Study.” English Studies, vol. 97, no. 7, 2016, pp. 763-78.

Žižek, Slavoj. Looking Awry: An Introduction to Jacques Lacan through Popular Culture. MIT, 1991. 